\title{
A véleményszabadság alkotmányos védelme az Alaptörvény első évtizedében
}

\section{KOLTAY ANDRÁS ${ }^{1}$}

Az áttekintés a magyar Alkotmánybíróság véleményszabadsággal összefüggö gyakorlatának változásait követi nyomon az Alaptörvény hatálya alatt, azaz a 2012. január 1-je óta született határozatok fényében. Következtetése szerint a kisebb-nagyobb következetlenségek ellenére a vizsgált évek alatt jelentös elörelépés történt a véleményszabadság alkotmányos tartalmának meghatározásában. A közügyek vitái úgy maradtak széles körben szabadok, hogy közben az emberi méltóság sem maradt védtelen. A bíróságok több esetkör - elsösorban a személyiségi jogok védelme - tekintetében világos mércéket kaptak, és a gyakorlat olyan kérdéseket is érint, mint a híresztelés vagy a képmásvédelem, amelyekről korábban az AB nem szólhatott.

Kulcsszavak: véleményszabadság, sajtószabadság, hírnév- és becsületvédelem, magánélet védelme, gyülöletbeszéd

\section{The Constitutional Protection of Freedom of Expression in the first Decade of the Fundamental Law of Hungary}

The overview traces the changes in the Hungarian Constitutional Court's jurisprudence in the context of freedom of expression under the now decadeold Fundamental Law, that is, in the light of the decisions adopted since 1 January 2012. It concludes that, despite some inconsistencies, significant progress has been made in defining the scope and limits of freedom of expression over the years under review. Public debates have remained widely protected, while human dignity has not been left defenceless. The courts have been given clear standards in a number of areas, in particular the protection of personality rights, and the case law has extended to issues such as press reports or the protection of image rights, which were previously excluded from the jurisdiction of the Constitutional Court.

Keywords: freedom of expression, freedom of the press, protection of reputation and honour, privacy, hate speech

1 Rektor, egyetemi tanár, Nemzeti Közszolgálati Egyetem és egyetemi tanár, Pázmány Péter Katolikus Egyetem, e-mail: Koltay.Andras@uni-nke.hu

A szerző köszöni Reményi Édua szerkesztői segítségét, valamint Szikora Tamás, Szomora Zsolt, Téglási András, Török Bernát és Udvari Erzsébet Xénia szakértő megjegyzéseit, amelyeket a kézirat korábbi változatához füztek. 


\section{Bevezető megjegyzések}

A következőkben az Alkotmánybíróság $(\mathrm{AB})$ véleményszabadsággal összefüggő gyakorlatának változásait kívánjuk nyomon követni az Alaptörvény hatálya alatt, azaz a 2012. január 1-je óta született határozatok fényében. Az AB gyakorlata természetesen csak az egyik fontos tényező a véleményszabadság jogi határainak azonosításában - legyen mégoly fontos is -, de önmagában is sokat elárul egy állam alkotmányos kultúrájáról, jogrendszere felfogásáról az alapjogok tekintetében, és képes befolyásolni mind a jogalkotást, mind pedig a bíróságok általi jogalkalmazást.

Ez utóbbira az AB-nak az Alaptörvény hatálya alatt jóval nagyobb lehetősége van: a valódi alkotmányjogi panasz bevezetése nyomán az $\mathrm{AB}$ felülvizsgálja az egyedi bírói döntéseknek az Alaptörvénnyel való összhangját. ${ }^{2}$ Az új hatáskör bevezetéséből egyes területeken az $\mathrm{AB}$ esetjogának expanzív gyarapodása következett, így számos olyan kérdés is a testület elé került, amelyet korábban absztrakt normakontroll keretében nem vizsgálhatott. $A z A B$ hatásköre mindazonáltal nem a vizsgált bírósági döntések „helyességére”, hanem az azok által a döntés során alkalmazott szempontrendszer alkotmányos megfelelőségére terjed ki; $\mathrm{az} A \mathrm{~B}$ tehát nem újabb fellebbezési fórum, hanem az Alaptörvény által megkövetelt bírói mérlegelés őre. A később tárgyalt egyes határozatok némelyikének indokolása megmutatja, milyen nehéz ezen a vékony pallón végigmenni, ügyelve arra, hogy a testület csak a döntés alkotmányos kereteit szabja meg a bíróságok számára, meghagyva számukra a tényállás sajátosságaiból fakadó mérlegelés lehetőségét, és ne döntse el helyettük az adott ügyet.

Fontos, hogy az Alaptörvény csak részleges cezúrát jelentett az alkotmányos gyakorlat számára, és a 13/2013. (VI. 17.) AB határozat nyomán az Alaptörvény szerint hatályukat vesztett korábbi $\mathrm{AB}$ határozatok is irányadók maradhatnak az Alaptörvény hatálya alatt is, ha az Alaptörvény érintett rendelkezése az előző Alkotmányban foglaltakkal azonos vagy hasonló tartalmú, és a korábbi határozatban foglalt érvek, jogelvek és alkotmányossági összefüggések felhasználását a testület kellő részletességgel indokolja. ${ }^{3} \mathrm{~A}$ jelen áttekintésben azonban csak a legindokoltabb esetben hivatkozunk 2012 előtti $\mathrm{AB}$-döntésre, akkor, ha az újabb döntések előidézte változások megértéséhez az szükséges. Áttekintésünk nem törekedhet a teljességre; a választási kampányidőszakban speciális eljárásban született döntések jó részét - bár nem mindegyikét - például figyelmen kívül hagyjuk, ${ }^{4}$ de ezzel együtt is alapos és átfogó képet próbálunk adni az $\mathrm{AB}$ véleményszabadsághoz kapcsolódó gyakorlatáról. Vezérfonalunk, amelyhez e gyakorlatot mérni igyekszünk, a nyilvános kommunikáció szabadsága és az általa megsérteni képes emberi méltóság védelme közötti egyensúly

2 Magyarország Alaptörvénye 24. cikk (2) bekezdés $d$ ) pont.

3 13/2013. (VI. 17.) AB határozat [28]-[34] bek.

4 Azokra nézve lásd Badó Katalin - Lovassy Ádám - Téglási András: Az Alkotmánybíróság választásokkal kapcsolatos joggyakorlata (1990-2017). In Téglási András (szerk.): Tanulmányok a választójog, a választási rendszerek és a népszavazás aktuális kérdéseiröl. A Választás és Demokrácia Ludovika Kutatócsoport kutatási eredményei (2017-2018). Budapest, Dialóg Campus, 2019. 303-470. 
megtalálásának célkitüzése. Hiú ábránd ez, hiszen az egyes ügyek esetében - mivel azokat el kell dönteni - ilyen egyensúly fogalmilag nem létezhet: vagy a szabadság, vagy a méltóság védelme kerekedik felül. De összességében, a joggyakorlat egésze törekedhet arra, hogy a két versengő érték között egyensúlyt keressen, egyszerre biztosítva mindkettőt és korlátozva érvényesülésüket. Az áttekintés végére reményeink szerint képet kapunk arról, hogy ez a zsonglőrmutatvány - amelynek kivitelezését az $\mathrm{AB}$ a feladatául kapta - az eddigiekben mennyire volt sikeres.

\section{Az Alaptörvény IX. cikke}

Az Alaptörvény IX. cikk (1) és (2) bekezdései rendelkeznek a vélemény és a sajtó szabadságáról, a jelenlegi (6) - elfogadáskori (3) - bekezdés pedig az egyes kapcsolódó szabályozási tárgykörök sarkalatos jellegéről. Ha a 2010 nyara előtti Alkotmány 61. $\mathbb{\$}$-ával vetjük össze e rendelkezéseket, akkor lényeges különbségeket fedezhetünk fel, de ha a IX. cikket a 2010 nyara és 2012. január 1. közötti másfél év alatt hatályos normaszöveggel hasonlítjuk össze, akkor az eltérések már nem annyira szembeötlők. A sajtó sokszínűsége és a demokratikus közvélemény szabad tájékoztatásának biztosítása a sajtószabadság vonatkozásában 2010 nyara óta az állami szervek többletkötelezettségeként jelenik meg az alkotmányszövegekben. ${ }^{5}$

Az Alaptörvény IX. cikk jelenlegi (3)-(5) bekezdései utólag, 2013-ban kerültek a szövegbe, és egyedi törvényalkotási igények alkotmányos alátámasztását szolgálják, emiatt általános érvénnyel nem is hatnak ki a véleményszabadság értelmezésére. A (3) bekezdés a politikai reklámok választási kampányidőszakban való és ingyenes közléséről rendelkezik, a (4) bekezdés rögzíti, hogy a véleményszabadság gyakorlása nem célozhatja az emberi méltóság megsértését, az (5) bekezdés pedig a meghatározott közösségeket érő gyülölködő véleményekkel szembeni magánjogi igényérvényesítés útját kívánja alkotmányosan megalapozni.

Míg a (3) bekezdés a választási eljárásról szóló, az Országgyűlés által 2012. november 26-án elfogadott törvény előzetes normakontrollja során az 1/2013. (I. 7.) $\mathrm{AB}$ határozattal megsemmisített, a politikai reklámokra vonatkozó szabályra, addig a (4)-(5) bekezdések a gyülöletbeszéddel kapcsolatos korábbi AB-gyakorlatra adott reflexióknak tekinthetők, illetve a (4) bekezdésben rögzített méltóságvédelmi szabály a személyiségi jogi relevanciájú ügyekben is irányadó. De, amint Szomora Zsolt utal rá az 1/2015. (I. 16.) AB határozat kapcsán, a véleményszabadság és a méltóságvédelem közötti mérlegelés eredménye az AB korábbi gyakorlatából fakadóan a IX. cikk (4) bekezdése nélkül is ugyanaz lehet, mint az új alkotmányszöveg mellett ${ }^{6}$ - ezen észrevétele pedig megítélésünk szerint általános érvényủ, túlmutat az általa elemzett

5 Lásd: Koltay András: Az Alkotmány új 61. \$-a. A vélemény- és a sajtószabadság új ruhában. Közjogi Szemle, (2010), 3. 1-9.

6 Szomora Zsolt: A véleményszabadság büntetőjogi korlátai az Alaptörvény hatályba lépése után, különös tekintettel a becsületvédelemre. In Balogh Elemér (szerk.): Számadás az Alaptörvényröl. Budapest, Magyar Közlöny Lap- és Könyvkiadó, 2016. 535. 
döntésen. Az (5) bekezdés egyértelmüen a szintén 2013-ban elfogadott Ptk. rendelkezéseinek alkotmányos alátámasztására szolgál.7 Összességében kérdés - amelynek megválaszolásához talán közelebb kerülhetünk a továbbiakban -, hogy az Alaptörvény szövege mennyiben befolyásolja az AB gyakorlatát vagy tágabban, a joggyakorlatot.

\section{A véleményszabadság hatálya és védelme}

Az újabb alkotmánybírósági gyakorlat fontos elemei a véleményszabadság hatályának kérdését feszegető döntések. ${ }^{8} \mathrm{~A}$ jogrendszernek különbséget kell tennie a véleményszabadság hatályának (hatókörének) terjedelme és a hatálya alá tartozó beszéd védelmének ereje között. Amely kifejezés vagy tett kívül reked a véleményszabadság hatályán, azzal kapcsolatban az alkotmányos védelem lehetősége fel sem merül. Ha ellenben egy megnyilvánulás a hatálya alá tartozik, annak vonatkozásában vizsgálni lehet, hogy az alapjog alkotmányos védelme kiterjed-e rá. A véleményszabadság korlátainak meghatározása csak az alapjog gyakorlásának minősülő esetek összefüggésében értelmezhető.

A 3132/2018. (IV. 19.) AB határozat rögzítette, hogy a rongálás vétségét megvalósító magatartás is a véleményszabadság körébe vonható. Az indítványozó a budapesti Szabadság téren emelt német megszállási emlékmű mellett álló, a szobor felállításán dolgozó építőipari cég tulajdonában álló ponyvára festett rá, mindez „az indítványozó azon véleményét közvetítette, hogy nem ért egyet az említett emlékmủ felállításával". A testület szerint azonban a cég tulajdonjogának védelme a konkrét esetben alapot ad a véleményszabadság korlátozására, azzal együtt is, hogy ez utóbbi közügyet érintett. $^{10}$

Az AB 1/2019. (II. 13.) AB határozatában a véleményszabadság hatályán kívül esőnek tekintette ugyanakkor a szintén Szabadság téri szovjet hősi emlékmủ festékkel való leöntését. A cselekedetet egy jogszerü tüntetés után követték el, azzal vélhetöen a magyar és az orosz kormányzat tárgyalásaival, közeledésével szemben kívántak tiltakozni. A kétségtelenül expresszív jelleget is hordozó magatartás megítélésének bizonytalansága azonban alapot adott arra, hogy a testület azt a véleményszabadság körén kívül esőnek minősítse. ${ }^{11} \mathrm{Az} \mathrm{AB}$ e döntésében fontos megállapításokat tett a véleményszabadság hatályával kapcsolatban - ezek a következőképpen összegezhetők:

7 Háttéranyag az Alaptörvény negyedik módositásához. é. n. 18-19.

8 A 2018 előtti AB-gyakorlat elemzéséről Lásd: Török Bernát: A közlések alkotmányos alapértéke a szólásszabadság magyar koncepciójában. In Koltay András - Török Bernát (szerk.): Sajtószabadság és médiajog a 21. század elején 2. Budapest, Wolters Kluwer, 2015. 203-224.

9 3132/2018. (IV. 19.) AB határozat [36] bek.

10 3132/2018. (IV. 19.) AB határozat [39]-[42] bek.

11 1/2019. (II. 13.) AB határozat [44]-[45] bek. 
- a véleményszabadság csak a nyilvánosságnak szánt közlésekre terjedhet ki; ${ }^{12}$

- tettleges - azaz nem szavakban kifejezett - megnyilvánulás is lehet véleménynyilvánítás ${ }^{13}$

- a véleményszabadság körébe nem a köznapi értelemben vett megszólalások tartoznak, hanem azt kell vizsgálni, hogy mely aktusok állnak kapcsolatban az alapjog alkotmányos igazolásával, az önkifejezés és a demokratikus nyilvánosság értékeivel; ${ }^{14}$

- a cselekményt elkövető a véleménye kifejezése céljából cselekedjen; ${ }^{15}$

- „a közlés választott formája objektív módon is alkalmasnak tekinthető eszköze, közvetítője legyen gondolatok közlésének"; ${ }^{16}$

- a cselekedet „a nyilvánosság előtt értelmezhető közlés” legyen, azaz a nyilvánosság tagjai értsék, hogy vélemény közlését valósítja meg. ${ }^{17}$

A fenti kritériumlista jelentős elörelépés a véleményszabadság körvonalaira vonatkozó fogalmi tisztázáshoz, két eleme azonban vitatható. Egyrészt nem vagyunk biztosak abban, hogy a véleményszabadság valóban csak a nyilvánosság előtt tett közléseket védi, ilyen megszorítás nem következik az Alaptörvényből. Egy magánlevélben is szerepelhet, vagy szűk körű beszélgetésen is elhangozhat védett vélemény. Másrészt bár az $\mathrm{AB}$-döntés indokolása nem rögzíti e kérdésben alkotott álláspontját teljes pontossággal, arra lehet belőle következtetni, hogy a testület csak azon megnyilvánulást tekinti a véleményszabadság körébe tartozónak, amely nem csupán véleményként azonosítható, hanem amelynek tartalmát, mondanivalóját azok, akik azt érzékelik, értik is. Az AB az irányadó alkotmányos szempontrendszerrel összhangban állónak ítélte meg az ügyben korábban eljárt másodfokú bíróság jogértelmezését, ${ }^{18} \mathrm{a}$ bíróság pedig világossá tette, hogy azért nem tekinti az emlékmü leöntését a véleményszabadság körébe tartozónak, mert szükségesnek tartja, hogy az azt észlelők számára annak jelentése, motivációja, célja értelmezhető legyen. ${ }^{19}$ Megítélésem szerint ez tévedés. Számos példát lehetne hozni a művészet- és az irodalomtörténetből a kortárs közönség értetlenkedésére, a műalkotások vagy irodalmi művek jelentésének, üzenetének befogadásával kapcsolatos problémákra. ${ }^{20} \mathrm{~A}$ véleményszabadság hatálya alá vonáshoz elegendőnek tűnik, hogy egy magatartás véleményként értelmezhető legyen, a véle-

12 1/2019. (II. 13.) AB határozat [29] bek.

13 1/2019. (II. 13.) AB határozat [30] bek.

14 1/2019. (II. 13.) AB határozat [31] bek.

15 1/2019. (II. 13.) AB határozat [36] bek.

16 1/2019. (II. 13.) AB határozat [36] bek.

17 1/2019. (II. 13.) AB határozat [44] bek.

18 1/2019. (II. 13.) AB határozat [45] bek.

19 1/2019. (II. 13.) AB határozat [5] bek.

20 A művészet és a véleménynyilvánítás szabadságának terjedelmét pedig - dacára az Alaptörvényben történő önálló nevesítésüknek - a magyar jogrendszerben azonosnak tekintem, a példa ezért lehet találó. Erre nézve lásd: Koltay András: Dorian Gray képmásához való jog: a művészet szabadságának önálló alapjogi jellegéről. In Koltay András - Török Bernát (szerk.): Sajtószabadság és médiajog a 21. század elején 3. Budapest, Wolters Kluwer, 2016. 53-99. 
mény tartalmának megértése ahhoz nem szükséges. A konkrét ügyben nem vitatható, hogy a tüntető valamit ki akart fejezni, még ha nem is egészen érthető, hogy mit. Ezzel együtt az emlékműhöz füződő tulajdon- és kegyeleti jogok védelme még a véleményszabadság hatályán belül értelmezett cselekedettel szemben is alapot adhatnak a korlátozásra. ${ }^{21}$

A 14/2019. (IV. 17.) AB határozat szerint viszont a közterületnek minősülő útvagy járdaszakaszon könnyen eltávolítható festékkel elhelyezett feliratok, színezések minősülhetnek a véleménynyilvánítás jogának hatálya alá eső megnyilvánulásnak. A festést egy ellenzéki politikai párt követte el, a járda elhanyagolt állapota elleni tiltakozásul. „A konkrét cselekmény tehát az objektív értékelés szerint a nyilvánosság számára értelmezhető közlés volt." A testület többsége egy fontos kiegészítő szemponttal is gazdagította a véleményszabadság alkotmányos gyakorlatát: mint az indokolás említi, „a cselekmény megítélésekor az eljáró szervek józan humorérzékére is szükség van"22 - ezzel mélyen egyetérthetünk.

A 3089/2019. (IV. 26.) AB határozat szintén a véleményszabadság hatókörét érintette. Az indítványozók több bank ügyfélterében helyeztek el egy-egy kisebb, papírba csomagolt fahasábot, amelynek egyik oldalára az „Elég volt a kifosztásból! Fordíts!” szöveget, míg a másik oldalára Petőfi Sándor Föltámadott a tenger címü versének egy részletét írták (a vers szövege csak akkor vált láthatóvá, ha a csomagot valaki felvette és megfordította). Az AB ezt a tettet a véleményszabadság körébe tartozónak tekintette. ${ }^{23} \mathrm{~A}$ bankban jelen lévők a letett fadarabokat robbanóanyagnak nézhették, így a cselekedet a bíróságok közveszéllyel fenyegetésnek minősítették. A véleményszabadság védelmének kérdésében $\mathrm{az} A \mathrm{~A}$ döntésének indokolása kissé félreérthető. A testület szerint „bár az indítványozók cselekményének volt azonosítható kommunikációs üzenete, az összességében mégsem tekinthető védett alapjog-gyakorlásnak, mivel az indítványozók [...] cselekményének kommunikációs üzenete azért nem volt azonosítható a külső szemlélő számára, mivel a vizsgált cselekmény sértette a közbiztonság fenntartásának alkotmányosan védett értékét". ${ }^{24}$ Ebből az következik, hogy a cselekmény véleményjellege nem volt a jelenlévők számára értelmezhető, azaz a 1/2019. (II. 13.) AB határozat logikája szerint az nem minősülhetett volna a véleményszabadság körébe tartozónak. Sőt, az újabb ügyben vizsgált magatartás rögtön két, a korábbi döntésből levezethető kritériumot sem teljesített: nem volt véleményként értelmezhető, ezzel összefüggésben pedig értelemszerủen a vélemény tartalmát sem érthették a jelenlévők. Ezt az ellentmondást a későbbi határozatokban majd tisztázni szükséges. Megítélésem szerint az előbbi két kritériumból csak az egyik megléte

21 A határozat elemzését lásd: Mészáros Ádám Zoltán: Szimbolikus szólás kontra dologrongálás. Azaz a véleménynyilvánítás szabadsága és a tulajdonhoz való jog határvitája büntetőjogi szempontból. Jogtudományi Közlöny, 75. (2020), 2. 74-78.

22 14/2019. (IV. 17.) AB határozat [36] bek.

23 3089/2019. (IV. 26.) AB határozat [32] bek.

24 3089/2019. (IV. 26.) AB határozat [38] bek. 
szükségtelen a véleményszabadság hatálya alá kerüléshez: a véleményjelleg érzékelése fontos, de a vélemény tartalmának megértése már nem.

\section{Személyiségvédelem és a közügyek vitái}

A személyiségi jogok védelmének terjedelme $\mathrm{az} A B$ gyakorlatában - a valódi alkotmányjogi panasz lehetőségének köszönhetően - a leggyakrabban felmerülő olyan problematika, amely a véleményszabadság határait érinti. A kérdéskör komplex: magánjogi és büntetőjogi eljárások útján is az $\mathrm{AB}$ elé kerülhetnek vitás kérdések, mindkét jogágban többféle tényállás alkalmazása nyomán, ráadásul két új kódex is született, illetve lépett hatályba a tárgyalt időszakban.

\subsection{Az új jogági kódexek rendelkezései}

Az Alaptörvény - a korábbi Alkotmányhoz hasonlóan - nemcsak a véleménynyilvánítás szabadságát, hanem a jó hírnév és a magánélet védelmét is alapvető jogként tételezi. Az ezt rögzítő VI. cikk (1) bekezdése azonban második mondatában 2018 óta a korábbinál határozottabb megfogalmazást tartalmaz: „Mindenkinek joga van ahhoz, hogy magán- és családi életét, otthonát, kapcsolattartását és jó hírnevét tiszteletben tartsák. A véleménynyilvánítás szabadsága és a gyülekezési jog gyakorlása nem járhat mások magán- és családi életének, valamint otthonának sérelmével." Egyelőre e rendelkezés még nem idézett elő módosulást az $A B$ személyiségi jogokat érintő gyakorlatában, ahogyan a 2012 óta megszületett két új jogági kódex által bevezetett jogszabályváltozások hatása is csekélynek nevezhető. A Büntető törvénykönyvről szóló 2012. évi C. törvény (Btk.) rágalmazást és becsületsértést tiltó tényállásait ${ }^{25} \mathrm{a}$ kódex a régi Btk.-ból szöveghủen átvette. ${ }^{26} \mathrm{~A}$ Polgári törvénykönyvről szóló 2013. évi V. törvény (Ptk.) - 1959-es elődjével ellentétben - magában foglalja a becsülethez való jog megsértésének a joggyakorlatban kikristályosodott tényállását, ${ }^{27}$ illetve kisebb mértékben módosította a képmásvédelem szabályait is ${ }^{28}$ Érdemi változást jelent a magánjogi kódexben a magánélethez való jog nevesített védelme, ${ }^{29}$ valamint a 2:44. \$-ban található, a közügyek vitáinak szabadságának biztosítását, egyúttal a közéleti szereplők személyiségi jogai védelmének szűkítését célzó generálklauzula. Ez utóbbival kapcsolatban született meg a későbbi AB-gyakorlat számára kulcsfontosságú 7/2014. (III. 7.) $\mathrm{AB}$ határozat.

A Ptk. 2:44. \$-a a kódex elfogadásakor így szólt: „A közügyek szabad vitatását biztosító alapjogok gyakorlása a közéleti szereplő személyiségi jogainak védelmét

25 Btk. 226-227. §.

26 A rágalmazás és becsületsértés tényállásainak átfogó és összehasonlító elemzését lásd: Tóth J. Zoltán: A büntetőjogi rágalmazás és becsületsértés. Budapest, Médiatudományi Intézet, 2017.

27 Ptk. 2:45. \$(1) bek.

28 Ptk. 2:48. $\$$.

29 Ptk. 2:43. $₫$ b) pont. 
méltányolható közérdekből, szükséges és arányos mértékben, az emberi méltóság sérelme nélkül korlátozhatja." A normaszövegben szereplö, a csökkentett személyiségvédelem egyik feltételeként meghatározott „méltányolható közérdek” szövegrészt az Alapvető Jogok Biztosa a rendelkezés hatálybalépése előtt alkotmánybírósági indítványban támadta meg. Ezt követően az $\mathrm{AB}$ a 7/2014. (III. 7.) $\mathrm{AB}$ határozatával megsemmisítette az érintett szövegrészt. Az emberi méltóság védelmével kapcsolatban a határozat megállapította, hogy az a véleményszabadság korlátja lehet, de bármely sérelme „nem igazolhatja a véleményszabadság korlátozását. Ellenkező esetben a véleményszabadság tartalma kiüresedne. [...] Az emberi méltóság védelméhez való jog csak az emberi státusz jogi meghatározójaként korlátozhatatlan.”30

$\mathrm{Az}$ alkotmányos probléma és az $\mathrm{AB}$ számára rendelkezésre álló nem túl széles mezsgye könnyedén azonosítható. Az Alaptörvény II. cikke és a Ptk. 2:42. $\mathbb{S}(2)$ bekezdése kifejezetten védi az emberi méltóságot, az előbbi annak sérthetetlenségét is kinyilvánítja, ami azonban nem jelent korlátozhatatlanságot is. A véleményszabadság az emberi méltósághoz hasonlóan alkotmányos jog, amely szintén nem korlátozhatatlan, de korlátozása - hasonlóan minden más alapjoghoz - csak szűk körben lehetséges.

Az emberi méltóság és a véleményszabadság alkotmányos kollíziója nem új keletű probléma. A Ptk. 2:44. \$-a úgy kíván többletvédelmet nyújtani a véleményszabadságnak - a közügyek vitatásának szélesebb körét biztosítva -, hogy egyúttal (a szélesebb védelem egyik objektív korlátjaként) megtiltja az emberi méltóságot sértő vélemények közzétételét. Ennek megfelelően, ha azt feltételezzük, hogy ez utóbbi rendelkezés nem lehetetlenítheti el a véleményszabadság gyakorlását - hiszen bármely sérelmes vélemény szükségszerüen egyben az emberi méltóságot is sértheti, így elvben szankcionálható lenne -, akkor az emberi méltóság védelmének a vizsgált rendelkezés alkalmazása tekintetében olyan alkotmányos értelmezést kell adni, amely útmutatásul szolgálhat a jogalkalmazás számára is. ${ }^{31}$

A döntés leszögezi, hogy az „emberi méltóság korlátozhatatlan aspektusa csak az emberi státuszt alapjaiban tagadó véleménynyilvánítások egészen szűk körében jelenti a véleményszabadság abszolút határát".32 A vélemények, értékítéletek - föszabály szerint - nemcsak a büntető, hanem a polgári jogi felelősségre vonásnak sem lehetnek az alapjai; e tekintetben a határozat visszautal a 36/1994. (VI. 24.) AB határozat egyik leglényegesebb elemére, a becsületsértő vélemények teljes büntetlenségének követelményére. De, ellentétben az 1994-es döntéssel, a testület 2014-ben nem tekintette ezen értékítéleteket minden esetben alkotmányosan védettnek. Mint az indokolás rögzíti, a közügyek nyílt vitatásának biztosítása:

30 7/2014. (III. 7.) AB határozat [43] bek.

31 Lásd: Koltay András: Az „általános személyiségi jog” azonosítása felé. Alkotmányjogi, magánjogi és büntetőjogi vizsgálódás. In Koltay András - Török Bernát (szerk.): Sajtószabadság és médiajog a 21. század elején 4. Budapest, Wolters Kluwer, 2017. 267-296. 
„Nem jár az érintettek emberi méltósága, magánélete és jó hírneve védelmének [...] kiüresedésével. A közhatalmat gyakorló személyeket és a közszereplő politikusokat is megilleti a személyiségvédelem, ha az értékítélet a személyüket nem a közügyek vitatása körében, nem közéleti tevékenységükkel, hanem magán- vagy családi életükkel kapcsolatban érinti. Indokolt lehet a polgári jogi felelősségre vonás abban a szűk körben is, amikor a megfogalmazott vélemény az érintett személy emberi státuszának teljes, nyilvánvaló és súlyosan becsmérlő tagadásaként már nem az új Ptk. 2:43. \$-ában foglalt nevesített személyiségi jogokba, hanem a 2:42. $\mathbb{S}$-ban foglalt emberi méltóság korlátozhatatlan aspektusába ütközik. A korábban kifejtettek figyelembevétele mellett továbbá a közéleti szereplők is igényelhetnek jogi védelmet a hamis tényállításokkal szemben." ${ }^{33}$

Ezzel a testület választ ad arra a kérdésre is, hogy miként kell értelmezni alkotmányos szempontból az Alaptörvény IX. cikk (4) bekezdését, amely szerint „a véleménynyilvánítás szabadságának gyakorlása nem irányulhat mások emberi méltóságának megsértésére". Az AB fent összefoglalt értelmezése alapján ez az alkotmánybeli szabály sem tekinthető a véleményszabadság abszolút korlátjának.

A határozat érdeme, hogy megkísérel a jogalkalmazásban mindeddig csak igen töredékesen alkalmazott, önálló értelmezést adni az emberi méltóság személyiségi jogának. Az AB döntéséből e tekintetben az következik, hogy:

- a közügyekre, közéleti szereplőkre vonatkozó vélemények, értékítéletek különleges védelmet élveznek,

- amely azonban nem terjed ki a közéleti személyiségek magán- vagy családi életére vonatkozó értékítéletekre (ha azok nincsenek összefüggésben a közügyekkel),

- valamint szintén nem terjed ki azon véleményekre, amelyek az érintett emberi státuszának teljes, nyilvánvaló és súlyosan becsmérlő tagadását valósítják meg (emberi mivoltát vonják kétségbe, a közügyek vitatásától elrugaszkodva, emberi minőségében becsmérlik, gyalázzák).

Ez utóbbi esetben már nem is a Ptk. 2:45. \$-ben foglalt becsülethez való jog sérül (annak megsértése lehetőségét a 2:44. \$által a közügyekben megfogalmazott vélemények számára biztosított védelem a kiemelt közszereplők - politikusok, a közhatalom gyakorlói - vonatkozásában akár teljes egészében ki is zárhatná), hanem az emberi méltóság joga. ${ }^{34}$ Vagyis az emberi méltóságnak - ellentétben a polgári bíróságok korábbi felfogásával - az alkotmánybírósági döntés értelmében a becsülethez és a jóhírnévhez való jogon túli, sajátos és önállóan alkalmazható tartalma van. Ez pedig egyben a vélemények teljes körủ védelmét és korlátozhatatlanságát illetően az 1994-es határozatban foglaltak kiegészítését és részbeni elvetését is jelenti.

33 7/2014. (III. 7.) AB határozat [62] bek.

34 Ptk. 2:42. $\$(2)$ bek. 
A tényállítások tekintetében a határozat úgy foglalt állást, hogy „a bizonyíthatóan hamis tények önmagukban nem állnak alkotmányos védelem alatt", ${ }^{35}$ kissé homályosan arra célozva ezzel, hogy bizonyos esetekben a valótlan tényállítások is részesülhetnek a véleményszabadság védelmében. A határozat később megállapítja, hogy „még az alkotmányos értékkel egyébként nem bíró, utóbb hamisnak bizonyult tények esetében is indokolt, hogy a jogi felelősségre vonás során a felróhatóság és az esetleges joghátrányok mértékének meghatározása körében figyelembe vegyék a közéleti viták minél szabadabb folyásának érdekét”. ${ }^{36}$ A „méltányolható közérdekből” szövegrész azonban a vélemény- és a sajtószabadság szükségtelen korlátozásának minősül, hiszen „[a] közügyek vitatása körében a közéleti szereplők személyiségi jogai védelmének a véleményszabadság gyakorlását biztosító korlátozása is minden esetben alkotmányos érdek és követelmény”, ${ }^{37}$ a véleményszabadság „korlátozhatóságát kizárólag más alapvető jog érvényesülése vagy valamely alkotmányos érték védelme érdekében teszi lehetővé. Az új Ptk. szerinti, közelebbről nem meghatározott és nem nevesített »méltányolható közérdek« nem tartozik ebbe a körbe."38

\subsection{Közügyek és közszereplök}

Az elmúlt évtized $\mathrm{AB}$-gyakorlata és a nyomában formálódó bírósági esetjog jobbára erősíti azon értelmezést, amely szerint a véleménynyilvánítással érintett ügy „közügy”-jellege az elsődleges szempont a személyiségvédelem csökkentett terjedelmének megállapításakor, nem pedig a közlés által érintett személy közszereplői státusa (vagy annak hiánya). A gyakorlat ugyanakkor nem egészen mentes az ellentmondástól, és ez elbizonytalaníthatja a világos választ kereső szemlélőt. ${ }^{39}$

A 7/2014. (III. 7.) AB határozat rögzíti a közügyek azonosításának elsődlegességét, mindazonáltal jelzi, hogy a közszereplői státus is fontos - bár a közügyjelleghez képest másodlagos - szempont lehet a személyiségvédelem mértékének megállapításánál. A közügyek hatással vannak az általuk érintett szereplök személyiségi jogainak érvényesülésére, ha pedig e személyek közéleti szereplőnek is számítanak, akkor jogaik még tovább szükülhetnek, amelynek mértéke közszereplői státusuk jellegétől függ (a politikustól a celebig).

„A jogalkalmazás során mindenekelőtt arra kell tekintettel lenni, hogy mivel a politikai véleményszabadság fókuszában elsősorban maguk a közügyek, nem pedig a közszereplők állnak, a közügyekre vonatkozó szólások mindegyike fokozott védelem alá tartozik, és ezáltal korlátozza az általa érintettek személyiségi jogainak

35 7/2014. (III. 7.) AB határozat [49] bek.

36 7/2014. (III. 7.) AB határozat [50] bek.

37 7/2014. (III. 7.) AB határozat [65] bek.

38 7/2014. (III. 7.) AB határozat [66] bek.

39 Az AB kapcsolódó gyakorlatáról lásd még: Balogh Éva: A megkülönböztetés művészete: bírói mérlegelés a közszereplőkkel kapcsolatos közlések szabadsága kapcsán. Fundamentum, (2016), 1. 22-38.; Balogh Éva: Alkotmánybíróság útvesztőben. Fundamentum, (2018), 2-3. 80-99. 
védelmét. A személyiségvédelem korlátozottsága tehát nem csupán a hivatásszerűen közszereplést vállalók esetében érvényesülő szabály, hiszen a közügyek vitatása adott esetben - a konkrét társadalmi vita erejéig - annál szélesebb személyi kört érinthet. Nem lehet figyelmen kívül hagyni azonban a megszólalással érintett személy státuszát sem: a közhatalmat gyakorló személyek és a közszereplő politikusok esetében a személyiségvédelem korlátozottsága mindenki máshoz képest szélesebb körben minősül »szükségesnek és arányosnak«". ${ }^{40}$

Ez a megközelítés nyer megerősítést a 14/2017. (VI. 30.) AB határozatban is: „[A] munkaügyi jogvita alapját jelentő tevékenység, vagyis az internetes portál tartalma és az ott közétett írások döntő részükben szakmai jellegủek és nem mutatnak olyan közéleti kötődést, amely ezt a tevékenységet egyértelmüen a közügyek szabad vitatásának körébe sorolja." ${ }^{41}$ A 8/2018. (VII. 5.) AB határozat alapján a magas egyházi tisztséget betöltő személyekre vonatkozó véleménynyilvánítás esetén is a közügyekkel való kapcsolódás határozza meg az érintettek személyiségi jogait illetően alkalmazandó mércét, e tekintetben nincs jelentősége annak, hogy ők nem gyakorolnak közhatalmat, és nem politikusok. ${ }^{42} \mathrm{Az}$ önkormányzati jegyzőre vonatkozó állítások föszabályként nem vonhatók ki a közügyek vitájának köréből, „a közügyek alakítóinak személyiségét, hitelességét érintő megnyilvánulások általában a közügyek vitájának védett körébe tartoznak".33 A politikai tanácsadó nyaralásáról közölt információk és képek is a közügy vitájához való hozzájárulásnak minősülhetnek, sőt az illető közszereplő státusáról vagy annak hiányáról zajló, nyilvánosság előtti diskurzus maga is egy közéleti vita, így arra nézve a csökkentett személyiségvédelem alkalmazása alkotmányosan indokolt. ${ }^{44} \mathrm{~A} 3030 / 2019$. (II. 13.) AB határozat alapügyének terheltje az ellene indított büntetőeljárásban a bíróság előtt megismételte, sőt újabb erősen kritikus értékítéletekkel gazdagította az indítványozóval kapcsolatos véleményét („szarkupac”, „gyalázat, civilizációs métely”, „nyilvános hullarabló”). Az alapügyben őt becsületsértés vétsége miatt elítélték, de a tárgyaláson elhangzottak terhelt általi - saját közösségimédia-felületein való - közzététele miatt indult újabb ügyben a bíróság felmentette. $\mathrm{Az} A \mathrm{AB}$ elutasította az ennek okán benyújtott alkotmányjogi panaszt azon az alapon, hogy a büntetőeljárásról szóló tájékoztatás közügy. ${ }^{45}$

Az AB gyakorlata azonban nem teljesen ellentmondásmentes, amint arra két határozat is rámutat. Az 1/2015. (I. 16.) AB határozat előzményeként szolgáló ügyben a sérelmezett vélemények magántermészetủ vitában hangzottak el, azaz a közügyek vitáiban alkalmazandó mércét az itt vizsgált ügyben nem kellett alkalmazni. Ezért is megkérdőjelezhető, hogy $\mathrm{az} A B$ nem elsősorban a vitatott véleménynyilvánítás

40 7/2014. (III. 7.) AB határozat [57] bek.

41 14/2017. (VI. 30.) AB határozat [40] bek.

42 8/2018. (VII. 5.) AB határozat [20]-[25] bek.

43 3263/2018. (VII. 20.) AB határozat [43] bek.

44 26/2019. (VII. 23.) AB határozat [29]-[34] bek.

45 3030/2019. (II. 13.) AB határozat [38]-[40] bek. 
kontextusát, hanem a sértett státusát vizsgálta. Az ügyvédként dolgozó sértettel összefüggésben pedig leszögezte, hogy „[a]z ügyvédként eljáró személy azonban önmagában ügyvédi minősége miatt nem tekinthető sem közhatalmat gyakorló személynek, sem közszereplő politikusnak". ${ }^{46}$ Ebből indirekte az következik, hogy az AB - a 7/2014. (III. 7.) AB határozatát követően, annak indokolásában foglaltaktól eltérve - visszatért a 36/1994. (VI. 24.) AB határozat szűkebb közszereplö-meghatározásához, holott nem elsősorban a személy státusát, hanem azon ügy „közügy”jellegét szükséges vizsgálni, amellyel kapcsolatban a vitatott vélemény elhangzott. A 3145/2018. (V. 7.) AB határozat többségi indokolása pedig kissé összekuszálja a közügy és a közszereplő szempontjai közötti viszonyt:

„Abban az esetben, ha a nyilvános közlés a közügyek szabad vitatását érinti, az alkalmazandó alkotmányjogi mérce megállapításához szükséges annak további vizsgálata, hogy a közléssel érintett személy - az adott helyzetben - közszereplői minőségben érintett-e. Önmagában ugyanis az a tény, hogy egy nyilvános közlés közéleti jellegü, nem vonja automatikusan maga után azt, hogy az érintett személyek személyiségvédelme lecsökken. A közszereplői minőség megállapítása mindig egyedi mérlegelés tárgya. [...] A megszólalás tárgya (közéleti kérdés) ugyanakkor nem az egyedüli szempontja a nyilvános közléssel érintettek személyi minőségének megállapításához. Elengedhetetlen annak vizsgálata is, hogy az érintett önkéntes elhatározása folytán váljon a közélet alakítójává. A véleménynyilvánítás szabadságának érvényesülése ugyanis kizárólag azokban az esetekben igazolható, amelyekben a részvevők a saját döntésük alapján váltak a közügyek másoknál aktívabb alakítóivá, vállalva ezzel az érintett közösség nyilvánossága előtti értékeléseket és bírálatokat is. A közügyek vitatása körében ezért az őket érintő vagy minősítő, a személyüket támadó véleménynyilvánításokat nagyobb türelemmel kell türniük". 47

Az indokolás, túl azon, hogy tévesen ítéli meg a közügyjelleg és a közszereplői státusz szempontjainak egymáshoz való viszonyát, elfogadja a rendőrképmás-ügyekben a Kúria által alkalmazott azon megközelítést, amely szerint „[a] joggyakorlat és a jogirodalom meghatározása szerint szereplésnek, ezen belül közszereplésnek az egyén önkéntes elhatározásán, autonóm döntésén alapuló olyan politikai, társadalmi, müvészeti tevékenység, megnyilvánulás tekinthető, amelyet egy meghatározott cél, szűkebb vagy tágabb értelemben a helyi közösség vagy a társadalom életének befolyásolása érdekében fejt ki”."8 $\mathrm{Az} \mathrm{AB}$ a rendőrképmás-határozatokban a közszereplés szükségszerủen önkéntes jellegének cáfolatát végül elkerülte, és a rendőrök szủkített jogát képmásuk védelméhez nem azon az alapon tekintette igazoltnak, hogy ők a Ptk. 2:48. $\mathbb{S}(2)$ bekezdése szerinti nyilvános közéleti szereplést végeznek, hanem a nyilvá-

46 1/2015. (I. 16.) AB határozat [39] bek.

$473145 / 2018$. (V. 7.) AB határozat [44], [48] bek.

48 1/2012. számú BKMPJE határozat, III. pont. 
nosság érdekének alkotmányos szempontjára alapozta e döntéseket (bővebben lásd később). Ettől még az a megközelítés, amely szerint a közszereplés minden esetben önkéntes elhatározáson alapul, egyértelműen téves, túlzottan szűkítő, amint arra Schanda Balázs alkotmánybíró párhuzamos indokolása is világosan mutat rá, példáját az Emberi Jogok Európai Bíróságának (EJEB) gyakorlatából véve:

„Azt már a hazai gyakorlat is leszögezte, hogy a szólásszabadság fokozott védelme tágabb körben irányadó, mint a »hivatásos közszereplők« köre [ld. 7/2014. (III. 7.) $\mathrm{AB}$ határozat]. Arra pedig már a strasbourgi gyakorlat iránymutatása világít rá, hogy a sajátos mércék alkalmazásához adott esetben semmilyen, az érintetteket legalább ad hoc önkéntes közszereplővé minősítő körülmény azonosítására nincs szükség: az ominózus eset egyszeri norvég fókavadászainak például eszük ágában sem volt, hogy önkéntesen »közszereplést « vállaljanak vagy közvita érintettjévé váljanak - a fókavadászat kegyetlenségeiről legitim módon folyó társadalmi vitában személyiségvédelmük mégis korlátozottabbá vált [EJEB, Bladet Tromsø és Stensaas kontra Norvégia (21980/93), 1999. május 20.]. Más kérdés, hogy a személyiségvédelem az érintettektől függően különböző mértékben lehet korlátozott, de ez már a közügyek vitáján belüli mércék kérdése, nem pedig a szólásszabadság fokozottan védett területének lehatárolásáról szóló mérlegelés." ${ }^{49}$

\subsection{A hírnév és a becsület védelme - tények és vélemények}

A 36/1994. (VI. 24.) AB határozatból következően a jó hírnév és a becsület megsértésére alkalmas közlések megítélésekor külön kell választani a tényállításokat és a véleményeket. Ezek további szempontok szerint differenciálandók. A Ptk. ezt már törvényi szinten is rögzíti, így a $2: 45$. $\$$ szerint a jó hírnevet tényközléssel, a becsületet véleményközléssel lehet megsérteni. A 7/2014. (III. 7.) AB határozat pedig szintén rögzíti azt, hogy a valótlan tények és a szélsőséges vélemények szabadsága, illetve korlátozhatósága eltérő alkotmányos mércék szerint ítélendő meg.

$\mathrm{Az} A B$ döntései szerint a tényállítások esetében különbséget kell tenni a valós (a bíróság előtt bizonyított) és a valótlan (nem bizonyított) tényállítások között. A valótlan tényállításoknál pedig további különbséghez vezethet a szándékosan vagy a közlő hivatása vagy foglalkozása szabályai szerint tőle elvárható körültekintés elmulasztásával, illetve a szakmai szabályok betartása mellett közzétett állítások eltérő megítélése. Bár az AB határozatai ilyen megkülönböztetést nem írtak elö, a joggyakorlat a véleményközlések esetében különbséget tesz a ténybeli alappal rendelkező vélemények és az ilyen alappal jellegüknél fogva nem rendelkező - indulatból fakadó, érzelmeket tükröző vagy csak egyéni, szubjektív értékítéletet magában foglaló - vélemények között. Ha az előbbi tekintetében a ténybeli alap valóságát a bíróság előtt sikerül bizonyítani, akkor a vélemény közlője mentesül a jogi felelősségre vonás alól,

49 3145/2018. (V. 7.) AB határozat [105] bek. 
legyen véleménye mégoly szélsőséges vagy bántó is. A ténybeli megalapozással nem rendelkező vélemények ellenben korlátozhatók maradnak, ha azok - a bírói gyakorlatban kialakult, bevett fordulatokat használva - indokolatlanul bántók, sértők, lealázók (gyalázkodások).

A 13/2014. (IV. 18.) AB határozatában az AB - általános érvénnyel, a büntetőjogon túlnyúlva - megállapította azon szempontokat, amelyek alapján a rágalmazási ügyek egyik legfőbb kérdésében, azaz a tényállítások és vélemények differenciálása során a bíróságoknak figyelembe kell venniük:

„[az] a kérdés igényel választ az eljáró bíróságoktól, hogy a publicisztika tényállításnak, avagy értékítéletnek minősül-e. Ennek során figyelemmel kell lenni arra, hogy az inkriminált mondat a teljes szöveg kontextusában nyer értelmet, amelynek célja az önkormányzat vagyongazdálkodásának kritikája volt, vagyis az írás az irónia és a túlzás eszközével élve bírálta a városi vagyongazdálkodást. Szükséges továbbá értékelni a publicisztika vélemény kontextusát, amely a helyi közösségen belül tapasztalható vagyoni egyenlőtlenségekre és a pazarló költségvetési gazdálkodásra hívta fel a közélet figyelmét. Mindezek alapján lehet dönteni abban a kérdésben, hogy a publicisztika tartalmaz-e egyáltalán olyan konkrétumot, amelynek igazságtartalma igazolható, ellenőrizhető lenne, vagy az írás egy olyan bírálatot kifejező értékítélet, amelynek éppen a lehetősége és ténye védett, annak tartalmára tekintet nélkül."50

A fenti szempontrendszer magánjogi jogvitákban is alkalmazható. A tényállítások és vélemények elhatárolása a konkrét ügyekben ezzel együtt is nehéz feladat. Egy ilyen bonyolult elhatárolási kérdéssel találkozott az $\mathrm{AB}$ két történész közötti vita ügyében. ${ }^{51}$ Az alapügy alperese azt nyilatkozta az indítványozóról, hogy amit az mondott, „egy szélsőjobboldali politikai provokáció, ami [...] törvényes eszközökkel is büntethető lenne, hiszen relativizálja a holokausztot, súrolja a holokauszt tagadását". Az indítványozó szeme előtt „két alapvető cél lebeg [...]: az új [...] intézet új ideológiai megfontolásaival függ össze, az új tekintélyuralmi rendszer tisztára kell, hogy mossa elődjét, a Horthy-rendszert. Teljesen nyilvánvaló, hogy ez a dolog erről szól, és igyekszik kimosni magát Horthyt is a népirtás bünéből, de nem lehet." Az alperes az indítványozóra utalva megjegyezte, hogy „csak azokat az embereket lehet megbízni ilyen kormányintézetek vezetésével, akik szakmailag, erkölcsileg, politikailag a szélsőjobboldal irányába nyitottak, a Horthy-rendszer restaurációjában gondolkodnak szellemileg". A fentiek átmenetet képeznek a tényállítás és a véleményközlés között, az $\mathrm{AB}$ is megosztott volt abban a kérdésben, hogyan minősítse az elhangzottakat. A többség azonban véleményeknek tekintette azokat. A kritikai elem, a bírálati jelleg tette - a többség megítélése szerint - véleménnyé az elhangzottakat, amelyekre így kevésbé szigorú mércét kellett alkalmazni, az alkotmányjogi panaszt pedig a testület elutasította.

50 13/2014. (IV. 18.) AB határozat [49] bek.

51 3001/2018. (I. 10.) AB határozat. 
A 3145/2018. (V. 7.) AB határozat két bulvárszereplő jogvitája összefüggésében rögzítette, hogy valakit egy vita során „pszichopatának” nevezni nem tényállítás, ha a közlő a kifejezést nem orvosi értelemben használja, hanem a köznyelvben bevetté vált minősítésként. ${ }^{52}$ A 3374/2019. (XII. 19.) AB határozat szerint pedig az a parlamenti vita során elhangzó közlés, amely szerint a Magyar Nemzeti Bank (MNB) elnöke „családjával együtt közpénzt lopott az MNB alapítványainak létrehozásával”, 53 nem tényállítás, hanem vélemény, ${ }^{54}$ ráadásul olyan, amelyet az érintett türni köteles. (Megjegyzendő, hogy az öttagú tanácsból két alkotmánybíró vitatta ezt az értelmezést, és az idézett szövegrészben foglaltak tényállításnak minősítését támogatták volna.)

\subsection{A hírnév és a becsület védelme - a türésküszöb a közügyek vitáiban}

Az AB feladata a „türésküszöb” meghatározásában nehéz és hálátlan. A testületnek meg kell kísérelni megtalálni a középutat, amely a demokratikus nyilvánosság szabadságára és - a legszélsőségesebb vélemények, valamint a valótlan állítások jó része esetére - fenntartja az emberi méltóság védelmének lehetőségét is. ${ }^{55} \mathrm{Az}$ AB kétségtelenül szűk mezsgyét keres döntéseiben, amellyel sem a korlátlan véleményszabadság hívei, sem a közbeszéd minőségéért aggódók vagy a személyiségi jogaikat védtelenül hagyottként érzékelő közszereplők nem maradéktalanul elégedettek. Talán éppen ez jelzi azt, hogy a testület jó úton jár. A kérdést, hogy pontosan milyen mértékben húzódik vissza a személyiségvédelem szabályainak érvényesülése a közügyek vitái során, és milyen magasnak kell lennie a közéleti szereplők és a közügyekben érintettek „türésküszöbének”, első ízben a 36/1994. (VI. 24.) AB határozat kísérelte meg meghatározni, ${ }^{56}$ amely mércét 20 év elteltével a 7/2014. (III. 7.) AB határozat - a fentiekben rögzítettek szerint - pontosította és módosította. A polgári bíróságok ítéleteivel szembeni alkotmányjogi panaszok nyomán született $A B$ határozatok pontosan követik ezen utóbbi határozat mércéjét. Ennek megfelelően pszichopatának nevezni

52 3145/2018. (V. 7.) AB határozat [81] bek.

53 3374/2019. (XII. 19.) AB határozat [2] bek.

54 3374/2019. (XII. 19.) AB határozat [32] bek.

55 Lásd: Juhász Imre: Fiat libertas, pereat mundus? Alkotmánybírósági Szemle, (2016), 1. 88-107.; Navratyil Zoltán: Az emberi méltóság magánjogi szerepe és a véleménynyilvánítás szabadsága. In Koltay András - Török Bernát (szerk.): Sajtószabadság és médiajog a 21. század elején 3. Budapest, Wolters Kluwer, 2016. 121-152.; Téglási András: Véleményszabadság vs. emberi méltóság- Egy rejtélyes alaptörvény-módosítás nyomában. Acta Humana, 3. (2015), 6. 25-47.; Molnár Hella: A közéleti szereplők személyiségi jogainak védelme. In Görög Márta - Menyhárd Attila - Koltay András (szerk.): A személyiség és védelme. Az Alaptörvény VI. cikkelyének érvényesülése a magyar jogrendszeren belül. Budapest, ELTE ÁJK, 2017. 15-32.

56 Nem túlzott sikerrel, mivel a bírói gyakorlat csak ritka esetben alkalmazta ténylegesen az AB 1994-es mércéjét. Szomora Zsolt: Az alkotmányos követelmények hivatkozási tipológiája becsületsértési és rágalmazási ügyekben hozott büntetőítéletekben. Jogtudományi Közlöny, 69. (2014), 10. 469-476. 
egy médiaszemélyiséget, ${ }^{57}$ vagy parlamenti vitában lopással vádolni az MNB elnökét ${ }^{58}$ nem haladja meg a közügyek vitájában irányadó türésküszöböt. ${ }^{59}$

Ami a büntetőjogi relevanciájú döntéseket illeti, a helyzet hasonlóan alakul. A 7/2014. (III. 7.) AB határozat büntetőjogi párja, a 13/2014. (IV. 18.) AB határozat, részben megerősítette a büntetőjog számára megfogalmazott 1994-es ismérvet, amely a valótlan tényállításokat érinti: „A közügyeket érintő véleménynyilvánítás szabadsága a valónak bizonyult tények tekintetében korlátlanul, míg a hamis tény állításával vagy híresztelésével szemben már csak akkor véd, ha a híresztelő nem tudott a hamisságról, és a foglalkozása által megkívánt körültekintést sem mulasztotta el. Az ilyen becsületsértésre alkalmas tényállítások a rágalmazás büncselekményének törvényi tényállási elemei közé illeszkednek, így büntetendők." ${ }^{60}$ A vélemények, értékítéletek szabadságával kapcsolatban azonban a 7/2014. (III. 7.) AB határozatot idézte: „A véleményszabadság már nem nyújt védelmet az olyan öncélú, a közügyek vitatásának körén kívül eső, így a magán- vagy családi élettel kapcsolatos közlésekkel szemben, amelyek célja a puszta megalázás, illetve a bántó vagy sértő kifejezések használata, vagy más jogsérelem okozása. [...] Ezenkívül nem védelmezi a közéleti vitában kifejtett véleményt sem, ha az abban megfogalmazottak az emberi méltóság korlátozhatatlan magját sértik, így az emberi státusz nyilvánvaló és súlyos becsmérlésében öltenek testet." ${ }_{1}$

A büntetőbíróságok ítéleteivel szembeni alkotmányjogi panaszok nyomán született AB határozatok jobbára pontosan követik a 13/2014. (IV. 18.) AB és a 7/2014. (III. 7.) $\mathrm{AB}$ határozatok mércéjét. ${ }^{62} \mathrm{~A}$ városi főjegyzőről azt írni, hogy „egy hazudozó, aljas, hitvány ember”, aki „törvénytipró”, a véleményszabadság által védett megnyilvánulás. ${ }^{63}$ Egy másik város jegyzőjét érintően úgy nyilatkozni, hogy „rasszizmus, diszkrimináció van, és nekünk, lakosoknak, ehhez még jó pofát is kell vágni. Kérem, hogy sújtsanak le már erre a rasszista képviselő testületre és jegyzőnőre”, illetve „számomra olyan, mintha adócsalók lennének, és ennek részese a helyi jegyző is”, és „a roma származású embereket megkülönböztet[i], hátrányos helyzetbe hozza”, továbbá „aki sorozatos jogtalanságok részese, az ne legyen a törvény betartója!", szintén a véleményszabadság által védett körbe tartozik. ${ }^{64}$

57 3145/2018. (V. 7.) AB határozat.

58 3374/2019. (XII. 19.) AB határozat.

59 Hasonlóképp lásd még a 3308/2020. (VI. 24.) AB határozatot.

60 13/2014. (IV. 18.) AB határozat [41] bek.

61 13/2014. (IV. 18.) AB határozat [40] bek.

62 A 13/2014. (IV. 18.) AB határozat elemzését lásd: Szomora Zsolt: Az Alkotmánybíróság büntetőítéletet megsemmisítő döntése a közszereplők büntetőjogi becsületvédelméről. Jogesetek Magyarázata, 5. (2014), 3. 13-22.; Szomora (2016) i. m.

63 3329/2017. (XII. 8.) AB határozat.

64 Miután a Kúria az AB határozata ellenére - újbóli mérlegelést követően - fenntartotta hatályukban a korábbi jogerős bírósági döntéseket, az AB újra, nyomatékosan jelezte, hogy mivel a közölt vélemény nem sértette az emberi méltóságot, azt a bíróságok alkotmányosan nem minősíthetik személyiségi jogot sértőnek. Lásd: 29/2019. (XI. 4.) AB határozat, [39]-[45] bek. Az ügy elemzéséről lásd: Botos Mihály Bálint - Gál Andor: Az Alkotmánybíróság határozata a véleményszabadság 
A 3159/2018. (V. 16.) AB határozat alapjául szolgáló tényállás szerint a tanár foglalkozású indítványozókról azt nyilatkozta egy város polgármestere, hogy ők „szakmailag a leggyengébbek", akiket emiatt bocsátottak el. A Kúria a felülvizsgálati eljárásban felmentette a polgármestert a becsületsértés vétsége miatt emelt vád alól. Az AB e döntéssel szembeni panaszt elutasította, de eközben nem hivatkozott a 2014-es döntéseire.

A 8/2018. (VII. 5.) AB határozat alapján viszont egy újságcikk címe önmagában is rágalmazó lehet, ezért ha valótlan állítást tartalmaz (a konkrét ügyben a cím: „Kényszerítés miatt nyomoznak [...] püspök ellen” volt), akkor annak véleményszabadság által védett vagy védtelenül hagyott jellegét külön is, a cikk szövegétől elválasztva is értékelni kell:

„[A] cikk címe műfajából és az említett szerepéből adódóan természetes módon tartalmazhat leegyszerüsítést, pontatlanságot: mind a figyelemfelkeltés indokolt mértéke, mind a tartalom lényegi megragadásának szüksége behatárolja a címadás pontosságát. Az így előálló leegyszerűsítések, pontatlanságok jogszerűségének kérdése azonban nem azon múlik, hogy a cikk többi, kifejtő része ellensúlyozzae azokat, hanem azon, hogy önmagukban véve olyan pontatlanságnak tekintendők-e, amelyek nem félrevezetők vagy megtévesztők valamely lényeges információ tekintetében. A cikk egésze szempontjából fontos körülménnyel kapcsolatban ugyanis a sajtócikk címében - sajátos szerepe miatt - önmagában sem szerepelhet lényeges, megtévesztő pontatlanság, valótlanság." ${ }^{5}$

Az AB a 3263/2018. (VII. 20.) AB határozatában a becsülethez való jog értelmezését a közügyek szabad vitatása fényében végezte el, kiemelve, hogy a becsülethez való jog a közügyek vitájában nemigen nyújt védelmet, és csak azon kijelentések szankcionálhatók, amelyek túllépnek a becsület sérelmén, és már az emberi méltóság korlátozhatatlan aspektusát sértik. ${ }^{66}$

A 3333/2018. (X. 26.) AB határozat példát mutat az AB 2014-ben rögzített mércéinek alkalmazása mellett jogsértőnek minősülő, a véleményszabadság határait túllépő megszólalásra. Az ügyben a Központi Nyomozó Főügyészség föügyész-helyetteséről tették közzé egy videomegosztó portálon a véleményt, miszerint „lehetséges, hogy a cionista törpe a diplomáját a tel-avivi nagybani piacon cserélte egy köszvényes kóser libáért". ${ }^{67}$ Bár e kijelentés közügy vitájában elhangzó véleménynek minősült, a főügyész-helyettes pedig státusára tekintettel is magasabb türésküszöbbel rendelkezik,

büntetőjogi korlátját tévesen megállapító bírósági döntések megsemmisítéséről: A valóságbizonyítás formalizált eljárásban történő lefolytatása mint a szólásszabadsághoz való jog érvényesülésének követelménye. Jogesetek Magyarázata, 11. (2020), 1-2. 7-14.; 3263/2018. (VII. 20.) AB határozat.

65 8/2018. (VII. 5.) AB határozat [32] bek.

66 3263/2018. (VII. 20.) AB határozat [40]-[41] bek.

67 3333/2018. (X. 26.) AB határozat [3] bek. 
a vele szemben megfogalmazott értékítélet túllépett a véleményszabadság védett határain. ${ }^{68}$

A 3030/2019. (II. 13.) AB határozat pedig azt rögzítette, hogy az előzményi ügyben egyébként becsületsértőnek minősülő kifejezések („szarkupac” és egyebek, lásd fent) újból közölhetők, ha az a kifejezések miatt induló, és a vita jellegére tekintettel közügynek minősülő bírósági eljárásról való tudósítás keretei között ismétlődnek meg. A közzététel ebben az esetben nem öncélú, nem a sértett emberi méltósága ellen, hanem az eseményről szóló tájékoztatásra irányul. ${ }^{69}$

A 3322/2019. (XI. 26.) AB határozat azt követően született, hogy az egyik megyei önkormányzat képviselője feljelentést tett amiatt, mert az indítványozó a képviselő közösségi oldalán őt egy kommentben „buzinak” nevezte. Az AB tanácsa szerint a megjegyzés minősítése a bíróságok által az alkotmányos szempontokat figyelembe véve született meg. $E$ körben $a z A B$ fontosnak tartotta azon körülményeket, hogy az közügyre vonatkozott, közéleti szereplőt érintett, és a bíróságok a lehető legenyhébb szankciót alkalmazták. ${ }^{70}$

A 3357/2019. (XII. 16.) AB határozat a kesznyéteni gyámhivatallal kapcsolatban megfogalmazott, a gyámhivatal munkatársai általi súlyos visszaélésekre és jogsértésekre utaló újságcikk nyomán állapította meg, hogy annak az ügyben érintett tartalmát megfelelően minősítette tényállításoknak, és azok bizonyításának elmaradása okán joggal állapította meg a rágalmazás megvalósulását. ${ }^{71}$

A 3048/2020. (III. 2.) AB határozat előzményeként az indítványozó a sértett közösségi oldalán az általa a helyi ravatalozó tervezési folyamatával kapcsolatban terjesztett álláspontot „vírusnak” nevezte. Ezzel arra kívánt utalni, hogy a sértett befolyásolta mások, köztük önkormányzati képviselők magatartását, így a megszólalás nem öncélú, a személyt sértő gyalázkodás, „hanem a sértett - személyét kétség kívül sértő, de - magatartásának közösségi hatására vonatkozó utalás".72 Ebből eredően a bíróságok támadott döntései, amelyek megállapították a becsületsértés megvalósulását, sértette a véleménynyilvánítás szabadságát.

A 3465/2020. (XII. 22.) AB határozat megállapította, hogy „a jogi személyek is joggal tarthatnak igényt arra, hogy tevékenységüket vagy személyiségüket az állam védje az öncélú gyalázkodással szemben"73 Ez annak ellenére van így, hogy az emberi méltóság értelemszerűen csak az emberi mivolthoz kötődhet. Mindazonáltal a konkrét esetben egy városi ingatlankezelő és vagyongazdálkodó zrt.-vel szemben megfogalmazott vélemények („a magánvádló felelőtlenül gazdálkodik, a város lakáspolitikája felelőtlen, [...] a magánvádló hűtlen és hanyag kezeléssel vádolható, és felelős »életveszély fenntartásáért, cselekvőképtelen és kiskorú személyek veszélyeztetéséért is«"),

68 3333/2018. (X. 26.) AB határozat [36]-[38] bek.

69 3030/2019. (II. 13.) AB határozat [40] bek.

70 3322/2019. (XI. 26.) AB határozat [30] bek.

71 3357/2019. (XII. 16.) AB határozat [37]-[39] bek.

72 3048/2020. (III. 2.) AB határozat [30] bek.

73 3465/2020. (XII. 22.) AB határozat [36] bek. 
amelyeket a bíróságok rágalmazásként értékeltek, az indítványozó által eltürni köteles megszólalásnak minősültek, így a bírósági döntés nem fér össze a véleményszabadság védelmével..$^{74}$

Azonban az utolsóként tárgyalt büntetőjogi vonatkozású ügyben született 3328/2017. (XII. 8.) AB határozat egy fontos ponton eltért a valótlan tényállítások közlésével megvalósuló rágalmazásra vonatkozó 1994-es - és 2014-ben megerősített - mércétôl. Az indokolás megállapította, hogy mivel a rágalmazás bűncselekménye csak szándékosan követhető el, a 36/1994. (VI. 24.) AB határozatban felállított mérce egyik fontos eleme, amely szerint az is büntethetö, aki ,azért nem tudott [a becsületet csorbító tényállítás] valótlanságáról, mert a hivatása vagy foglalkozása alapján reá irányadó szabályok szerint - az adott állítás tárgyára, a közlés eszközére és címzettjeire tekintettel - elvárható figyelmet vagy körültekintést elmulasztotta", nem tartható fenn tovább: „Az Alkotmánybíróság különös jelentőséget tulajdonított annak, hogy a jogalkotó a hatályos Btk.-ban sem rendeli büntetni a rágalmazás bủncselekmény gondatlan alakzatát. Erre, valamint a [34/2004. (IX. 28.) AB határozat] Indokolásában kifejtettekre tekintettel megállapította: a rágalmazás gondatlansággal is megvalósítható alakzatához kapcsolódó alkotmányos elvárás a továbbiakban nem tartható fenn." 75

Az említett 34/2004. (IX. 28.) AB határozat valóban tartalmaz idevágó fejtegetést. De megítélésem szerint sem ott, sem a 3328/2017. (XII. 8.) AB határozatban nem megfelelő a kiindulópont: az 1994-es határozat nem kívánta bevezetni a rágalmazás gondatlan elkövetési alakzatát, mindössze az adott állítás valóságtartalmának feltárása érdekében tanúsított magatartás tekintetében írt elő követelményt a mentesüléshez. Amint a 2004-es határozat helyesen megállapítja: „[a régi] Btk. 179. \$-ában foglalt rágalmazás bűncselekménye kizárólag szándékosan követhető el, és a szándékosság megállapításához elegendő, ha az elkövető tudata átfogja: az állított tény alkalmas a becsület csorbítására." A szándékosság tehát csak a sértő állítások közzétételére vonatkozik, nem arra, hogy csak szándékos hazugság lehet rágalmazó. Az elkövetőnek azt kell tudnia, hogy amit állít, az alkalmas arra, hogy a megcélzott személy társadalmi megítélését hátrányosan befolyásolja. Ez lehetséges valós tényállításokkal is, amelyek bizonyítását a bíróság megengedheti. ${ }^{76} \mathrm{Ha}$ a bíróság nem engedi a bizonyítást, akkor az egyébként igaz állítás is rágalmazó lehet. Az pedig, aki nem a kellő alapossággal járt el a valóságtartalom feltárásakor, elég, ha annyit tud, hogy a közlése hátrányos következménnyel járhat az általa érintett személyre nézve, és így elkövetési magatartása szándékos lesz. A rágalmazás bűncselekményét eshetőleges szándékkal is el lehet követni. ${ }^{77}$ Ebből eredően a 3328/2017. (XII. 8.) AB határozat indokolása e ponton nem helytálló, és kérdéses az is, hogy egyáltalán alkalmazza-e majd az AB a jövőbeni,

74 3465/2020. (XII. 22.) AB határozat [35]-[40] bek.

75 3328/2017. (XII. 8.) AB határozat [63] bek.

76 Btk. 229. \$.

77 Szomora Zsolt: Az emberi méltóság és egyes alapvető jogok elleni bűncselekmények. In Karsai Krisztina (szerk.): Kommentár a Büntetö törvénykönyvhöz. Budapest, CompLex, 2013. 475. 
büntetőjogi relevanciájú ügyekben. Amennyiben igen, az akár a véleményszabadság érvényesülési körének szüküléséhez is vezethet, hiszen az 1994-es határozatban rögzített, fent idézett alkotmányos követelmény nem a felelősség megállapításának feltételeit, hanem éppen az az alóli mentesülési okokat határozta meg. Azaz ha a gondossági kötelezettségek betartása a jövőben nem adhat mentesülést a rágalmazás megállapítása alól, akkor a valótlan tény szándékos közzététele önmagában elegendő lesz ahhoz.

\subsection{A hírnév és a becsület védelme - híresztelés}

A híresztelés a Ptk., a Btk. és a kapcsolódó joggyakorlat szerint a mástól származó információ továbbadását jelenti, és főszabályként azonos megítélés alá esik a közlőtől származó - azaz nem mások közléseként továbbított - valótlan és sértő tényállításokkal. A híresztelés a jóhírnév-védelem, ${ }^{78}$ a sajtó-helyreigazítás, ${ }^{79}$ valamint a rágalmazás ${ }^{80}$ tényállásában is szerepel - az elóbbi két esetben, ha megvalósul, polgári per alapja lehet. A sajtó-helyreigazítással foglalkozó - még jócskán az 1959-es Ptk. hatálya alatt született, de a Ptk., valamint a 2016. évi CXXX. törvény a polgári perrendtartásról (Pp.) alkalmazása körében is megfelelően irányadó - PK 14. sz. állásfoglalás szerint „[a]kkor is szükség van a valótlan tényállítás helyreigazítására, ha a közlés idegen forrásból származik. A jogszabály ezért nemcsak a közvetlen észleleten alapuló közlés, hanem a mástól szerzett értesülések továbbadása, közlése, vagyis a híresztelés esetében is lehetővé teszi a sajtó-helyreigazítást. Sajtó-helyreigazításának tehát az olyan valótlan tartalmú, a való tényeket hamis színben feltüntető sajtóközlemény miatt is helye van, amely egyébként híven közli más személy (szerv) tényállítását, nyilatkozatát, vagy átveszi más szerv (sajtószerv) közleményét" (I. pont).

Ez a tétel rögzíti tehát a föszabályt, és ennek érvénye kiterjeszthető a jóhírnévvédelem tényállásának értelmezésére is. A média régóta vitatja e szabály összeegyeztethetőségét a sajtószabadság jogával. A közügyekről, a nyilvános eseményekről adott beszámoló közzétételének érdeke ütközhet a hírnévvédelem, illetve a valós állítások közzétételének érdekével. A médiának számos esetben nincs vagy erősen korlátozott az ideje, lehetősége az információ valóságtartalmának ellenőrzésére. Önmagában a hamis állítások közéleti szereplők általi közzététele is hírértékű, a közügyekről való beszámoló e nélkül nem is képzelhető el. Továbbá a média szakkérdésekben nem dönthet a szemben álló álláspontok között, és nincs minden esetben lehetősége meghallgatni a másik felet, bár alapvető sajtóetikai elvárás, hogy törekedjen rá.

Az Alaptörvény hatálya alatt már három, a híresztelés kérdését érintő $\mathrm{AB}$ határozat született. Ezek közül az első, a 34/2017. (XII. 11.) AB határozat megállapította, hogy a sajtószabadság jogából fakadó „alkotmányos követelmény, hogy a közéleti szereplők sajtótájékoztatóján a közügyek vitájában egymást érintően tett kijelentésekről hủen,

78 Ptk. 2:45. \$(2) bek.

79 2010. évi CIV. törvény a sajtószabadságról és a médiatartalmak alapvető szabályairól (Smtv.) 12. \$.

80 Btk. 226. \$. 
saját értékelés nélkül tudósító, a közlések forrását egyértelműen megjelölő és a jóhírnevet esetleg sértő tényállításokkal érintett személy cáfolatának is helyet biztosító (vagy a válaszadás lehetőségét felkínáló) médiatartalom-szolgáltató tevékenységét nem lehet a személyiségi jogsértés polgári jogi szankcióit megalapozó híresztelésként értékelni”. ${ }^{81} \mathrm{Az}$ AB szerint a bíróságoknak vizsgálniuk kell, hogy a sajtó megfelelően járt-e el a tudósítás elkészítésekor, illetve annak tartalmát tekintve. ${ }^{82}$ A döntés kiemeli, hogy a sajtó elsődleges feladata a közéleti kérdésekről szóló információk nyilvánossághoz közvetítése, amelynek releváns eleme a közéleti szereplők megszólalásainak, álláspontjainak terjesztése, ugyanakkor e tevékenység ellátása során sem járhat el korlátozás nélkül.

Az újságírók egyik alapvető felelőssége a közölt hírek, információk hitelességének ellenőrzése, ez ugyanakkor nem jelenti azt, hogy a valótlan tényállításokért viselt felelősség kérdését minden esetben azonos szempontok alapján kellene megítélni, az alkotmányossági megfontolások mérlegelését figyelmen kívül hagyva. Az AB szerint ilyen körülménynek kell értékelni a közügyekre vonatkozó információk áramlásának érdekét, valamint a sajtó viszonyát az általa közölt kijelentésekhez, ekképpen például a közéleti szereplők sajtótájékoztatóiról szóló tudósítás esetén e szempontok különös súllyal veendők számításba. ${ }^{83}$ Ugyanakkor a sajtó tájékoztató tevékenységének szabadsága nem lehet korlátlan. Az újságírók egyik fő feladata az általuk közölni kívánt hírek valóságának ellenőrzése. ${ }^{84} \mathrm{~A}$ média felelősséggel tartozik a közéleti vitákban elhangzottak nyilvánossághoz való eljuttatásáért, egyúttal, mivel ilyen esetben inkább közvetítő eszközként (csatornaként), semmint önálló véleményformáló szereplőként lép fel, a jogsértő állítások továbbításáért fennálló felelőssége korlátozott. ${ }^{85}$

Az AB döntése rögzíti, hogy a bírói gyakorlat meghatározta azt az esetkört, amelyben a sajtó mentesülhet a mások közléseiben megfogalmazott jogsértő állításokért viselt felelősség alól. A polgári jogi híresztelés fogalma kapcsán kialakult gyakorlat kezdetben ilyennek tekintette a büntetőeljárással kapcsolatos hivatalos információk közlését, majd fokozatosan kiszélesedett a hasonló elbírálás alá eső ügyek köre más bírósági és hatósági eljárásokról szóló tudósításokra. Az AB döntése az esetkörökkel azonos megítélés alá tartozónak ítélte a közéleti szereplők sajtótájékoztatójáról szóló tudósítást is, hangsúlyozva, hogy ez nem érinti a sajtónak az általa közölt tények valóságtartalmának ellenőrzésére vonatkozó általános kötelezettségét, csupán az abból fakadó felelősség alóli mentesülés egyik esetkörét jelöli ki. ${ }^{86}$

A felelősség alóli mentesülés korlátozottsága tekintetében az $A B$ döntése meghatároz olyan feltételeket, amelyek teljesülése esetén a sajtó nem követ el jóhírnév-sértést a közéleti szereplők sajtótájékoztatóján elhangzottak továbbadása (híresztelése)

81 34/2017. (XII. 11.) AB határozat rendelkező rész, 1. pont.

82 34/2017. (XII. 11.) AB határozat [32] bek.

83 34/2017. (XII. 11.) AB határozat [41] bek.

84 34/2017. (XII. 11.) AB határozat [42] bek.

85 34/2017. (XII. 11.) AB határozat [46] bek.

86 34/2017. (XII. 11.) AB határozat [47] bek. 
esetén. E követelmények: a sajtótájékoztatón elhangzottak valósághủ közlése, a közlés forrásának azonosíthatósága (egyértelmű megjelölése) és a saját értékelés megfogalmazásától való tartózkodás. Ezen túlmenően az $\mathrm{AB}$ a vizsgált esetben a felelősség alóli mentesülés körében értékelhető feltételek közé tartozónak ítélte a megszólalással érintett ellenérdekủ fél álláspontjának a vitatott cikkhez kapcsolt közzétételét. A testület egyúttal leszögezte, hogy a valóság bizonyítása alóli mentesülés lehetőségével szembeni visszaélésként értékelendő a fenti feltételek bármelyikétől való tudatos eltérés, amely a felelösség megállapíthatóságának következményét vonhatja maga után, de az adott tényállás tekintetében más releváns körülmény is utalhat ilyen visszaélésre. ${ }^{87}$

A határozat kétségtelenül előremutató, és alkalmas arra, hogy a megmerevedett joggyakorlatot a véleményszabadság javára fellazítsák, de kritikával is illethető. A határozatban rögzített alkotmányos követelmény kiemeli a médiatartalom-szolgáltatókat, így a híresztelés esetén az objektív felelősségi alakzat alkalmazása alóli kivétel csak rájuk (a „sajtóra”) alkalmazható, azonban e megközelítés túlzottan szűkítő. A véleményszabadság a legtöbb esetben a beszélő személyétől függetlenül védi a közlés tartalmát (lásd például a személyiségvédelem vagy a gyülölködő kifejezések vonatkozó szabályait), és a Ptk. sem tesz különbséget a megszólalók között. Ezért ha valaki egy közéleti szereplő sajtótájékoztatójáról tudósít - felelősen eljárva -, akkor attól függetlenül kellene számára biztosítani a mentességet, hogy médiatartalomszolgáltató-e, vagy csak egyéni megszólaló (blogger, közösségimédia-felhasználó stb.). A véleményszabadság és a Ptk. dogmatikai rendje nem engedi e kettő szétválasztását a híresztelés vonatkozásában: a sajtónak nem kötelezettsége a közérdek szolgálata a közügyek vitáinak bemutatásával, viszont e szolgálatot más - „nem-sajtó” is elláthatja.

Szintén felvethető, hogy az alkotmányos követelmény abban a tekintetben is szükítő, hogy kizárólag a közéleti szereplők által tartott sajtótájékoztatókról szóló tudósításokra terjeszti ki a kivételi kört. A sajtótájékoztató ugyan fontos és gyakori módja az információszerzésnek, de korántsem az egyetlen. A közügyekben közzétett álláspontokról szóló beszámoló ugyanakkor a sajtó és a közönsége számára általában véve - a közlés módjától függetlenül is - fontos. A jogalkalmazói gyakorlat további formálódásakor indokolt lesz majd megvizsgálni annak lehetőségét, hogy a közéleti szereplők által közöltek pontos és részletes bemutatása, a másik fél megszólalási lehetőségének biztosítása, valamint a közlő megnevezése esetén a sajtó (illetve az előbbiek szerint bármely beszélő) általánosan mentesülhessen a híresztelés miatti felelősség alól.

A híresztelés tárgyában másodikként született döntés, a 3002/2018. (I. 10.) AB határozat, egy hónappal az elsőt követően rögtön szükítette az abban foglalt alkotmányos követelmény érvényesülési körét, újabb alkotmányos követelmény rögzítése nélkül. Az ügyben a média egy közéleti kérdéssel kapcsolatban tett közzé cikket (futballszurkolók rasszista megnyilvánulásai egy konyári iskola előtt), amely tartalmazott

87 34/2017. (XII. 11.) AB határozat [48] bek. 
egy linket is. A linkről elérhető volt egy olyan felvétel, amelyen a helyi roma önkormányzat elnöke - a per I. rendű alperese - a cselekményt a Jobbik politikai párttal hozza összefüggésbe („Bejött a Jobbik, bejött egy busszal”). A többségi vélemény azt állapította meg, hogy a média csak abban az esetben mentesül a híresztelt - a konkrét ügyben linkelt tartalomként közvetve elérhetővé tett - valótlan tényállításért viselt felelősség alól, ha az adott médiatartalom kizárólag a közügy vitájában részt vevő személyek megnyilvánulását tartalmazza, és azon felül semmi mást.

„Az Alkotmánybíróság értelmezése szerint - figyelemmel a 34/2017. (XII. 11.) $\mathrm{AB}$ határozatban megállapított alkotmányos követelményre - egy sajtótudósítás akkor esik kívül a híresztelés értelmezési körén, ha a médiatartalom fókuszában kizárólag a közéleti vitában részt vevő személyek megnyilvánulásainak naprakész és hiteles becsatornázása áll. Az adott esetben a sajtótudósítás fókuszában nem az I. rendủ alperes nyilatkozata állt, hanem az eseményekkel összefüggésben álló, egymásnak ellentmondó információk bemutatása. Ebből következően az adott esetben vizsgált sajtótudósítás híresztelésnek minősül."88

Az alkotmányjogi panasszal támadott ítélet alapjául szolgáló médiatartalom - amint arra a Kúria is felhívta a figyelmet ítéletében - tényfeltáró írás, oknyomozó cikk volt, ebből következően „az eseményekkel összefüggésben álló, egymásnak ellentmondó információk bemutatása" is megvalósult benne. Azonban álláspontom szerint a többségi indokolás úgy utal a 34/2017. (XII. 11.) AB határozatba foglalt alkotmányos követelményre, hogy valójában eltér attól. A 2017-es döntés azon tudósításokat vonja ki a híresztelés főszabálya alól, amelyek „a közéleti szereplők sajtótájékoztatóján a közügyek vitájában egymást érintően tett kijelentésekről hűen, saját értékelés nélkül tudósít[anak], a közlések forrását egyértelműen megjelöl[ik] és a jóhírnevet esetleg sértő tényállításokkal érintett személy cáfolatának is helyet biztosít[anak]". Ebből nem következik az, hogy - mint azt a 3002/2018. (I. 10.) AB határozat elvárná - a médiatartalom ne törekedhetne „az eseményekkel összefüggésben álló, egymásnak ellentmondó információk bemutatás[ára]".

Megkockáztatom, hogy a 34/2017. (XII. 11.) AB határozatban rögzített „saját értékelés" tilalma sem a tudósítást tartalmazó médiatartalom egészére, hanem a sajtótájékoztatón elhangzottak pontos közvetítésére vonatkozik. Azért gondolom ezt, mert nem életszerủ és a médiától nem is elvárható az olyan tudósítás, amely kizárólag a közéleti szereplő által mondottakat tartalmazza, mindenféle ehhez társuló, további szöveg nélkül. Ha mást nem is, címet, leadet, feliratokat kell füzni a tudósításhoz, amely már önmagában az elhangzottakhoz való alkotó hozzájárulást igényel a média részéről. Ha a média felvállalja $\mathrm{az} \mathrm{AB}$ által alkotmányos küldetéseként meghatározott tájékoztató szerepet, és így a feladatának azt tekintjük, hogy az igazságot mutassa be, járja körül, keresse azt meg, ne pedig egy, a saját tartalmával szemben

88 3002/2018. (I. 10.) AB határozat [77] bek. 
passzivitásra kötelezett kommunikációs felület legyen, akkor - a szemben álló nézetek bemutatása után - állást kell foglalnia az igazság és a hamisság kérdésében. De ekkor is felelősen kell eljárnia, és mások közléseit pontosan kell becsatornáznia, amely esetben mentesül a híresztelés miatti felelősség megállapítása alól. Megítélésem szerint a 34/2017. (XII. 11.) AB határozat alkotmányos követelménye ezt irányozza elő, nem általában véve, hanem a hivatalos sajtótájékoztatók vonatkozásában.

A 3002/2018. (I. 10.) AB határozat érvelése ezenkívül egy ponton egyértelmüen szembe megy a korábbi határozattal. Az „egymásnak ellentmondó információk” bemutatását a mentesülés elleni érvként említi, miközben a korábbi döntés a szemben álló érdekelt felek megszólítását vagy a megszólalásuk lehetőségének felajánlását a sajtó felelős megatartásának megállapításához szükséges feltételként rögzíti. Világos, hogy ha a médiatartalom kizárólag egy érdekelt nyilatkozatának közléséből áll, akkor a média csak részlegesen tölti be demokratikus szerepét. Ugyanakkor a 3002/2018. (I. 10.) AB határozat nem szúkíti a felelősség alóli mentesülés elvi lehetőségét a sajtótájékoztatón elhangzottak közlésére, így az elvben bármely, közügyet érintő megnyilvánulásra kiterjedhet, igaz, csak a fenti megszorításokkal (azaz ellentmondó információk és a média saját álláspontja nélkül).

A Magyar Jeti Zrt. v. Hungary ítélet ${ }^{89} \mathrm{az} A B$ e döntése által érintett ügy nyomán született meg. A kérelmező az EJEB előtt arra hivatkozott, hogy a magyar hatóságok megsértették a véleményszabadsághoz füződő jogát. Az ügy külön érdekessége, hogy a híresztelés egy internetes link cikkbe ágyazásával történt, így az internetes kommunikáció által lehetővé tett újfajta közlési mód jogi megítéléséről is szólt: lehet-e jogsértő egy olyan link puszta közzététele, amelyről egy jogsértő, valótlan állítást tartalmazó szöveg, videó érhető el? Az EJEB megállapítása szerint amennyiben az újságíró, illetve az általa készített médiatartalom nem fejezte ki egyetértését a jogsértő tartalommal, illetve jóhiszeműen, kellő gondossággal, a szakmai etika szabályainak betartásával járt el, a link közzététele önmagában nem valósít meg hírnévsértést. Figyelembe kell venni emellett a jogsértő tartalom kontextusát, hogy milyen ügyben jelent meg a nyilvánosságban, és kire vonatkozik. A kiemelt közéleti szereplők (jelen esetben egy parlamenti párt) türésküszöbe az ilyen esetekben is magasabban kell legyen az átlagosnál. ${ }^{90}$ Az ügyben született jogerős döntéssel tehát Magyarország megsértette a kérelmező véleményszabadsághoz füződő jogát.

Az AB egy következő, a híresztelés kérdésétérintő döntésében, a 3217/2020.(VI.19.) $\mathrm{AB}$ határozattal, elutasította a kúriai ítélet alaptörvény-ellenességének megállapítására és megsemmisítésére irányuló alkotmányjogi panaszt, mert úgy látta, hogy az megfelelően alkalmazta a 34/2017. (XII. 11.) AB határozatban foglalt alkotmányos követelményeket. A 3466/2020. (XII. 22.) AB határozat ugyanerre a következtetésre jutva szintén elutasította a panaszt. Az ügyben vitatott cikk úgy tudósított egy politikus sajtótájékoztatójáról, hogy nem adott lehetőséget az ott megnevezett másik fél, az indítványozó reakciójának közlésére. Az AB szerint ez azért maradt a jogszerűség

89 Magyar Jeti Zrt. v. Hungary, no. 11257/16., 2018. december 4-i ítélet.

90 Magyar Jeti Zrt. v. Hungary, no. 11257/16., 2018. december 4-i ítélet. 77-82. bek. 
keretein belül, mert a sajtótájékoztatón elhangzó, az indítványozóval kapcsolatban megfogalmazott állítások már korábban napvilágot láttak, azokra az indítványozónak volt lehetősége reagálnia. ${ }^{11}$

\subsection{A hírnév és a becsület védelme - internetes kommentek}

Az egyes online tartalmakhoz füzött kommentekkel (tartalomszolgáltatói moderálás mellett vagy anélkül, egy adott cikkhez, bejegyzéshez stb. az „olvasó” - felhasználó - által valamely internetes felületen közzétett hozzászólással) összefüggő kérdések nem voltak új keletűek az $\mathrm{AB}$ eddigi egyetlen komment-határozatának megszületésekor. A jogalkalmazási vita fő kérdése az, hogy a kommentelés lehetőségét biztosító platformok felelősségére vonatkozóan az elektronikus kereskedelmi szolgáltatások, valamint az információs társadalommal összefüggő szolgáltatások egyes kérdéseiről szóló 2001. évi CVIII. törvényt (Ekertv.) vagy a polgári jog általános szabályait kell alkalmazni, azaz a jogsértő - személyiségi jogot sértő - kommentről való tudomásszerzést követően a gyors eltávolítás mentesüléshez vezet-e, vagy a jogsértő tartalom közzétételében való részvétel esetén az objektív felelősség alapján a jogsértés ténye a felelősség megállapításához vezet.

Az Ekertv. értelmében ugyanis a tárhelyszolgáltató, noha főszabály szerint felelősséggel tartozik a jogsértő információkért, egyrészt nem köteles ellenőrizni az általa csak továbbított, tárolt vagy hozzáférhetővé tett információt, másrészt bizonyos feltételek teljesülése a felelősség alóli mentesülést eredményezi. A tárhelyszolgáltató akkor mentesül a felelősség alól, ha nem volt tudomása a tartalom jogsértő jellegéről, továbbá amint értesült róla, haladéktalanul intézkedett annak hozzáférhetetlenné tételéről. (A kommentelést biztosító tartalomszolgáltatást az Ekertv. fogalmi rendszere alapján lehetséges tárhelyszolgáltatásnak tekinteni.) Ezzel szemben mind az 1959-es Ptk., mind a hatályos Ptk. vonatkozó előírásai szerint a személyiségi jogot sértő tartalom közzétételének ténye az egyedüli döntő mozzanat, és az esetleges, jelzésre történő azonnali eltávolítás sem eredményez mentesülést az objektív jogkövetkezmények alól.

Az AB eddigi egyetlen, internetes kommentet érintő döntése, a 19/2014. (V. 30.) $\mathrm{AB}$ határozat, számos kritikát váltott ki. ${ }^{92} \mathrm{Az}$ adott ügyben a felek között a jogsértés ténye nem volt vitatott, azt a honlap üzemeltetője sem vonta kétségbe - így e tekintetben az $\mathrm{AB}$ sem folytatott le érdemi vizsgálatot -, mindössze azt kifogásolta,

91 3466/2020. (XII. 22.) AB határozat [51] bek.

92 Lásd pl.: Balogh Éva: Egy lépést hátra. A magyar Alkotmánybíróság döntése az internetes hozzászólásokért való felelősségről. Pro Futuro, 5. (2015), 1. 142-150.; Grad-Gyenge Anikó: Commentare necesse est - néhány gondolat az Alkotmánybíróság „komment-határozatáról”. Glossa Iuridica, 2. (2015), 1-2. 122-142.; Klein Tamás: A tárhelyszolgáltató „omnipotens” felelőssége mint alkotmányjogi problematika: A harmadik személy tartalmáért való szolgáltatói felelősség az interneten. In Koltay András - Török Bernát (szerk.): Sajtószabadság és médiajog a 21. század elején 3. Budapest, Wolters Kluwer, 2016. 349-374.; Koltay András: Az Alkotmánybíróság határozata az internetes kommentek polgári jogi megítéléséről. Jogesetek Magyarázata, 6. (2015), 1. 9-21. 
az Ekertv.-re alapozva érvelését, hogy őt bármilyen „nem saját” tartalomért felelősség terheli, függetlenül attól, hogy a bejegyzést értesítésre haladéktalanul eltávolította. ${ }^{93}$ A határozat szerint a honlap üzemeltetőjének felelőssége kizárólag a jogsértés tényén alapul, egyéb körülmény nem lehet döntő szempont, a jogsértés bekövetkezése esetén nem tehető különbség a különböző internetes oldalak, illetve az üzemeltető jogi felelőssége között. ${ }^{44}$

A határozat indokolása több tekintetben is ellentmondásos, és abból a - hagyományos médiától eltérő logika mentén müködő, de a közügyek vitái számára egyre fontosabb - online nyilvánosság alkotmányos sajátosságaira vonatkozóan általánosan is alkalmazható megközelítések nem olvashatók ki. ${ }^{95}$ De ezzel együtt is megjegyzendő, hogy a jogsértő kommentek miatti felelősség megítélésének kérdésében, ami a határozat által eldöntendő legfontosabb kérdés volt, az AB által alkalmazott megközelítés nem példa nélküli, összhangban volt a döntés idején irányadó magyar joggyakorlattal, és utóbb az EJEB sem tekintette azt - ti. a személyiségi jogok megsértése miatti általános polgári jogi felelősségi szabályok alkalmazását - az Emberi Jogok Európai Egyezményének 10. cikkével összeférhetetlennek. Így rendelkezett az EJEB az $\mathrm{AB}$ döntést megelőzően a Delfi v. Estonia ügyben ${ }^{96}$ és később, az $\mathrm{AB}$ határozat alapjául szolgáló ügy folyományaként elé kerülő MTE and Index v. Hungary ügyben is. ${ }^{97}$ Magyarország marasztalását ez utóbbi esetben nem önmagában a polgári jogi felelősség alkalmazása, hanem a kommentek tartalmának eltérő megítélése okozta, mivel az EJEB szerint azokat nem lehetett volna jogsértőnek minősíteni. A fő kérdés tekintetében tehát $\mathrm{az} \mathrm{AB}$ által alkalmazott megközelítés kompatibilisnek minősült az Egyezmény 10. cikkére vonatkozó strasbourgi gyakorlattal, így a fő kérdést illetően sem az AB döntését érintő heves kritikák, sem Magyarország EJEB általi marasztalását követő triumfálások nem tekinthetők megalapozottnak, még akkor sem, ha az AB-határozat indokolása valóban több tekintetben is zavaróan pontatlan vagy ellentmondásos. ${ }^{98}$

\subsection{A képmás védelme}

A Ptk. 2:48. \$-a szerint: „(1) Képmás vagy hangfelvétel elkészítéséhez és felhasználásához az érintett személy hozzájárulása szükséges. (2) Nincs szükség az érintett hoz-

93 19/2014. (V. 30.) AB határozat [56] bek.

94 19/2014. (V. 30.) AB határozat [64] bek.

95 Az indokolás bővebb és informálisabb kifejtését lásd a határozat előadó bírójától: Bragyova András: Szólásszabadság és sajtószabadság az internetes kommentek példáján. In Fejes Zsuzsanna - Török Bernát (szerk.): Suum cuique: Ünnepi tanulmányok Paczolay Péter 60. születésnapja tiszteletére. Szeged, Pólay Elemér Alapítvány, 2016. 473-490.

96 Delfi v. Estonia, no. 64569/09, 2015. június 16-i ítélet [Nagykamara].

97 MTE and Index v. Hungary, no. 22947/13, 2016. február 2-i ítélet.

98 Az MTE-döntést elemző higgadt értékelésekre nézve lásd: Sepsi Tibor: No comment? Az internetes hozzászólásokért való jogi felelősség. Fundamentum, (2015), 4. 106-110.; Szigeti Tamás - Simon Éva: A hozzászólás szabadsága: a közvetítő szolgáltatói felelősség aktuális kérdéseiről.

Fundamentum, 20. (2016), 2-4.113-124. 
zájárulására a felvétel elkészítéséhez és az elkészített felvétel felhasználásához tömegfelvétel és nyilvános közéleti szereplésről készült felvétel esetén." A szövegből úgy fest, hogy nem a közügyek, hanem a közszereplők, pontosabban a közszereplés azonosítása az egyedüli fontos szempont, és a nyilvános közéleti szereplésen kívül nincs mód a csökkentett személyiségvédelem alkalmazására - esetleg a 2:44. $\mathbb{\$}$ alkalmazása segíthet valamelyest. Ehhez képest az alkotmánybírósági gyakorlat a „rendőrképmás”ügyekben a 2:44. \$ figyelmen kívül hagyásával jutott el oda, hogy a véleményszabadság, illetve a tájékozódáshoz való jog szempontja a 2:48. \$alkotmányos értelmezésében is irányadó. ${ }^{99}$

A sajtó gyakran közöl álló- és mozgóképeket, amelyeken rendvédelmi dolgozók arccal, felismerhetően láthatók. E felvételek valamely közérdekủ ügyről szóló beszámolót kísérnek, tehát a rendőrök képmása nem önmagában hírértékủ. Az érintettek ezzel együtt is képmáshoz való joguk, magánszférájuk megsértéseként tekinthetnek e felvételek közlésére, kiemelve, hogy felismerhető ábrázolásuk nem hordoz többletinformációt, az általuk illusztrált, közügyet érintő beszámoló tartalmához érdemben nem „tesznek hozzá”.

Elsőként a 28/2014. (IX. 29.) AB határozat foglalkozott a rendőrökről készült felvételek összefüggésében konfliktusba kerülő képmásjog és a véleményszabadság egyensúlyának felállításával. A konkrét ügyben egy internetes hírportál „Rendvédelmi szakszervezet tüntetése” címmel jelentetett meg cikket, amelyhez egy „képgaléria” kapcsolódott. E képgyüjtemény két darabján egyedileg felismerhető módon, kétkét rendőr volt arccal felismerhetően látható a másokat is ábrázoló csoportképeken. A rendőrök szolgálati feladatukat látták el, a tüntetést biztosították, a képen passzívan álltak, magatartásuk önmagában nem volt különös vagy a sajtó számára bármely okból érdekesnek tekinthető. A tudósításhoz a képek többletinformációt nem adtak hozzá, de nem is ábrázolták sértő, bántó, lealacsonyító módon vagy eltorzítva az érintett rendőröket.

Fontos megjegyezni, hogy az $\mathrm{AB}$ nem a Ptk. által biztosított kivételek egyikébe próbálta beerőltetni a tényállást. Az inkriminált képek nem voltak tömegfelvételek, és az $\mathrm{AB}$ elkerülte azt, hogy a rendőrök közterületen való munkavégzését, szolgálatteljesítését nyilvános közszerepelésnek minősítse, hiszen nem is tekinthető annak. Korábban a Legfelsőbb Bíróság jogegységi határozata a közszereplői státus hiányával érvelt a rendőrképmások védelme mellett, de a rendőr föszabályként - bár közhatalmat gyakorol - nem közszereplö, a nyilvánosság elött végzett munkája pedig nem közszereplés. ${ }^{100}$

A rendőr vagy más rendvédelmi dolgozó tevékenységéről való beszámoló azonban fogalmilag közügyet érint, éppen a közhatalom gyakorlásának átláthatósága,

99 A képmáshoz való jog gyakorlatának átfogó bemutatását lásd: Boronkay Miklós: A képmáshoz és a hangfelvételhez füződő jog. In Csehi Zoltán - Koltay András - Navratyil Zoltán (szerk.): A személyiség és a média a polgári és a büntetöjogban. Budapest, Wolters Kluwer, 2014. 11-56.

100 A rendőrök közszereplői státusa elleni érvelést lásd: Pokrócos György: A rendőr képmásának nyilvánosságra hozatala. Belügyi Szemle, 67. (2019), 2. 89-108. 
bírálhatósága miatt, ezért nem elegendő azt igazolni, hogy ők nem közszereplők. ${ }^{101}$ Az AB általános érvénnyel - azaz nem csak a rendvédelmiekre, sőt nem csak a közhatalom gyakorlóira vonatkozóan - mondta ki, hogy a képmás szabadon közölhető, „[a] nyilvános helyen készült, nem sértő, az érintett személyt tárgyilagosan ábrázoló felvétel általában nyilvánosságra hozható engedély nélkül, ha az a közérdeklődésre számot tartó tudósításhoz kapcsolódik és a jelenkor eseményeiről való szabad tájékoztatásához kötődik". ${ }^{102}$ Így kell megítélni a rendőri intézkedésről készült képfelvételeket is. ${ }^{103}$ A Kúria utóbb elfogadta e megközelítést: „[a]mennyiben a közhatalmat gyakorló személy fellépésére a közéletet befolyásoló események során kerül sor, a képmáshoz való személyiségi jogainak gyakorlása, azok korlátozhatósága az általános, azaz a közéleti eseményeken pusztán jelenlévő magánszemélyek jogvédelmének szabályaihoz képest eltérő megítélés alá eshet."104

$\mathrm{Az} A \mathrm{~B}$ döntése nyomán tehát a Ptk. értelmezésébe be kell vonni az alkotmányos szempontokat is, amelyek a szabad tudósításhoz, az információkhoz való hozzájutáshoz, azaz a vélemény- és sajtószabadsághoz kapcsolódnak. Az AB és a Kúria az egyedi ügyekben e szempontot egy ideig még nem egységesen mérlegelte, amint azt a valódi alkotmányjogi panaszok után született újabb $\mathrm{AB}$-határozatok igazolják, amelyek újra megerősítették a nyilvánosság érdekeihez füződő szempont mérlegelésének jelentőségét. ${ }^{105}$

Mivel a Kúria az $\mathrm{AB}$ döntése nyomán meghozott újabb ítéletében is jogsértőnek minősítette a képek közlését, újból az AB elé került az ügy. A Kúria abból indult ki, hogy a passzívan ácsorgó rendőrök képmásának közlése nem hordozott többletinformációt, ezért az $\mathrm{AB}$ által előírt mérlegelés eredményeképpen a bíróság joggal jut arra a következtetésre, hogy a képek közlése nem szükséges a megfelelő tájékoztatáshoz, így azok közzététele jogsértő. De ez az AB döntésének félreértése, amint azt a 3/2017. (II. 25.) AB határozat egyértelművé teszi. A kiindulópont ugyanis nem az, hogy csak a tájékoztatási tevékenység szempontjából releváns többletinformáció közlése esetén szorul vissza a képmáshoz való jog, éppen ellenkezőleg: az csak akkor érvényesíthető, ha a közlés visszaélésszerü, öncélú, eltorzított. A vélelem tehát amellett szól, hogy a rendőrképmások közlése nyilvános eseményről való tudósításhoz kapcsolódóan megengedett.

„A bíróságok ilyen körülmények felmerülése esetén az Smtv. és az Mttv. hatálya alá tartozó sajtószerv esetén vizsgálhatják a tudósítás egészének tisztességességét

101 A kérdésben benne rejlő alkotmányos problematikára nézve lásd: Balogh Adrienn - Hegyi Szabolcs: A Kúria jogegységi határozata a közhatalmat gyakorlókról készült képmás és hangfelvétel nyilvánosságáról. Közszereplö-e a nyilvános helyen szolgálatot teljesítő rendőr? Jogesetek Magyarázata, 5. (2014), 2. 29-35.; Somody Bernadette: A rendőrarcképmás-ügy mint az alapjogi ítélkezés próbája. Fundamentum, 20. (2016), 1. 103-112.

102 28/2014. (IX. 29.) AB határozat [44] bek.

103 28/2014. (IX. 29.) AB határozat [43] bek.

104 1/2015. számú BKMPJE határozat, IV. 3. pont.

105 Lásd: 16/2016. (X. 20.) AB határozat és 17/2016. (X. 20.) AB határozat. 
és jóhiszeműségét, amely vizsgálat során azonban a feleknek - perbeli jóhiszeműségük tudatában - lehetőséget kell adni az ilyen állítások megtételére, a bizonyítékokkal való alátámasztására, cáfolatára. Ha ilyen körülmény nem merült fel azonban - mint ahogy a perbeli esetben soha nem volt kérdéses, a felperesek sem állították, hogy a tudósítás hamisan, ebből következően öncélúan ábrázolta volna jelenlétüket és szerepüket a tudósítással érintett eseménynél -, a bíróságok az Alaptörvény Alkotmánybíróság által a [28/2014. (IX. 29.) AB határozatban] meghatározott értelmezési tartományának megfelelően a jelenkori események bemutatásához füződő alkotmányos érdek primátusát kötelesek érvényesíteni." ${ }^{106}$

Más hivatásrendek képviselőiről is készülhet nyilvános eseményen, akaratukon kívül képfelvétel. A 3021/2018. (I. 26.) AB határozat a tárgyaláson eljáró jogi képviselők - a perben a rendőrség képviseletét ellátó jogtanácsosok - képmáshoz való jogát érintette. A jogtanácsosok a tárgyaláson nem járultak hozzá, hogy róluk képfelvétel készüljön, a bíróság ezt követően rendelkezett arról, hogy kép- és hangfelvétel kizárólag a per felperesi oldaláról és magáról a bíróságról készülhet. Az AB határozat egyik indítványozója mégis készített felvételeket, amelyen a jogtanácsosok egyedileg felismerhetően szerepeltek. A később közzétett felvételen bemutatták az ítélet nyomtatott változatát is, amelyen olvasható volt a jogi képviselők neve is, az alábbi kommentár kíséretében: „Megdöbbentő igazából az, amilyen alamuszi módon és hát elvtelen módon védik a pintéri rendőrséget jogtanácsosai."

$\mathrm{Az} \mathrm{AB}$ nem látta indokát a kúriai döntés megsemmisítésének, amely jogsértőnek minősítette a felvétel elkészítését és közzétételét. Fontos szempontnak minősült az, hogy a felvételek egy bírósági tárgyaláson készültek, amelynek nyilvánosságára speciális szabályok vonatkoznak, illetve hogy e szabályok alapján az eljáró bíró jogszerüen, végzésben tiltotta meg a felvételkészítést. ${ }^{107}$ Mind a kontextus, mind az érintettek szerepe elhatárolja ezen ügyet a rendőrképmás-ügyektől, „a képfelvételeknek a bírósági végzés tiltása ellenére történő rögzítése és nyilvánosságra hozatala - a bírói mérlegelés nyilvánvaló megalapozatlanságának hiányában - nem tekinthető a sajtószabadság megfelelő, visszaéléstól mentes gyakorlásának". ${ }^{108}$

A 23/2019. (VII. 18.) AB határozat indítványozója egy televíziós szolgáltató, amely a híradójában tudósított egy, a Kúria előtt folyó tárgyalásról, amelynek során a vádlottat kísérő büntetés-végrehajtási dolgozó arcát nem takarta ki, őt felismerhetően

106 A rendőrképmás-ügyekről és az általuk felvetett kérdésekről átfogóan lásd: Fejes Erik: A rendvédelmi testületek hivatásos állományába tartozó személyek képmáshoz füződő jogának korlátozhatósága. In Görög-Menyhárd-Koltay (2017) i. m. 143-161.; Papp János Tamás: Az Alkotmánybíróság két újabb határozata a rendvédelmi dolgozók képmásának nyilvánosságáról. Jogesetek Magyarázata, 7. (2016), 4. 5-11.; Papp János Tamás: A rendőrök képmáshoz való jogának kérdése. In GörögMenyhárd-Koltay (2017) i. m. 119-142.; Sándor István: A képmáshoz való jog és a sérelemdíj bírósági gyakorlatának tendenciái. Belügyi Szemle, 68. (2020), 4. 53-69.; Tóth J. Zoltán: Rendőrképmás: sajtószabadság és képmáshoz való jog a polgári jogi és az alapjogi jogosultságok keresztútján. Pro Futuro, 7. (2017), 2. 110-128.; 3/2017. (II. 25.) AB határozat [25] bek.

107 3021/2018. (I. 26.) AB határozat [24] bek.

108 3021/2018. (I. 26.) AB határozat [30] bek. 
bemutatta. Az ügyben $\mathrm{az} \mathrm{AB}$ a rendőrképmás-ügyek tényállásától egy fontos ponton eltérő kérdést kellett hogy megítéljen: a közhatalmat gyakorló, bírósági tárgyaláson - azaz nem közterületen - jelen lévő személy képmása közzétehető-e a tudósítás keretében? ${ }^{109}$ A testület megállapította, hogy az ügyben született bírósági döntések a képmáshoz való jog védelméből indultak ki, ugyanakkor nem rögzítették a tudósítás egyetlen olyan elemét sem, amely az érintett méltóságát sértette volna. Azonban „közhatalmat gyakorló személy e minőségében folytatott tevékenységének képi bemutatása csak akkor ütközik akadályba, ha ennek külön alkotmányos indoka van. Az igazságszolgáltatás rendje és a bíróság függetlensége igazolhatja a sajtószabadság korlátozását a tárgyalóteremben, de önmagában a felismerhetővé válás nem ilyen ok. A közhatalmat gyakorló személy - összhangban a [28/2014. (IX. 29.) AB határozatban] levont következtetésekkel - a bírósági tárgyaláson sem hivatkozhat az emberi méltóság védelmére amiatt, mert egy médiatartalomban felismerhetővé válik." 110

$\mathrm{Az}$ AB gyakorlata kiterjed a közéleti és a politikai szereplők képmásának közlésével összefüggő alkotmányos kérdésekre is. A 3313/2017. (XI. 30.) AB határozat alapján a bírósági tárgyaláson a politikai szereplő terheltről készült kép - még ha utóbb az eljárásban fel is mentették - közérdeklődésre tarthat számot, a terhelt közéleti szereplői minőségéhez kapcsolódik. A média objektív módon, képi eszközökkel is tudósíthat egy büntetőeljárás állásáról, ha a tudósítás összhangban áll az adott eljárás aktuális állásával, és tiszteletben tartja az ártatlanság vélelmének alkotmányos alapelvét. Önmagában a képi bemutatás nem sérti ezen elvet, és a terhelttel szemben alkalmazott fizikai kényszerítő eszközök (bilincs) bemutatása sem minősül eleve visszaélésszerűnek vagy méltóságot sértőnek. ${ }^{111}$ A személyiségi jogsértésre hivatkozó indítványt az $\mathrm{AB}$ ennek megfelelően elutasította.

A 3348/2018. (XI. 12.) AB határozat egy másik politikai közszereplő terhelt képmásának közlését követően indult. Az indítványozó internetes hírportál cikkének illusztrációjaként egy, az illetőről korábban, egy bírósági büntetőeljárás során, egy másik hírportál számára készült képet használt. Fontos körülmény, hogy az érintett közszereplő a kép közzétételét követően korábban az elkészítő hírportállal szemben polgári pert nyert, sikerrel hivatkozva a képmásával való visszaélésre. Az AB azonban a jelen ügyben rögzítette, hogy ezzel együtt is, a kép felhasználásának alkotmányossága a konkrét esetre nézve, külön vizsgálható. ${ }^{112} \mathrm{~A}$ kép szorosan összefügg az újabb cikk tartalmával és az ott bemutatott, közérdeklődésre számot tartó bírósági eljárással, amely a korábbi politikus közéleti szereplői minőségéhez, tisztségéhez kapcsolódott. Továbbá a fénykép nem ábrázolja őt megalázó helyzetben, súlyosan bántó vagy az emberi méltóság korlátozhatatlan, az emberi státuszt meghatározó lényegét sértő módon. ${ }^{113}$ Ennek megfelelően a képmás közzététele nem minősül a sajtószabad-

109 23/2019. (VII. 18.) AB határozat [29]-[30] bek.

110 23/2019. (VII. 18.) AB határozat [41] bek.

111 3313/2017. (XI. 30.) AB határozat [51]-[62] bek.

$1123348 / 2018$. (XI. 12.) AB határozat [36] bek.

113 3348/2018. (XI. 12.) AB határozat [37] bek. 
ság jogával való visszaélésnek, az ettől eltérően döntő ítélőtáblai ítélet Alaptörvényellenes. ${ }^{114}$

A 26/2019. (VII. 23.) AB határozat előzményeként a nyilvánosságot jobbára kerülő politikai tanácsadóról külföldi nyaralásán készültek felvételek, amelyeket az általa meglátogatott szórakozóhely megbízásából készítettek. Fontos körülmény, hogy az intézmény általános szerződési feltételei szerint a tanácsadó hozzájárult ahhoz, hogy reklámcélra a személyére is kiterjedő felvétel készüljön, és azt a szórakozóhely a saját tevékenysége során felhasználja. E felvételeket közölte újra egy magyar internetes hírportál. Az AB elutasította az alkotmányjogi panaszt, mert a tanácsadó nyaralásáról készült beszámoló közügynek minősült, és amennyiben „a sajtó közügyek vitatásával kapcsolatos ügyben, közszerepléssel összefüggésben tesz közzé képmást, a »képmásvédelem « csak akkor lehet a sajtószabadság valós korlátja, ha a képmás közzététele - a felismerhetővé váláson túlmutatóan - valamilyen alapjog sérelmét (különösen az emberi méltóság vagy a magánélethez való jog megsértését) okozza". ${ }^{115}$ A cikk és képi illusztrációja nem volt hírnév- vagy becsületsértő, és „a sajtó a közügyek vitatásával összefüggésbe hozhatóan osztott meg médiatartalmat a közéletre hatást gyakorló magánszemély magánéletéről. Mivel jelen esetben épp a magánélet (az érintett vagyoni helyzete, életvitele) volt a demokratikus vita tárgya, az indítványozó a felvétel elkészítéséhez és promóciós célú megosztásához hozzájárult, ezért helyesen értelmezte a bíróság, hogy ennek az információnak a széles közvéleménnyel való megosztása nem jelenti az indítványozó emberi méltóságának vagy magánélethez való jogának a megsértését." ${ }^{116}$

A 3467/2020. (XII. 22.) AB határozat egyik indítványozója egy politikus, a másik pedig annak nem közszereplő házastársa. A támadott bírósági döntés elutasította a képmáshoz való joguk védelmére vonatkozó igényüket. Az ügy tényállása szerint egy internetes hírportál közölte a politikus fényképeit, valamint a közösségimédiafiókjához illesztett profilképét, amelyen házastársával együtt látható. Az AB megállapította, hogy a politikusról készült képek egyike sem tekinthető magánéleti esemény ábrázolásának. ${ }^{117} \mathrm{~A}$ feleség ugyan alappal hivatkozhatna a magánéletéhez füződő jogai megsértésére képmása közzététele esetén, de a konkrét esetben a profilképről - annak kis mérete és felnagyíthatatlansága miatt - nem vált felismerhetővé, így alapjogának sérelme sem következett be. ${ }^{118}$

A 3019/2021. (I. 28.) AB határozat azt követően született, hogy az egyik internetes portál olyan cikket tett közzé, amely azt elemzi, hogy egy megyei jogú város polgármesteréhez milyen kapcsolat füz egy családot, és tagjainak vagyoni helyzete miképp alakult, emellett más médiaszolgáltatóktól származó fényképfelvételeket is közölt

114 3348/2018. (XI. 12.) AB határozat [38] bek.

115 26/2019. (VII. 23.) AB határozat [40] bek.

116 26/2019. (VII. 23.) AB határozat [42] bek.

117 3467/2020. (XII. 22.) AB határozat [69] bek.

118 3467/2020. (XII. 22.) AB határozat [72] bek. 
a polgármesterről és a családtagokról. ${ }^{119}$ A bíróságok megállapították a képmáshoz való jog megsértését. $\mathrm{Az} A B$ döntésének fontos szempontja volt, hogy a közölt felvételek nem a cikk illusztrálása céljából, hanem egy korábbi közszereplés alkalmával készültek. A cikk tartalma ugyanakkor közügyet érintett. ${ }^{120} \mathrm{Az} \mathrm{AB}$ mérlegelést követően alkotmányosnak fogadta el a bíróságok azon döntését, amely „a fényképfelvétel közlését a nem közhatalmat gyakorló érintett hozzájárulásához köti az olyan esetekben, amikor a felvétel nem kapcsolódik ahhoz a közszerepléshez, amiről a közlés szól”."121 $\mathrm{Az} \mathrm{AB}$ a megsemmisítésre irányuló indítványt elutasította.

\subsection{A magánélet és a személyes adatok védelme a Ptk.-ban}

A magánélet védelme a Ptk.-ban nevesített személyiségi joggá vált (2:43. $\$ b)$ pont), amelynek önálló tartalmát a bírói gyakorlat alakítja. E személyiségi jog terjedelme is a közügyek nyílt vitatásának érdekén keresztül határozandó meg, akárcsak a magánélethez való általános joggal szükségszerüen átfedésben lévő személyes adatok védelméhez való jog. ${ }^{122}$

A Quaestor vállalatcsoport körüli botránnyal kapcsolatban egyazon magánszemély hét $\mathrm{AB}$-döntésben is szerepelt indítványozóként. ${ }^{123} \mathrm{Az}$ előzményképpen perbe fogott lapkiadó, televíziós médiaszolgáltató és internetes hírportálok kiadói a Quaestor-botránnyal kapcsolatban közöltek cikkeket, amelyekben az indítványozó hozzájárulása nélkül nyilvánosságra hozták nevét, korábbi munkahelyeinek megnevezését, élettársi kapcsolatának tényét és élettársának nevét, valamint élettársa családi kapcsolatait, ezen keresztül az indítványozó tágabb értelemben vett családjával kapcsolatos adatokat. (Az indítványozó magánszemély, aki a Quaestornál dolgozott, élettársa pedig a legfőbb ügyész lánya. A cikkek ezen információkból következtettek arra, hogy az ügyben az ügyészség fellépésének állítólagos késlekedéséhez a munkatársi és családi kapcsolatoknak köze lehetett. Ezen sugalmazás valóságtartalmát a cikkek nem próbálták meg bizonyítani.) Az elózményi döntésekben a Kúria azon korábbi bírósági ítéleteket hagyta helyben, amelyek teljes egészében elutasították a magánélethez és a személyes adatok védelméhez füződő személyiségi jogok megsértésnek megállapítására irányuló igényt. A hét döntés közül e tekintetben egy kivétel akad, amelyben - mivel a bíróság első- és másodfokon is megállapította a magánélet és a személyes adatok védelméhez füződő jog sérelmét, amit a Kúria is hatályában

119 3019/2021. (I. 28.) AB határozat [2] bek.

120 3019/2021. (I. 28.) AB határozat [36] bek.

121 3019/2021. (I. 28.) AB határozat [38] bek.

122 A „magánélethez való jog” mint személyiségi jog értelmezéséről, lehetséges tartalmáról lásd: Menyhárd Attila: A magánélethez való jog a szólás- és médiaszabadság tükrében. In Csehi-KoltayNavratyil (2014) i. m. 177-226.; Görög Márta: A magánélethez való jog mint a személyiségi jog újabb, magánjogi kódexben nevesített vonatkozása. In Balogh (2016) i. m. 51-63.

123 3209/2020. (VI. 19.) AB határozat, 3210/2020. (VI. 19.) AB határozat, 3211/2020. (VI. 19.) AB határozat, 3212/2020. (VI. 19.) AB határozat, 3213/2020. (VI. 19.) AB határozat, 3214/2020. (VI. 19.) AB határozat, 3215/2020. (VI. 19.) AB határozat. 
fenntartott - az AB elutasította a panaszt. ${ }^{124}$ A bíróságok ezen utóbbi döntés előzményeképpen az indítványozó nevének közlését ítélték jogsértőnek, és megállapították, hogy az élettársi kapcsolat tényének és élettársa családi kapcsolatainak nyilvánosságra hozatalával nem sérült a felperes magánélet védelméhez füződő személyiségi joga, $\mathrm{az} \mathrm{AB}$ pedig ezzel egyetértett.

$\mathrm{Az} A B$ valamennyi döntésében megállapította, hogy a közügyben való érintettség, a közügy jelentőségére is tekintettel, szükségessé teheti a nem közszereplő indítványozó személyes adatainak védelméhez füződő jogának korlátozását ${ }^{125}$ - az egyszerüség kedvéért a továbbiakban csak az első határozatra hivatkozunk, de az érvelés lényegében mindegyikben azonos volt.

Ami a név közzétételét illeti, a megfelelő tájékoztatás név nélküli (anonim) tudósítással is elvégezhető lett volna, így a sajtó magatartása sérti az indítványozó magánszféráját. ${ }^{126} \mathrm{~A}$ korábbi munkahelyének a hozzájárulása nélküli közzététele nem minősült jogsértőnek. ${ }^{127}$ A Quaestor vezetőjével fennálló munkakapcsolat, valamint az indítványozót a legfőbb ügyészhez füző magánéleti kötődés olyan, „a közérdeklỏdésre számot tartó ügyhöz kapcsolódó személyes adat, amelyek nyilvánosságra hozatala az érintett közügy megvitatása érdekében nem tekinthető sem önkényes, sem indokolatlan közlésnek, az a véleménynyilvánítási szabadság magasabb szintü oltalmát élvezi”. ${ }^{128}$ A családi kapcsolatokról való beszámoló vonatkozásában az AB is a sajtó tájékoztatáshoz füződő feladatának tulajdonított nagyobb súlyt a magánszféra védelmével szemben. ${ }^{129}$

A 3308/2020. (VI. 24.) AB határozat indítványozója egy gyermekek üdültetésére létrejött alapítvány főtitkára volt, akiről egy cikket tettek közzé, illusztrációként fotó- és videófelvételt is közölve az általa bérelt luxusvilláról, annak kertjéről és egy kitakart rendszámú autóról. Az AB leszögezte, hogy „a sajtószabadság nem ad általános felhatalmazást más ingatlanjának fényképezésére". 130 Az otthon, a magánlakáshoz füződő jogok alkotmányosan védettek, az Alaptörvény VI. cikk (1) bekezdése által. De e rendelkezés nem magát az ingatlant, hanem az egyén magánszféráját védi. ${ }^{131}$ A közölt képek azonban nem ábrázoltak olyat, ami a magánélettel kapcsolatba hozható; a bérlemény tulajdonosa pedig már korábban hozzáférhetővé tette az ingatlan címét és az arról készült képeket. „Az indítványozó abban a tudatban választotta magánélete ideiglenes színhelyéül a nyaralót, hogy tudhatta, arról hozzáférhetők felvételek. Hasonló felvételek újbóli megjelenése miatt nem hivatkozhat magánéletének sérelmére." ${ }^{132}$

124 3214/2020. (VI. 19.) AB határozat.

125 [3209/2020. (VI. 19.) AB határozat [48] bek.

126 3209/2020. (VI. 19.) AB határozat [51]-[52] bek.

127 3209/2020. (VI. 19.) AB határozat [54] bek.

128 3209/2020. (VI. 19.) AB határozat, [57] bek.

129 3209/2020. (VI. 19.) AB határozat, [60] bek.

130 3308/2020. (VI. 24.) AB határozat [34] bek.

131 3308/2020. (VI. 24.) AB határozat [36] bek.

132 3308/2020. (VI. 24.) AB határozat [36] bek. 


\section{5. „Politikai” beszéd}

A „politikai” beszédnek ezen áttekintésben azt tekintjük, amikor valamely sajátos helyzetből fakadóan kizárólag politikusok, illetve politikai pártok tehetik közzé véleményüket, amely mások - elsősorban más politikusok - jogait sérthetik; ilyenek a választási kampányban közzétett megnyilvánulások, a politikai reklámok a médiában és a parlamenti képviselők beszédei az országgyűlés plenáris vagy bizottsági ülésein.

\subsection{Véleményszabadság a választási kampányban}

A valódi alkotmányjogi panasz lehetőségének köszönhetően az AB-gyakorlat a választási kampányok során tett megszólalásokkal kapcsolatban is kialakulhatott. A 3122/2014. (IV. 24.) AB határozat alapjául szolgáló ügy kérelmezőjének politikai reklámfilmjét a médiaszolgáltató nem közölte. A filmben „egy katonai egyenruhába bújt majomnak öltözött ember szerepel, aki korábbi magyar miniszterelnökök hangjára tátog”. ${ }^{133}$ A Kúria álláspontja szerint „az állattal való azonosítás mindenkor dehumanizálja az érintett személyt, és ez az adott esetben alkalmas lehet az emberi méltóság megsértésére". ${ }^{134} \mathrm{Az} \mathrm{AB}$ - egyetértve a Kúriával - azt fejtette ki, hogy „[a]z Alaptörvény által védett véleménynyilvánítás köre a közhatalmat gyakorló személyekkel, valamint a közszereplő politikusokkal kapcsolatos vélemények esetében tágabb, mint más személyeknél, az emberi méltóságuknak az ő esetükben is van egy olyan lényegi, érinthetetlen magja, amelyet az esetleges kritikát megfogalmazó személyek is kötelesek tiszteletben tartani. Jelen választási ügyben az érintetteknek állatokként történő, megalázó módon megvalósított ábrázolása ezt a lényegi tartalmat - és ezzel az Alaptörvény II. cikkét és a IX. cikk (4) bekezdését - sérti meg."135

Álláspontom szerint vitatható, hogy az ügyben szereplő ábrázolás megvalósítottae az emberi méltóság sérelmét. A Kúria és $a z A B$ döntése sem tér ki arra a kérdésre, hogy a szatíra, paródia mennyiben élvezi a véleményszabadság védelmét. Kétséges, hogy önmagában az a körülmény, hogy közéleti szereplők képletesen állatok „bőrébe bújnak”, „állattal való azonosításként” értelmezhetö-e, aminek megítélése az ügy lényegét érinti, ezért bővebb kifejtése indokolt lett volna. A választási kampány időszakában a közéleti szereplőknek türniük kell a kemény, olykor szélsőséges kritikát. Azt józan ésszel senki nem gondolhatja, hogy az érintett kiemelt közéleti szereplőket a film készítôi nem tekintik a homo sapiens fajába tartozóknak, így a film, bár szó szerinti értelmezéssel valóban állatokként ábrázolt közszereplőket, paródiajellege miatt nem valósíthatta meg „az érintett személy emberi státuszának teljes, nyilvánvaló és súlyosan becsmérlő tagadását".136

133 3122/2014. (IV. 24.) AB határozat [2] bek.

134 3122/2014. (IV. 24.) AB határozat [3] bek.

135 3122/2014. (IV. 24.) AB határozat [17] bek.

136 3122/2014. (IV. 24.) AB határozat [62] bek. 
A tényállítások és a vélemények elhatárolásához is fontos adalékul szolgál a választási kampányokban közzétettekkel kapcsolatban formálódó bírósági és alkotmánybírósági gyakorlat, amely ráadásul kapcsolódást mutat a Ptk. vonatkozásában kialakuló alkotmányos értelmezéshez. A 31/2014. (X. 9.) AB határozatban a testület magától értetődően vette alapul a közszereplők személyiségvédelme kapcsán kialakult gyakorlatát: „Választási kampányban tipikusan a közszereplők egymás közti kontextusában kell értelmezni és megítélni a véleménynyilvánítási szabadságot, illetve annak korlátait."137 Ez a megközelítés vitatható; a 2013. évi XXXVI. törvény a választási eljárásról (Ve.) 2. $\mathbb{\$}(1)$ bekezdés $e$ ) pontja „jóhiszemü és rendeltetésszerü" joggyakorlást ír elö, azaz a szóban forgó ügyekben ennek mércéjét szükséges megtalálni (mikor lehet jóhiszemủen valótlan állítást tenni, elvben lehetséges-e szélsőséges, bántó véleményt jóhiszemủen közzétenni, illetve melyek a rendeltetésszerű joggyakorlás keretei egy választási kampányidőszakban).

A személyiségi jogok védelmével kapcsolatban kialakult mércék más tényállások alkalmazásával függenek össze, így nem magától értetődő, hogy a Ve. kontextusában is irányadók lehetnek. Ugyanakkor nem meglepő, hogy a Kúria és az AB is ezekhez nyúlt, tekintettel arra, hogy a tényállásokban több analógia fedezhető fel, például ami a közszereplők érintettségét, a tényállítások és vélemények szükséges elhatárolását és a közügyek vitatását illeti. A konkrét ügyben az $\mathrm{AB}$ lényegében felülbírálta az ítélötáblát: „A bírói döntés azt sem vette figyelembe, hogy a panaszos véleményként fejtette ki mondandóját. Az értékítélet, illetve a tényállítás közötti különbségtételnek úgyszintén lehet alkotmányossági relevanciája. [...] A véleménynyilvánítás szabadsága tehát fokozottan érvényesül olyan értékítéletekkel kapcsolatban, amelyek a közügyekre vonatkozó vélemények ütközésében kapnak hangot, még akkor is, ha esetleg túlzók és felfokozottak."138

$\mathrm{Az} A B$ döntésében meghatározhatta volna a tényállítások és a vélemények elhatárolásának alkotmányos kereteit. A választék ráadásul nem szủkül le a tényállítás és a vélemény kettősére, ezért ennél differenciáltabb megközelítésre van szükség, és el kell határolni egymástól a tényállításokat (ezek lehetnek valósak és valótlanok), a vizsgálható ténybeli alappal rendelkező véleményeket (amelyek ténybeli alapja lehet valós vagy valótlan), valamint a teljesen szubjektív, ténybeli alappal nem rendelkező véleményeket, értékítéleteket.

Az 5/2015. (II. 25.) AB határozat indítványozója egy, a budapesti Kossuth téren tartott demonstráción magát egy időközi országgyűlési választás egyedüli baloldali jelöltjének nevezte. Szó szerint azt mondta: „A Fidesznek van 11 jelöltje, 11 különböző mezben. Kamu jelöltekkel és az ellenzéki szavazók megosztásával és készülő kalandorokkal állt fel a Fideszes csapat. [...] Február 22-én le fogom győzni a Fidesz jelöltjeit Veszprémben." Az ügy eldöntésének alkotmányos hátterét ezúttal is a közszereplők hírnév- és becsületvédelmére vonatkozó 36/1994. (VI. 24.) és 7/2014. (III. 7.) AB határozat adta. Az AB ezúttal is a bíróságtól eltérően ítélte meg a közzétettek tényállítás-

137 31/2014. (X. 9.) AB határozat [28] bek.

138 31/2014. (X. 9.) AB határozat [29]-[30] bek. 
vagy véleményjellegének kérdését: „A jelen ügyben vizsgált bírói döntés ugyanakkor, megragadva a kijelentés direkt tartalmánál, nem vette figyelembe, hogy az indítványozó véleményként fejtette ki mondandóját." ${ }^{139} \mathrm{Az}$ AB helyesen ítélte meg azt, hogy a szóban forgó kijelentés vélemény, és a leírtakat nem szó szerinti jelentésük alapján kellett értelmezni: nyilvánvaló, hogy egy párt nem állíthat 11 különböző - egymással is versengő - jelöltet egyazon választókörzetben. De a tényállítások és a vélemények elhatárolásának szempontjait az AB döntése nem határozta meg.

Egy másik ügyben egy jelölő szervezet közösségi oldalán osztott meg egy videót, amely szerint az országgyủlési időközi választás egyik rivális jelöltje, aki a MAL Zrt. felügyelö bizottságának tagja volt a vörösiszap-katasztrófa bekövetkeztekor, felelős lehet a balesetért. A videó szerint „[a] cég vezetői között ott ült P. F., továbbá „P. F. dolga az lett volna, hogy megakadályozza a katasztrófát, de ő semmit sem tett”. ${ }^{140}$ A Kúria valótlan tényállításnak minősítette az elhangzottakat, részletesen, jogszabályi hivatkozások kíséretében kifejtve, hogy egy felügyelőbizottsági tag nem tekinthető az adott cég „vezetőjének”. Az AB határozatában ezt elutasítva véleménynek minősítette a videóban elhangzottakat. ${ }^{141}$

Az 5/2015. (II. 25.) AB határozat esetében jelzett kritika itt is érvényes. A tényállítások és a vélemények elhatárolásának alkotmányos szempontjait a határozat nem azonosítja, és az sem érthető teljesen, hogy miért tekinti véleménynek az $\mathrm{AB}$ az adott kijelentést (megítélésem szerint tévesen). Kétségtelen, hogy bizonyos esetekben a tényállítások és a vélemények elhatárolása nehéz, és szükségszerűen szubjektív döntést is feltételez, de az $\mathrm{AB}$ döntésében magyarázatot kellett volna adni a bíróságokétól eltérő értelmezés okaira, annál is inkább, mert ebben a döntésében a Kúria igyekezett valóban indokolni az elhangzottak tényállításként való értelmezését.

A 3107/2018. (IV. 9.) AB határozat egy olyan választási szórólap nyomán született, amelyen a következő állítás szerepelt: „Az Ön képviselője, T. B. 2014 óta egyszer ejtette ki Fót nevét az Országgyủlésben." A kijelentés tényállítás- vagy véleményjellegével kapcsolatban az indokolás ezúttal részletes és megalapozott elemzést tartalmaz, kifejezetten a választási kampánybeli kommunikáció jellegzetességeire tekintettel.

„[A] politikai vitának a választási kampány során különösen is felfokozott körében a tényállítások meghatározása nem történhet önmagában a bizonyíthatósági teszt köznapi értelemben vett automatikus alkalmazásával, azaz nem szorítkozhat kizárólag a vizsgált kijelentés szó szerinti tartalmának értékelésére. A közügyek intenzív vitájában résztvevők jogi felelősségre vonásához nem elegendő annak kimutatása, hogy a vizsgált megszólalás bizonyos elemei ténylegesen, objektív módon cáfolhatók. A vitatott kijelentés értékelését arra is figyelemmel kell elvégezni, hogy a kijelentés a választási kampány speciális szituációjában milyen valódi jelentést hordoz a kampányüzenetek címzettjei, a választópolgárok számára. Ennek

139 5/2015. (II. 25.) AB határozat [27] bek.

140 9/2015. (IV. 23.) AB határozat [3] bek.

141 9/2015. (IV. 23.) AB határozat [43] bek. 
az értékelésnek a szemléletét az határozza meg, hogy a közügyek demokratikus vitája során a vita érintettjei a politikai történéseket a maguk összefüggéseiben értelmező polgárok, akik tisztában vannak a pártpolitikai véleménynyilvánítások, különösképpen a kampányolás figyelemfelkeltésre és túlzásokra hajlamos jellemzőivel. [...] Mindezzel összhangban kell dönteni arról, hogy az egyébként kijelentő módban megfogalmazott kijelentés az alkotmányjogi mérlegelésben valóban tényállításnak minősül-e. Ha a megnyilatkozásnak a közügyek vitája, kiváltképp a kampány sajátosságaira tekintettel észszerűen tulajdonítható olyan jelentés, amely szerint a közlést a választók az érintett múlt- vagy jövőbeli politikájára vagy a jelölt alkalmasságára vonatkozó politikai véleményként (nem pedig szó szerint) értelmezik, akkor a közéleti vita legintenzívebb szférájának szabad alakulása érdekében ebből kell kiindulni." ${ }^{142}$

Egyértelmü, hogy a közügyek vitájának szabadsága a tényállítások és vélemények elhatárolása rugalmas, a közbeszéd állapotát figyelembe vevő, az elhangzott kijelentés kontextusára is figyelő döntést igényel az egyedi ügyekben. Választási ügyekben hoszszabb távon pedig érdemes lenne végiggondolni, hogy a Ve. alkalmazásakor a közügyek vitájára általánosan érvényes személyiségvédelmi szabályok analógiája igazolható-e, vagy lehetséges olyan sajátosságokat azonosítani egy választási (népszavazási) eljárás kapcsán, amelyek indokolják az azoktól való eltérést. Ez a feladat nem könnyü, mert kézenfekvőnek mutatkozik az analógia alkalmazása, mivel itt is, ott is közéleti szereplők érintettek, és közügyekről - sőt a legerőteljesebben vitatható közügyekről, egy választási eljárásban folyó vitákról - van szó, ahol a felek tényállításokat tesznek és véleményeket fogalmaznak meg. Ezzel együtt a Ve. által elvárt jóhiszeműségi mérce és a rendeltetésszerű joggyakorlásra vonatkozó követelménynek a személyiségvédelmi szabályokra vonatkozó alkotmányos elvárásokkal összeférő, de azzal nem teljes egészében azonos értelmezése elvben nem elképzelhetetlen. Csak egy példa a lehetséges eltérésre: még a szükséges gondosság tanúsítása ${ }^{143}$ esetén is felhozhatók érvek a valótlan tényállítások védelmével szemben, mert azok a Ve. kontextusában nem személyiségi jogsértést, hanem a választók félrevezetését eredményezik. ${ }^{144}$

\subsection{Véleményszabadság és a politikai reklám szabályozása}

Az 1/2013. (I. 7.) AB határozat megállapította, hogy a választási eljárásról szóló, 2012-ben elfogadott, de ki nem hirdetett törvény azon rendelkezése, amely szerint választási kampányidőszakban kizárólag közszolgálati médiaszolgáltatásban tehető

142 3107/2018. (IV. 9.) AB határozat [28]-[29] bek.

143 Lásd: 36/1994. (VI. 24.) AB és 7/2014. (III. 7.) AB határozatok.

144 Az AB gyakorlatának elemzésére nézve lásd: Tóth J. Zoltán: A véleménynyilvánítási szabadság érvényesülése és érvényesítése a választási eljárásokban: az Alkotmánybíróság gyakorlata a választási ügyben hozott bírói döntéssel szembeni alkotmányjogi panasz alapján indult ügyekben. Jogtudományi Közlöny, 71. (2016), 1. 1-18. 
közzé politikai reklám, azaz amely minden más médiaszolgáltatásban megtiltja a politikai kommunikáció e fajtáját, alaptörvény-ellenes, mert azzal a következménnyel járna, hogy a politikai reklámozás lehetősége éppen a társadalomhoz legszélesebb körben eljutó médiumok esetében szűnik meg. E korlátozásnak az $\mathrm{AB}$ nem találta meg az Alaptörvénnyel összeférő indokait. ${ }^{145} \mathrm{Az}$ ezt követően elfogadott új szabályozás, a Ve. ezen alkotmányossági problémákat orvosolta, a politikai reklámok kötelező ingyenessége pedig az Alaptörvény IX. cikk (3) bekezdésébe is bekerült.

\subsection{Parlamenti szólásjog}

$\mathrm{Az}$ AB gyakorlata kiterjed a parlamenti képviselők szólásszabadságát korlátozó intézkedések alkotmányossági vizsgálatára is. ${ }^{146}$ A 2012. évi XXXVI. törvény az Országgyűlésről (Ogytv.) a parlament tárgyalási rendjének fenntartása, az ülések zavartalan lefolytatásának biztosítása és az egyes személyek, közösségek méltóságának védelme érdekében a plenáris vagy a bizottsági ülést vezető elnök számára fegyelmi jogköröket biztosít. ${ }^{147}$

A parlamenti szólásjogot korlátozó törvényi előírásokkal az AB két döntésében foglalkozott, és az egyes rendelkezések alaptörvény-ellenességének megállapítására irányuló alkotmányjogi panaszokat elutasította. ${ }^{148} \mathrm{~A}$ parlamenti szólásjog mint a véleményszabadság sajátos célú és formájú gyakorlása tekintetében az $\mathrm{AB}$ megállapította, hogy „[a] szabad véleménynyilvánítás érvényesülésének kiemelten fontos helyszíne az Országgyűlés, az a terep, ahol az ország sorsát közvetlenül érintő ügyekben érvek és ellenérvek felsorakoztatását követően döntést hoznak a képviselők". ${ }^{149} \mathrm{~A}$ képviselői szólásszabadság korlátozhatósága kapcsán ugyanakkor az AB megközelítése szerint „különbséget kell tenni a véleménynyilvánítás szabadsága és a véleménynyilvánítás megjelenésének formája, módja között. [...] [A]z Országgyűlésnek jogában áll olyan (ön)korlátozó rendelkezéseket alkotni, amelyek garantálják a testület méltóságát és zavartalan működését." ${ }^{150}$

145 1/2013. (I. 7.) AB határozat [92]-[100] bek. A határozat elemzését lásd: Badó-Lovassy-Téglási (2019) i. m. 444-449.

146 A parlamenti képviselők szólásjogának emberi jogi jellegéről az EJEB által eldöntött magyar ügyek összefüggésében lásd: Szente Zoltán: Emberi jogok-e a parlamenti képviselői jogok? A képviselöi szólásszabadság alkotmányjogi jellegéről. Állam-és Jogtudomány, 56. (2015), 2. 74-90.

147 Ogytv. 45-52/H. \$.

148 3206/2013. (XI. 18.) AB és 3207/2013. (XI. 18.) AB határozatok. A döntésekről lásd: Smuk Péter: Ostrom vagy felújítás alatt? A véleményszabadság új határai. Közjogi Szemle, 6. (2013), 2. 25-34.

149 3206/2013. (XI. 18.) AB határozat [21] bek.

150 3206/2013. (XI. 18.) AB határozat [25]-[26] bek. Megjegyzendő, hogy az Ogytv. rendelkezéseinek alkalmazásával összefüggésben több magyar vonatkozású EJEB-döntés is született, amelyek a képviselőkkel szembeni fegyelmi intézkedések alkalmazását az Egyezmény 10. cikkével ellentétesnek minősítette, lásd: Karácsony and Others v. Hungary, no. 42461/13, 2014. szeptember 16-i ítélet; Szél and Others v. Hungary, no. 44357/13, 2014. szeptember 16-i ítélet, illetve a két ügyben született összevont nagykamarai döntést 2016. május 17 -én, továbbá lásd: Szanyi v. Hungary, no. 35493/13, 2016. november 8-i ítélet. A Karácsony- és a Szél-ügyek elemzéséről lásd: Smuk Péter: Az Emberi Jogok Európai Bíróságának határozata az Országgyűlés fegyelmi intézkedéseiről. Jogesetek 


\section{A gyülöletbeszéd korlátozása}

A valamely közösséggel, személyek csoportjával szembeni gyülölködő megnyilvánulásokat összefoglaló „gyülöletbeszéd” problémáját a jogrendszer komplexen kezeli. Idetartozik több büntetőjogi tényállás, ${ }^{151}$ a médiaszabályozásban szereplő gyülöletkeltés és a kirekesztés tilalma, ${ }^{152}$ valamint a Ptk.-ban rögzített magánjogi tilalom. ${ }^{153}$ A közösség elleni uszítás tényállásával összefüggésben 1992 és 2008 között született négy különböző $A B$-döntés alaposan leszűkítette az utat a jogalkotás számára, ${ }^{154}$ feltehetően ezért is nyitott a jogalkotó a polgári jog felé. Az önkényuralmi jelképek használatának és a népirtások tagadásának tilalma összességében a közéleti viták szabadsága szempontjából marginálisabb kérdések, de az $\mathrm{AB}$ általi megítélésük fontos elemekkel gazdagíthatja a véleményszabadság alkotmányos doktrínáját.

\subsection{Az Alaptörvény és a Btk. módosítása}

A Btk. az elfogadásakor csak kisebb korrekciókat végzett a „közösség elleni izgatás”155 korábbi tényállásán. A bűncselekményhez füződő joggyakorlat sem gyarapodott, és 2008 óta az AB sem hozott új büntetőjogi gyülöletbeszéd-döntést. Az első ilyen, a 30/1992. (V. 26.) AB határozat alapján gyülöletre uszítás miatt azok a gyülölködő kifejezések voltak büntethetők, amelyek aktív, ellenséges magatartás, indulat felkeltésére alkalmasak. A gyülölet felkeltésének szándéka irreleváns, és az sem kell a büncselekmény megvalósulásához, hogy a tényállásban elkövetési magatartásként szereplő „uszítás” kifejezetten „tevékeny gyülöletre” mozgósítson, de az elkövető tudatának át kell fognia azt, hogy magatartása eredményeképpen erőszakos cselekményeket követhetnek el. Az AB később, a 18/2004. (V. 25.) AB és a 95/2008. (VII. 3.) AB határozataiban úgy döntött, hogy - hasonlóan az amerikai szövetségi Legfelső Bíróság által kidolgozott clear and present danger doktrína ${ }^{156}$ lényegéhez - kizárólag „az erőszakcselekmény nyilvánvaló, közvetlen veszélyével és az egyéni jogok sérelmével fenyegető cselekmények" ${ }^{157}$ büntetőjogi szankcionálását tekinti alkotmányosan megengedettnek. A szigorú mércéből fakadóan a gyülölködő megnyilvánulások a büntetőjog által jobbára érinthetetlennek bizonyultak.

Magyarázata, 6. (2015), 1. 63-68.; Kazai Viktor Zoltán: Strasbourgi manifesztum a liberális demokrácia védelmében. Fundamentum, 19. (2015), 2-3. 95-106.

151 A közösség elleni uszítás (Btk. 332. \$), az önkényuralmi jelkép használata (335. \$), a nemzetiszocialista vagy a kommunista rendszerek büneinek nyilvános tagadása (333. \$) és a nemzeti jelkép megsértése (334. \$).

152 Smtv. 17. $\$(1)-(2)$ bek.

153 Ptk. 2:54. $\$(5)$ bek.

154 Lásd: Koltay András: A nagy magyar gyülöletbeszéd-vita: a „gyülöletre uszítás” alkotmányos mércéjének azonosítása felé. Állam-és Jogtudomány, 54. (2013), 1-2. 91-123.

155 A Btk.-ban módosult néven: „közösség elleni uszítás”, 332. \$.

156 Lásd: Koltay András: A „clear and present danger” elv fordulatos története az Egyesült Államokban és Magyarországon. Magyar Jog, 56. (2009), 7. 418-423.

157 95/2008. (VII. 3.) AB határozat III.2.1. 
Az Európai Unió Tanácsának a rasszizmus és az idegengyülölet visszaszorítását célzó kerethatározata elvárja, ${ }^{158}$ hogy az EU tagállamai egységesen tilalmazzák a közösségek ellen irányuló erőszakra vagy gyűlöletre izgatást. A kerethatározat elfogadását követően nyolc évvel később, 2016-ban született törvénymódosítás eredményeképpen a Btk. hatályos rendelkezései büntetni rendelik nemcsak a csoportok, hanem az egyes csoportok tagjai elleni - a csoporthoz tartozásukra tekintettel való - elkövetést, illetve ami ennél fontosabb, az elkövetési magatartás a „gyűlöletre uszításon” túl kiegészült az „erőszakra uszítással”. Amennyiben a korábban a "gyủlöletre uszítás” magatartásával kapcsolatban kialakult értelmezéseket jövőben az „erőszakra uszítás” elkövetési magatartására kell alkalmazni - erre utal a Btk.-módosítás javaslatához füzött indokolás -, akkor kérdéses, hogy a „gyülöletre uszításnak” a joggyakorlat milyen új értelmezést fog adni, és miként határolja majd el azt az „erőszakra uszítástól”.

\subsection{A polgári jogi gyülöletbeszéd-tilalom}

Mivel a büntetőjogi gyűlöletbeszéd-tilalom alkotmányos értelmezése lényegében elzárta az utat a gyűlölködő megnyilvánulások büntetése elől, már 2013 előtt is több ízben felmerült annak a lehetősége, hogy a polgári jog területén szülessen olyan szabály, amely a gyűlöletbeszéddel szemben alkalmazható. ${ }^{159} \mathrm{~A}$ Ptk.-ban egy ezt célzó rendelkezés is szerepel. ${ }^{160} \mathrm{~A}$ tényállás azt célozza, hogy meghatározott közösségre nézve sértő megnyilvánulások esetén a közösség bármely tagja számára lehetővé tegye - saját személyiségi jogai megsértésére hivatkozva - a perindítást. Azaz a Ptk. úgy tekinti, hogy a tényállásban rögzített „nagy nyilvánosság előtt súlyosan sértő vagy kifejezésmódjában indokolatlanul bántó jogsérelem", amely egy közösséggel szemben fogalmaz meg véleményt, az egyén személyiségi jogainak megsértését okozhatja. A polgári jogi személyiségvédelem rendszeréből kilógó megoldás ez, de mivel az egyén sérelme a személyiségi jogok körében mindenféleképpen objektivizált mércék alapján ítélendő meg, azaz jórészt eltávolodik a jogorvoslatot kereső egyén tényleges (szubjektív) sérelmétől, végeredményben nem feltétlenül megengedhetetlen dogmatikai bakugrás az, ha a közösség megtámadása esetében a törvény lehetővé teszi a közösségbe tartozó egyén sérelmének megállapítását. Hiszen a konkrétan azonosítható egyén személyiségi jogi sérelme is egy személyes adottságaitól, képességeitől, helyzetétől jórészt elválasztott mérce alapján nyer védelmet, aminek nem feltétlenül lesz szoros kapcsolódása hozzá mint felpereshez. Tehát a sérelem megtörténtének vizsgálatakor a bíróságnak hasonló szempontokat kell mérlegelnie az egyéni becsület és a közösség sérelmére való felperesi hivatkozáskor: alkalmas volt-e a közlés a sérelemokozásra

158 A Tanács 2008/913/IB kerethatározata (2008. november 28.) a rasszizmus és az idegengyülölet egyes formái és megnyilvánulásai elleni, büntetőjogi eszközökkel történő küzdelemről.

159 Lásd: Koltay András: A gyülöletbeszéd korlátozása a magyar jogrendszerben. In Koltay András (szerk.): A gyülöletbeszéd korlátozása Magyarországon. Alkotmányos és jogalkalmazói megközelitések, európai kitekintéssel. Budapest, CompLex, 2013. 157-172.

160 Ptk. 2:54. $\$(5)$ bek. 
(„átsugárzott-e” a közösséget ért támadás az egyénre), illetve a közlés az alkotmányosan védett vélemények közé tartozik-e?

A Ptk.-tényállás alkotmányossági aggályokat is felvető értelmezési nehézségeiről máshol részletesen írtam, ezek összefoglalása meghaladná a jelen írás kereteit. Összességében fenntartom, hogy a tényállásnak több olyan tisztázatlan eleme van, amely alapot adna az alaptörvény-ellenesség megállapítására. ${ }^{161}$ Ezzel együtt is lehetséges olyan kapcsolódó joggyakorlat kialakítása, amely a konkuráló alkotmányos jogok között megfelelő egyensúlyt talál. Ilyen döntéseknek tekinthetők az azonos napon kihirdetett két „blaszfémia”-határozat.

A 6/2021. (II. 19.) AB határozat előzményi ügye 2016-ra datálódik, amikor is a budapesti lengyel nagykövetség előtt tüntetés szerveződött a lengyel abortusztörvény ellen, amelyen a résztvevők egyike püspöki jelmezben „Járuljatok szentáldozáshoz!” felhívást intézett a jelenlévőkhöz, majd áldoztató papi tevékenységet imitálva, egy jól láthatóan címkézett, „abortusztabletta” feliratú zacskóból, „Krisztus teste” kijelentés kíséretében, fehér tablettákat helyezett az elébe járulók nyelvére. ${ }^{162} \mathrm{~A}$ Kúria (és a Törvényszék) döntése az előadást is a véleményszabadság védett körébe utalta, de az $\mathrm{AB}$ megsemmisítette a bírósági ítéleteket.

A testület döntése szerint a vizsgált cselekmények ugyan a katolikus egyházzal szembeni állásfoglalásként jelentek meg, de azok nemcsak az egyháznak a közéleti kérdésekben aktív, hanem a nyilvánosság előtti vitában részt nem vevő tagjait is sérthette. Egy vallási közösség tagjai méltóságának védelme nem korlátozható az adott vallási közösség közszereplést vállaló képviselőinek személyiségi jogainak korlátozásához hasonló módon. Amint azt az $\mathrm{AB}$ rögzíti, még a közszereplő politikusokat is megilleti a személyiségvédelem, ha az értékítélet a személyüket magán- vagy családi életükkel kapcsolatban érinti; ${ }^{163}$ "ehhez hasonlóan a vallási közösségek tagjai sem kötelesek a közösségük hitelveit, szertartásait és gyakorlatait - a közügyek vitatásától függetlenül, öncélúan - sértő vagy bántó közléseket eltürni”.164

Egy fontos kérdésben a testület indokolása vitatható: $\mathrm{az} A \mathrm{AB}$ felrója az eljáró bíróságoknak, hogy nem vizsgálták meg azt a kérdést, miszerint a performansz egyáltalán véleménynek, illetve valamely közügy megvitatásának tekinthető-e. ${ }^{165} \mathrm{E}$ felvetésben implicite benne foglaltatik a nemleges válasz lehetősége is. Megítélésem szerint ezzel szemben egy, a performansz véleményjellegére irányuló alapos vizsgálatnak e kérdésekre mindenképpen igennel kell válaszolnia, azaz a magatartás a véleményszabadság

161 Lásd: Koltay András: A gyülölet magánjogi korlátozása. A Ptk. és a gyakorlat kezdeti tapasztalatai. In Molnár Gábor Miklós - Koltay András (szerk.): Bonus iudex. Ünnepi tanulmányok Varga Zoltán 70. születésnapja alkalmából. Budapest, Kúria - Pázmány Press, 2018. 197-225. A Ptk.-tényállás kritikájára nézve lásd továbbá: Gárdos-Orosz Fruzsina - Pap András László: Gondolatok a gyűlöletbeszéd polgári jogi szabályozásának jogi és jogpolitikai környezetéről. Állam- és Jogtudomány, 55. (2014), 2. 3-26.; Gárdos-Orosz Fruzsina: Az új polgári jogi gyülöletbeszéd-szabályozásról. Fundamentum, 14. (2013), 3. 21-38.

162 6/2021. (II. 19.) AB határozat [2] bek.

163 Lásd: 7/2014. (III. 7.) AB határozat.

164 6/2021. (II. 19.) AB határozat [34] bek.

165 6/2021. (II. 19.) AB határozat [34]-[36] bek. 
hatályán belül helyezkedik el, de ebből még természetesen nem következik az, hogy ne lenne korlátozható.

A 7/2021. (II. 19.) AB határozat kiindulópontja a $H V G$ címü hetilap 2014. évi karácsonyi címlapja, amely a „Nagy Harácsony” felirattal jelent meg, rajta pedig vezető politikusok képmásai egy 17. századi németalföldi festmény módosított változatán voltak láthatók. A címlapkép Gerard van Honthorst $A$ pásztorok imádása címet viselő festményének felhasználásával készült, és eredetileg Máriát, az újszülött Jézust ábrázolta a pásztorok társaságában; a karikatúra a képbe beillesztett kormányzati politikai szereplők anyagi javakat hajszoló jellemére kívánhatott utalni.

A címlap ügyében az utolsó bírósági döntést hozó Kúria elutasította a kérelmet, és megállapította, hogy a vizsgált tartalom a véleményszabadság által védett, és a keresztény hívek személyiségi jogait nem sértette. Az AB jóváhagyta az e döntés mögötti szempontrendszer megalapozottságát, és ennek megfelelően elutasította a bírósági ítélet megsemmisítését kezdeményező alkotmányjogi panaszt. A testület is politikai, nem pedig a vallást kritizáló véleményt látott a címlapban. ${ }^{166}$ Döntése szerint a tartalom nem irányult a keresztények megsértésére, a vallási jelképrendszer felhasználása a politikai véleménynyilvánításra pedig nem eleve jogellenes. ${ }^{167}$ Megjegyzendő persze, hogy a híveket az elsődlegesen valóban politikai véleményként megjelenő tartalom e jellegétől függetlenül is sérthette, de e szempont figyelembevételéből sem szükségszerủen következik az, hogy a konkrét politikai vélemény korlátozható lenne.

A 7/2021. (II. 19.) AB határozat megjegyzi, hogy a sértő vagy bántó beszédre nem elsősorban a peres eljárás kezdeményezése, hanem a még több beszéd, azaz a bántalomra adott reakció, vita a kézenfekvő válasz. ${ }^{168}$ Ezzel a megközelítéssel, valamint a szabadság és a méltóság védelme közötti egyensúlyteremtést célzó két $A B$ döntés lényegi érvelésével egyetértünk. A demokrácia fontos értéke, hogy az egyes közösségek, így az egyházak is kiléphetnek a közéletbe, hallathatják hangjukat, részt vehetnek a vitákban, állást foglalhatnak fontos kérdésekben, mint amilyen például az abortusz megengedettsége és korlátai. Ha az egyház vagy hívei jogaikkal élve kilépnek a nyilvános térbe, akkor vállalniuk kell az ebből fakadó, rájuk nézve hátrányos következményeket is. Aki közéleti szerepet vállal - az egyházak pedig ezt teszik, állást foglalnak közéleti kérdésekben, helyesen -, annak a bántó, sértő, megalapozatlan kritikát is türnie kell. De ha az a nyilvánosságba ki nem lépő hívő jogait is hátrányosan érinti, akkor a véleményszabadság korlátozása már nem megengedhetetlen. A tüntetésen előadott performansz jogi megítélése a kritikával kapcsolatos tűrési kötelezettség határait mutatja meg. A címlapkép pedig ahhoz képest ilyen fokú sérelmet nem valósított meg, az közszereplők - a mai közbeszéd megszokottá vált extremitásaihoz képest nem is túl szélsőséges - kritikájának tekinthető. A vallásos tartalom ez utóbbinál csak eszköz volt, és nem maga a céltábla.

166 7/2021. (II. 19.) AB határozat [37] bek.

167 7/2021. (II. 19.) AB határozat [41] bek.

168 7/2021. (II. 19.) AB határozat [40] bek. 
A hetilapcímlapra vonatkozó döntést éles vita előzhette meg a testületben, erre utal az, hogy öt alkotmánybíró is különvéleményt füzött a többségi indokoláshoz, azaz a Kúria döntésének megsemmisítését látta volna helyesnek. Többen közülük az Alaptörvény Nemzeti Hitvallásának azon részletére hivatkoztak, amely a kereszténység történelmi szerepére utal. E szerep elismerése - amely végeredményben egy tény, mégpedig a magyar államiság szempontjából alapvető fontosságú tény rögzítése - és a vallási érzékenységet is sértő kritikus vélemények védelme azonban egyáltalán nem összeegyeztethetetlen. Mint Schanda Balázs alkotmánybíró párhuzamos indokolásában megjegyzi, a címlapkép maga ad bizonyítékot arra, hogy Magyarországnak van keresztény kultúrája, mert ellenkező esetben a kép tartalma értelmezhetetlen lenne. ${ }^{169}$

\subsection{Az önkényuralmi jelkép használatának tilalma}

Bár a 14/2000. (V. 12.) AB határozat alkotmányosnak minősítette az önkényuralmi jelképek használatának általános tilalmát rögzítő Btk.-tényállást, a későbbi sorozatos pervesztességek az EJEB előtt ${ }^{170}$ arra indították a testületet, hogy - miután egy alkotmányjogi panasz arra alkalmat adott - átértékelje a korábbi álláspontját.

A 4/2013. (II. 21.) AB határozatban a testület újból megvizsgálta az 1978-as Btk. 269/B. $\mathbb{S}$ (az önkényuralmi jelképek használatát tiltó rendelkezés) alkotmányosságát, és ezúttal, a korábbi határozatával ellentétesen, megsemmisítette a tényállást. A testület úgy vélte, hogy a bűncselekmény alkotmányossági szempontú megítélését önmagában az, hogy a 14/2000. (V. 12.) AB határozat ezt célozta, még nem tette ítélt dologgá, mert a körülmények megváltozása - elsősorban a Vajnai v. Hungary ügyben született EJEB-döntés, másodsorban a kialakult, nem egészen következetes büntetőbírósági gyakorlat - lehetővé teszi az újbóli vizsgálat elvégzését.

A döntés az alkotmányellenesség indokául a tényállás túlzott szélességét jelöli meg: „Az Alkotmánybíróság [...] megállapította, hogy a[z 1978-as] Btk. 269/B. \$ (1) bekezdése túl tágan határozza meg a büntetendő magatartások körét, mert nem differenciál, hanem a jelképhasználatot általában rendeli büntetni, jóllehet a célzat, az elkövetési módozat vagy a kiváltott eredmény figyelembevétele az egyes szimbólumok esetében elengedhetetlen lehet. A jelképhasználat általános büntetendővé nyilvánítása ahhoz vezet, hogy olyan magatartások is büntetendőnek minősülnek, amelyek bűncselekménnyé nyilvánítása aránytalanul korlátozza a véleménynyilvánítás szabadságát." ${ }^{171}$

A testület leszögezi, hogy az önkényuralmi jelképek használatának büntetőjogi korlátozása továbbra is indokolt, és döntésében szinte felhívta a jogalkotót egy

169 7/2021. (II. 19.) AB határozat [75] bek.

170 Lásd: Vajnai v. Hungary, no. 33629/06, 2008. július 8-i ítélet; Fratanoló v. Hungary, no. 29459/10, 2011. november 3-i ítélet; Vajnai v. Hungary (No. 2.), no. 6061/10, 2014. szeptember 23-i ítélet; Horváth and Vajnai v. Hungary, no. 55795/11 és 55798/11, 2014. szeptember 23-i ítélet; Noé, Vajna and Baló v. Hungary, no. 24515/09, 24539/09 és 24611/09, 2014. szeptember 23-i ítélet.

171 4/2013. (II. 21.) AB határozat V.2.2. pont. 
új, immár alkotmányosnak tekinthető tényállás megalkotására. Az újraszabályozás 2013-ban megtörtént. Azóta a Btk. 335. \$-a nem általában véve tiltja az önkényuralmi jelképek használatát, hanem csak akkor, ha az a köznyugalom megzavarására alkalmas, és ennek külön kiemelt esete az önkényuralmi rendszerek áldozatai emberi méltóságának vagy kegyeleti jogának sértése; azaz a jogalkotó az elkövetés módja és eredménye szempontjából szűkíti a korábbihoz képest a tényállás alkalmazhatóságát. ${ }^{172}$

\subsection{A népirtások tagadása}

A holokauszt és más népirtások, emberiség elleni büntettek tagadásának tiltása egyes súlyos bủntetteket, tragédiákat kiemel az emberiség történelmének szövetéből, és speciális védelmet nyújt az azokkal kapcsolatban ismerhető történelmi tények számára a megkérdőjelezésükkel szemben. Az EU Tanácsának már említett, a rasszizmus és az idegengyülölet visszaszorítását célzó kerethatározata ${ }^{173}$ kifejezetten elöírja az EU tagállamainak, hogy iktassák törvénybe az emberiség elleni büntettek vagy népirtások, illetve háborús büncselekmények tagadásának szankcionálását. A tényleges cél, a holokauszt tagadásának tilalma, átviláglik a szövegen, mivel az külön is említi a II. világháború lezárását követően, az 1945. augusztus 8-i Londoni Egyezmény által meghatározott, később a Nürnbergi Törvényszék által vizsgált - faj, bőrszín, vallási hovatartozás, etnikai vagy nemzetiségi eredet alapján elkövetett - bűncselekmények tagadását, jelentőségük csorbítását, amelyeket az EU tagállamaiban legfeljebb háromévi szabadságvesztéssel kell büntetni. Bár a kerethatározat lehetőséget ad a tagállam alkotmányos hagyományaira hivatkozással a kötelezettségek alóli kibújásra, Magyarország 2010-ben büntető törvénykönyvébe iktatta először a holokauszt tagadását, majd - a parlamenti választásokat követő gyors törvénymódosítást követően - a nemzetiszocialista vagy a kommunista rendszerek által elkövetett népirtás vagy más, emberiesség elleni cselekmények tagadását. ${ }^{174}$

$\mathrm{Az} A B$ a 16/2013. (VI. 20.) AB határozatában nem ítélte alkotmányellenesnek az 1978-as Btk. e rendelkezését: „[A] nemzetiszocializmus és a kommunizmus büneinek tagadása a véleménynyilvánítás szabadságával való olyan visszaélésnek tekintendő, ami nem csupán az áldozatok közösségének, de a velük közösséget vállaló, demokratikus értékek mellett elkötelezett állampolgárok méltóságát is súlyosan sérti. Az áldozatok hozzátartozói, az áldozatokkal közösséget vállaló személyek méltóságának védelme lehetővé teszi, illetőleg szükségessé teszi tehát az olyan cselekmény büntetőjogi szankcióval történő fenyegetését, amely a XX. századi totalitárius rendszerekben megtörtént tragikus és történelmileg meghatározó események tagadását valósítja meg."175

172 Az AB döntés elemzésére nézve lásd: Tóth J. Zoltán: Az önkényuralmi jelképek használata mint a véleménynyilvánítási szabadság korlátja? Jogelméleti Szemle, (2013), 2. 178-196.

173 A Tanács 2008/913/IB kerethatározata.

174 1978-as Btk. 269/C. \$, a hatályos Btk.-ban: 333. \$.

175 16/2013. (VI. 20.) AB határozat [50] bek. 
A testület tehát - a 14/2000. (V. 12.) AB határozathoz (az első önkényuralmi jelképhatározathoz) hasonlóan - a közösségek méltóságát jelölte meg védett jogi tárgyként, amelybe valamennyi, a „demokratikus értékek mellett elkötelezett állampolgár” beletartozik, tehát nem kizárólag a tényállásban megjelölt cselekmények áldozatai vagy azok hozzátartozói. Ezzel az AB megerősítette azon, 2000 óta formálódó gyakorlatát, miszerint a gyülöletbeszéd általános - és csak szigorú alkotmányos garanciák megléte mellett korlátozható - esetéhez képest léteznek speciális esetek, és ezek közé tartozik a vizsgált tényállás is; ez utóbbiak tekintetében a véleményszabadság alkotmányos védelme gyengébb lehet, mint a gyülöletbeszéd alapesetében. Az említett 2000-es és az e határozat indokolása közötti kapcsolat abban az értelemben figyelemre méltó, hogy a korábbi, 2000-es döntésének indokolását az ott vizsgált kérdés vonatkozásában a 4/2013. (II. 21.) AB határozat (a második önkényuralmijelkép-határozat) felülírta, azaz a korábbi érveket 2013-ban az utóbbi határozatban már maga a testület sem tartotta önmagában elégségesnek a szóláskorlátozás alkotmányos alátámasztására. Ettől függetlenül a 2000-es határozatból a 16/2013. (VI. 20.) AB határozat által idézett elvi tétel („alkotmányosan büntetőjogi korlátozás alá vonható a közösségek méltóságát sértő, köznyugalmat veszélyeztető magatartás is") érvényessége fenntartható.

A 16/2013. (VI. 20.) AB határozat az emberi méltóság (tehát az egyéni jogok) védelme mellett fontosnak tartotta a köznyugalom védelmét is. Az indokolás szerint:

„A XX. századi európai totalitárius rendszerek során az emberiség ellen elkövetett rémtetteket nem csupán a közvetlenül, avagy közvetett módon érintettek, de valamennyi, az alkotmányos értékeket elfogadó és tiszteletben tartó állampolgár megkérdőjelezhetetlen bűnnek tekinti és evidenciaként kezeli. Nem vitás ezért, hogy a fenti ténnyel és általános társadalmi meggyőződéssel ellentétes, nagy nyilvánosság előtt kifejezett álláspont, az igazságérzetet és az áldozatok méltóságát sértő vélemény arra is alkalmas lehet, hogy közfelháborodást keltve, másokat megbotránkoztatva olyan indulatot gerjesszen, amely a köznyugalom megzavarásához vezethet. Az Alkotmánybíróság megállapította, hogy az 1978-as Btk. 269/C. \$-a által büntetni rendelt magatartás magában hordozza a köznyugalom megzavarásának kockázatát is, az ilyen vélemények és álláspontok nyilvános artikulálásának korlátozását e körülmény is megalapozza, ezért szükséges."176

A határozat elkerüli annak a kérdésnek az alapos elemzését, hogy mi az elvi indoka a gyülöletbeszéd körébe tartozó egyes vélemények megkülönböztetésének, azaz mi indokolja ezek csekélyebb mértékű alkotmányos védelmét a gyülöletbeszéd alapesetéhez képest. „Az áldozatok közösségét” és „a velük közösséget vállaló, demokratikus értékek mellett elkötelezett állampolgárokat" ugyanis a gyűlöletbeszéd bármely megnyilvánulása ugyanúgy sértheti, és nem csak a speciális esetek megvalósulása. Másrészt míg az 1978-as Btk. 269. \$ vonatkozásában a köznyugalom súlyos veszélye

176 16/2013. (VI. 20.) AB határozat [52] bek. 
lenne csak - önmagában - a véleménykorlátozás alapja, a 16/2013. (VI. 20.) AB határozatban csak a köznyugalom megzavarásának elvi lehetőségét említik, igaz, nem a szóláskorlátozás egyetlen elvi alapjaként. ${ }^{177}$

\section{A médiaszabályozás gyakorlata}

Az Smtv. és a médiaszolgáltatásokról és a tömegkommunikációról szóló 2010. évi CLXXXV. törvény (Mttv.) számos rendelkezését - még az Alapörvény hatálybalépése előtt - alkotmányossági vizsgálat alá vette a 165/2011. (XII. 16.) AB határozat, ${ }^{178}$ azonban 2012 óta mindössze egyetlen eljárás indult az AB előtt valódi alkotmányjogi panasz nyomán.

A 3264/2016. (XII. 14.) AB határozat a médiaszabályozás egy összességében marginális jelentőségü szabályának alkotmányos értelmezését érintette. A kiegyensúlyozott tájékoztatás követelményén túl a médiaszabályozás arra vonatkozóan is előírást tartalmaz, hogy az egyes hír- és politikai tájékoztató műsorszámokban a bemutatásra szánt vélemények, értékelő magyarázatok közzétételére milyen keretek között kerülhet sor. Az Mttv. 12. $\mathbb{\$}(3)-(4)$ bekezdéseiben foglalt követelmények azt a célt szolgálják, hogy a közönség tagjai egy adott közéleti kérdésben ne csak a releváns álláspontok birtokában, hanem a médiaszolgáltató befolyásától is mentesen alakíthassák ki álláspontjukat. Ennek egyik módja, hogy a médiaszolgáltató közéleti, aktuális eseményekről való tájékoztatást tartalmazó műsorszámaiban rendszeresen szereplő személyek (bemondók, riporterek, műsorvezetők stb.) a politikai hírekhez saját véleményt, értékelő magyarázatot - a hírmagyarázat kivételével - nem fúzhetnek. Ezen elöírás ugyanakkor nem jelenti az egyes vélemények megjelenésének aránytalan korlátozását, ugyanis nem állít abszolút tilalmat a vélemények közzététele elé. Az Mttv. 12 . $\mathbb{\$}(4)$ bekezdése a médiaszolgáltatásban közzétett hírek és a vélemények, értékelő magyarázatok viszonyát, közzétételének módját szabályozza, megkövetelve, hogy amennyiben ilyen véleményt (értékelő magyarázatot) ismertetnek, az e minőség megjelölésével és szerzőjének megnevezésével, a hírektől megkülönböztetve jelenjen meg.

A Nemzeti Média- és Hírközlési Hatóság Médiatanácsa megállapította az Mttv. 12. $\$(3)-(4)$ bekezdéseiben foglaltak sérelmét arra tekintettel, hogy a médiaszolgáltató hírolvasója a Jobbik Magyarországért Mozgalmat „szélsőjobboldali” jelzővel illette. A Kúria helybenhagyó döntésével szemben a médiaszolgáltató alkotmányjogi panaszt nyújtott be. Az AB megállapítása szerint a Kúria nem alkalmazott olyan értelmezést, amely a sajtó- és a véleménynyilvánítási szabadságot a törvényi korlátokon túl, indokolatlanul megszorító értelmezést valósítana meg, ezért a panaszt elutasította. ${ }^{179}$ Ami a tények és a vélemények elhatárolási kérdését illeti, az $A B$ megítélése szerint

177 A kérdés európai kontextusba ágyazott tárgyalásához lásd: Smuk Péter: Az önkényuralmi rendszerek jelképei és a használatukat tiltó jogi szankciók rendszere. In Medias Res, 8. (2019), 2. 230-252.

178 Lásd: Koltay András - Polyák Gábor: Az Alkotmánybíróság határozata a médiaszabályozás egyes kérdéseiről. Jogesetek Magyarázata, 3. (2012), 1. 11-48.

179 3264/2016. (XII. 14.) AB határozat. 
azon jelzők használata minősülhet tényközlésnek, „amelyek tekintetében a társadalmi konszenzus olyan mértékü, amely esetben a tényjelleg megkérdőjelezhetetlen". Ezzel szemben a „politikatudomány és a köznyelv olyan minősítései, amelyek nem jelentenek egzakt kategóriákat, sem vitathatatlan tényeket, általában a személyes vélemény jellegével bírnak". ${ }^{180} \mathrm{Az}$ effajta, akár széles körben elterjedt jelzős szerkezetek alkalmazásának a közvélemény befolyásolására gyakorolt hatását tekintve a testület rögzítette, hogy „a közvélekedés időszakosan és körülményektől függően változó jelleget mutat, ezáltal a kialakult közvélekedésre is lehetséges erősítő vagy gyengítő hatást gyakorolni egy jelző - adott esetben akár ismétlő - hangsúlyozásával", ${ }^{181}$ ez pedig könnyen a hiteles és objektív hírszolgáltatás csorbulását okozhatja. A törvényi elöírás a hírösszefoglalókhoz történő véleményfüzéssel szemben messze nem fogalmaz meg teljes tilalmat, a „tudósítás az abban megjelenő vélemény közvetítése mellett is lehet tárgyilagos, ha a hír hallgatói számára nyilvánvalóvá válik, hogy az mint médiatartalom nem azonos a hír közlőjének véleményével”.182 Az egyedi ügy vizsgálatánál pedig a jogalkalmazónak (hatóság, bíróság) minden esetben figyelembe kell venni a jogszabály célját és a védendő értékeket, azaz a hiteles és tárgyilagos tájékoztatás követelményének érvényesülését.

Az ügy végül az EJEB-hez is eljutott, és a strasbourgi bíróság az ATV v. Hungary ügyben ${ }^{183}$ megállapította a 10 . cikk megsértését, a tények és a vélemények differenciálásának bizonytalanságára alapozva, amelyből fakadóan a kérelmező médiaszolgáltató nem láthatta előre cselekedete következményeit. ${ }^{184} \mathrm{Az}$ indokolás, mondjuk úgy, mondvacsinált, de világos, hogy az EJEB nem mulaszthatta el a lehetőséget az Európa-szerte sokat támadott magyar médiaszabályozás kritikájára, amikor - még ha egy ilyen apró jelentőségü ügyben is - végre alkalma nyílt állást foglalni annak tartalma felöl.

\section{A rémhírterjesztés tilalma}

A „koronavírus elleni védekezésről” szóló törvényjavaslat elfogadását követően 2020 tavaszán a Btk. is módosult, és egy második rémhírterjesztési tényállás került a törvénybe: „337. $\mathbb{\$}(2)$ Aki különleges jogrend idején nagy nyilvánosság előtt olyan valótlan tényt vagy való tényt oly módon elferdítve állít vagy híresztel, amely alkalmas arra, hogy a védekezés eredményességét akadályozza vagy meghiúsítsa, bủntett miatt egy évtől öt évig terjedő szabadságvesztéssel büntetendő."

Az AB 15/2020. (VII. 8.) AB határozatában úgy ítélte meg, hogy az új tényállás nem alaptörvény-ellenes, az általa használt fogalmak mindegyike az alkotmányos

180 3264/2016. (XII. 14.) AB határozat [47] és [52] bek.

181 3264/2016. (XII. 14.) AB határozat [56] bek.

182 3264/2016. (XII. 14.) AB határozat [53] bek.

183 ATV v. Hungary, no. 61178/14, 2020. április 28-i ítélet.

184 44-55. bek. 
követelményekkel összhangban lévő jelentéssel ruházható fel a jogalkalmazás során. ${ }^{185}$ A határozat részletekbe menően elemzi a szándékos elkövetés követelményét, azaz hogy pontosan mire kell az elkövető szándékának kiterjednie a valótlan tény közlésekor. ${ }^{186} \mathrm{Az}$ indokolás részletesen kitér a közéleti viták szabadságának kérdéseire is: „A tiltás [...] csak a tudottan valótlan (vagy elferdített) tényállításokra vonatkozik, kritikus véleményekre nem. Kiforrott joggyakorlat van arra vonatkozóan, hogy ezeket a védett vélemények körébe kell utalni, és mivel a járványügy jelenleg a legfontosabb közügyeink közé tartozik, ezért a tételes jogi normák keretei között a legszigorúbb védelmet kell az e tárgyat érintő közéleti viták számára biztosítani." ${ }^{187}$

A tiltás a tényállításoknak csak egy bizonyos körére vonatkozik. A védekezés eredményességét akadályozni képes (valótlan) információk köre relatíve szük, legalábbis jóval szúkebb, mint a különleges jogrend bevezetését indokló veszéllyel kapcsolatos valamennyi közzétett tényállítás. A tiltott cselekedetnek objektíve alkalmasnak kell lennie arra, hogy a védekezés - kormányzati vagy más állami, önkormányzati vagy akár magánszemélyek összefogásából származó cselekvés - eredményességét akadályozza vagy meghiúsítsa. ${ }^{188}$

A jogalkalmazás számára nyújtott segítségként a határozat alkotmányos követelményt rögzít, amely az érintett tényállások egy körére vonatkozik, és a véleményszabadság védelmét erősíti. Arról az esetkörről van szó, amikor a közlésben szereplő tényállítás igazságtartalma a közlés idején még nem állapítható meg, azonban utóbb hamisnak bizonyulhat: „[A] tényállás csak az olyan tény közlését fenyegeti büntetéssel, amelyről az elkövetőnek a cselekmény elkövetésekor tudnia kellett, hogy hamis, vagy amelyet maga ferdített el, és amely a különleges jogrend idején a védekezés akadályozására vagy meghiúsítására alkalmas." 189

\section{A tőkepiaci törvény és a véleményszabadság}

A valós tények közléséből eredő vitás jogi helyzetek nem csak a személyiségvédelem területén fordulhatnak elő - akár a piacfelügyeleti szabályok idevágó elemei is érinthetik a média szabadságát. Erre példa a 3/2015. (IV. 2.) AB határozat által érintett eset. Egy internetes sajtótermék „Norvégia is figyelheti a Hernádi-ügyet” címen megjelent cikke arról szóló tájékoztatást tartalmazott, hogy a MOL Nyrt.-ben 1,64\%-os tulajdonrésszel rendelkező norvég állami olajalap fontolóra veheti a részvényeinek eladását. A cikkben olvasható volt továbbá, hogy a MOL felügyelőbizottságának elnöke a korábban meglévő közel 55 ezer részvényéből 15 ezer darabot eladott. A cikk

185 15/2020. (VII. 8.) AB határozat [43] bek.

186 15/2020. (VII. 8.) AB határozat [46] bek.

187 15/2020. (VII. 8.) AB határozat [49] bek.

188 15/2020. (VII. 8.) AB határozat [53], [60], [63] bek.

189 15/2020. (VII. 8.) AB határozat rendelkező rész, 1. pont. A rémhírterjesztés tényállásának alkotmányos értelmezéséről bővebben, valamint a 18/2000. (VI. 6.) AB határozat és a 15/2020. (VII. 8.) $\mathrm{AB}$ határozat érvelésének összevetéséről lásd: Koltay András: A rémhírterjesztés büntethetőségének alkotmányosságáról. In Medias Res, 9. (2020), 2. 322-338. 
miatt az MNB mint hatóság hivatalból piacfelügyeleti eljárást indított, amely során megállapította, hogy a kiadó megsértette a tőkepiacról szóló 2001. évi CXX. törvény (Tpt.) piacbefolyásolást tilalmazó rendelkezését. A jogszabály értelmében piacbefolyásolásnak minősül a „megalapozatlan, félrevezető, hamis információ közlése, híresztelése, nyilvánosságra hozása vagy nyilvános közlése, feltéve, hogy az információt terjesztő személy az információ hamis vagy félrevezető mivoltának tudatában van, vagy az adott helyzetben elvárható gondossággal eljárva tudatában kellett volna lennie”.190 Azaz piacbefolyásoló lehet akár valós tényállítások közlése is. Az MNB határozatát a Fővárosi Közigazgatási és Munkaügyi Bíróság helybenhagyta, amely döntés megsemmisítése iránt a sajtótermék kiadója alkotmányjogi panaszt nyújtott be az AB-hoz - többek között a vélemény- és a sajtószabadság sérelmére hivatkozással.

$\mathrm{Az} A \mathrm{AB}$ az ügyben alkalmazott jogszabályi előírás kapcsán leszögezte, hogy a Tpt. említett rendelkezéseit megszorítóan kell értelmezni annak érdekében, hogy az ne korlátozza a sajtót demokratikus feladatainak ellátásában. ${ }^{191}$ Az eljárás tárgyát érintő cikket - témájára figyelemmel - a testület a közéleti vitákhoz szorosan kapcsolódó megszólalásnak tekintette, így azt a vélemény- és a sajtószabadság által fokozottan védett megnyilvánulások körébe tartozónak minősítette. ${ }^{192}$ A konkrét tartalom kapcsán az AB megállapította, hogy „[a] »megalapozatlan, félrevezető« jelleg megállapítására egyébként valós (tényekkel alátámasztott) információk kapcsán csak kivételesen, a sajtó rosszhiszemű eljárása esetén van lehetőség". ${ }^{193}$ Emellett pedig azt is leszögezte, hogy a félrevezető jelleggel kapcsolatos tudati állapot, illetve az elvárható gondosság feltételeit „szintén a szabad tájékoztatást támogató tartalommal, megszorítóan kell értelmezni”. ${ }^{194} \mathrm{Nem}$ az jelentett alkotmányossági problémát, hogy a bíróság tévesen minősítette a cikk tartalmát piacbefolyásolónak, hanem hogy elmulasztotta elvégezni a fenti mérlegelési műveletet. Az AB így a bíróság ítéletét - az MNB határozatát nem érintve -, annak alaptörvény-ellenességére tekintettel, megsemmisítette. ${ }^{195}$

190 Tpt. 202. $\$ d$ ) pont.

191 3/2015. (IV. 2.) AB határozat [26] bek.

192 3/2015. (IV. 2.) AB határozat [27] bek.

193 3/2015. (IV. 2.) AB határozat [28] bek.

194 3/2015. (IV. 2.) AB határozat [29] bek.

195 A határozat kritikájára nézve Lásd: Hörcherné Marosi Ildikó - Kormányos Zoltán:

Az Alkotmánybíróságnak a Fővárosi Közigazgatási és Munkaügyi Bíróság piacfelügyeleti bírsággal kapcsolatos ügyben hozott ítéletét megsemmisítő döntése. Jogesetek Magyarázata, 6. (2015), 3. 5-16. [az elemzés megítélésem szerint tévesen tekinti a sajtó által a konkrét esetben közzétett tartalmat kereskedelmi célú beszédnek (commercial speech), amelyre nem terjed ki a véleményszabadság teljes erejü védelme]. A döntéssel egyetértő elemzést Lásd: Török Bernát: Alkotmányjogi tesztek hálójában. A sajtószabadság esete a tőkepiaccal. In Fejes Zsuzsanna - Török Bernát (szerk.): Suum cuique: ünnepi tanulmányok Paczolay Péter 60. születésnapja tiszteletére. Szeged, Pólay Elemér Alapítvány, 2016. 671-684. 


\section{0. „Alvó” jogszabályok}

A 2012 utáni jogfejlődés egy sajátos jellegzetessége szerint bizonyos jogszabályokat nem, vagy csak igen csekély mértékben alkalmaznak a gyakorlatban. Ezen „alvó” jogszabályok egy része ráadásul átfedésben van más törvényi rendelkezésekkel. Ez a jogszabályi túlburjánzás a gyakorlati alkalmazás, illetve a joggyakorlat által kijelölt önálló tartalom hiányában zavaró.

Még az Alaptörvény 2013-as negyedik módosításáról is elmondható, hogy csak csekély jelentősége van az AB gyakorlatának alakulása tekintetében. A IX. cikk (4) bekezdése a módosítási tervezetet kísérő háttéranyag tanúsága szerint eleve „az Alkotmánybíróság korábbi gyakorlatát emeli alkotmányos szintre”.196 Az AB gyakorlata tehát a normaszöveg támogatása nélkül is kialakult már a módosítás elfogadásának idejére. A IX. cikk (5) bekezdése, ahogy említettem, a magánjogi gyűlöletbeszéd-tilalom alátámasztását szolgálta, amely viszont - függetlenül a Ptk.-beli rendelkezés problémáitól - az AB korábbi gyakorlata fényében szükségesnek tekinthető, ha a jogalkotó a törvényi rendelkezés alkotmányos jellegét biztosítani kívánja.

A rágalmazás és a becsületsértés tényállásai fényében redundánsnak tekinthető a képmás és a hangfelvétel speciális védelmét célzó két Btk.-beli bűncselekményi tilalom, a "Becsület csorbítására alkalmas hamis hang- vagy képfelvétel készítése” ${ }^{197}$ és a „Becsület csorbítására alkalmas hamis hang- vagy képfelvétel nyilvánosságra hozatala”. ${ }^{198}$ A gyakorlatban szintén csak elvétve fordul elő a Pp. speciális eljárása, a képmáshoz és a hangfelvételhez való jog érvényesítése érdekében indítható per lehetősége. ${ }^{199}$

$\mathrm{Az} \mathrm{AB}$ - és a polgári bíróságok - gyakorlata a Ptk. 2:44. \$-a nélkül is megfelelően biztosítja a közügyek vitájának szabadságát, illetve párhuzamosan szűkíti a közszereplők személyiségi jogainak érvényesülését. Azonban 2018-ban több fontos jogszabályváltozás is történt, amelyek alapvetően érintik a közügyek vitáinak szabadságát és a személyiségi jogok magánjogi érvényesülését. A magánélet védelméről szóló 2018. évi LIII. törvény $8 . \mathbb{S}(1)$ bekezdése szerint „[a] magánélet tiszteletben tartásához való jog célja, különösen a névviseléshez való jog, a személyes adatok, a magántitok, a képmás és hangfelvétel, a becsület és a jó hírnév védelme”. A 7. $\mathbb{\$}(2)$ bekezdése pedig rögzíti, hogy „[a] közéleti szereplő magán- és családi életét, valamint otthonát a közéleti szereplőnek nem minősülő személlyel azonos védelem illeti meg”. A két rendelkezés összeolvasásából arra is juthatunk, hogy a magánélethez való jog része a jó hírnévhez és a becsülethez, valamint a képmáshoz és a hangfelvételhez való jog, és a közéleti szereplők e jogai ugyanakkora terjedelműek, mint a magánszemélyeké. Ezen értelmezés azonban nem elfogadható, egyfelől azért, mert, ahogy az AB gyakorlatából láthattuk, e jogok érvényesülése tekintetében az elsődlegesen releváns

196 Háttéranyag az Alaptörvény negyedik módositásához. (é. n.) i. m. 17.

197 Btk. 226/A. \$.

198 Btk. 226/B. $\$$.

199 Pp. 502-504. . 
kategória nem a közéleti szereplő, hanem a közügy, másfelől pedig ugyanezen törvény módosította a Ptk. 2:44. \$-át, amely rögzíti a személyiségi jogok érvényesülésének csökkentett erejét a közügyek vitái tekintetében. Az új törvény mindazonáltal nem kreál olyan új tényállást, amely a közügyek vitáiban érvényesülő szólásszabadságmércékre hatással lehet, így a „jó hírnév” vagy a „magánélet” sérelme továbbra is csak a Ptk. tényállásai és az azok talaján formálódó $\mathrm{AB}$ - és bírósági gyakorlat figyelembevételével lesz megállapítható. (A családi élet, az otthon és a kapcsolattartás tiszteletben tartásához való jogok megsértésének ezzel szemben önálló tényállásait határozza meg a törvény.)

A Ptk. 2:44. $\mathbb{~ - a ́ n a k ~} 2018$ nyara óta hatályos rendelkezései szerint:

„(1) A közügyek szabad vitatását biztosító alapjogok gyakorlása a közéleti szereplő személyiségi jogainak védelmét szükséges és arányos mértékben, az emberi méltóság sérelme nélkül korlátozhatja; azonban az nem járhat a magán- és családi életének, valamint otthonának sérelmével.

(2) A közéleti szereplőt a közügyek szabad vitatásának körén kívül eső közléssel vagy magatartással szemben a nem közéleti szereplővel azonos védelem illeti meg. (3) Nem minősül közügynek a közéleti szereplő magán- vagy családi életével kapcsolatos tevékenység, illetve adat."

Az (1) bekezdés betoldott új szövegrésze („Azonban az nem járhat a magán- és családi életének, valamint otthonának sérelmével”) valószínűsíti, hogy a Ptk. szövegéből a magánélet fogalmának szűkítő értelmezése következik, azaz abban a jó hírnév és becsület joga nem foglaltatik benne. Az (1) bekezdés egészéből továbbra is az derül ki, hogy a közügyek vitáiban a hírnév-, a becsület-, a képmás- és a hangfelvétel-védelem csökkentett erővel érvényesül, és e vitákban közzétett, e jogokat hátrányosan érintő vélemények önmagukban e jellegük miatt nem jogsértők, azok a Ptk. korábbi gyakorlata és a szólásszabadság alkotmányos értelmezése szerint ítélendők meg. Az új (2) bekezdés lényegében a 7/2014. (III. 7.) AB határozatban rögzítettek egy részét kodifikálta, a közügyek vitatása körén kívül eső közlések tekintetében a közéleti szereplőknek is a magánszemélyekhez azonos erejű védelmet nyújtva. A szintén új (3) bekezdés esetében pedig különösen fontos, hogy azt a bíróságok majd az Alaptörvény IX. cikkében biztosított szólásszabadságra tekintettel értelmezzék: közéleti szereplő magánélete is lehet közérdeklődésre számot tartó, amennyiben összefüggésben van közéleti tevékenységével vagy érintkezést mutat valamely közüggyel.

A 2018. évi LIII. törvény olyan jogszabály, amelyet nehezen lehet megnyugtatóan elhelyezni a jogrendszer szövetében, elsősorban azért, mert jórészt megismétli az Alaptörvény, a Ptk. és az információs önrendelkezési jogról és az információszabadságról szóló 2011. évi CXII. törvény egyes rendelkezéseit, némely ponton kiegészítve azokat, a Ptk. szankciórendszerét alkalmazni rendelve a megsértése esetére. Értelmezése és önálló normatív tartalmának azonosítása a bíróságokra és majdan 
az $\mathrm{AB}$-ra marad; egyelőre e törvény is csendben várja, hogy rendelkezései a gyakorlatban életre keljenek.

\section{Következtetések}

A fenti áttekintésből néhány általános következtetés is levonható, annak ellenére, hogy az AB gyakorlata szükségszerüen folyamatosan formálódik. Talán elegendő idő telt már el ahhoz, hogy alapvető megközelítések kikristályosodjanak e gyakorlatból. Az alábbiakban ennek megfelelően bizonyos következtetések levonására teszek kísérletet.

- Az Alaptörvény szövege - ideértve a 2013-as negyedik módosítást is - csak mérsékelt hatást gyakorol az AB döntéseire. A vélemény- és a sajtószabadság alkotmányos tartalmát szükségszerüen továbbra is az $\mathrm{AB}$ döntései határozzák meg.

- A 7/2014. (III. 7.) AB határozat bátran tekinthető a véleményszabadság „alaphatározatának", amelynek általános tételei túlmutatnak a döntésben felmerült konkrét alkotmányossági kérdésen. Ez a döntés ráadásul a joggyakorlat számára is irányadó lehet, jóval inkább, mint a 2012 előtt, jobbára absztrakt normakontroll-eljárások során született, a véleményszabadság teoretikus meghatározását több tekintetben elvégző, de a gyakorlat számára alkalmazandó - és a bíróságokat kötelező - mércéket meghatározni nem képes AB-gyakorlat.

- Az emberi méltóság a véleményszabadság legfőbb és legáltalánosabb korlátja, amely a véleményszabadság bármely lehetséges korlátozásánál megfelelő súllyal figyelembe veendő szempont; az AB gyakorlata kerüli azon korábbi megközelítéseket, amelyek - például a büntetőjogi rágalmazás vagy a gyülöletbeszéd esetében - az emberi méltóság védelmét nem tekintették kellő alapnak a szóláskorlátozáshoz. Az AB gyakorlata a rivalizáló értékek közötti egyensúly megtalálását célozza, megítélésem szerint összességében - az egyes döntések közötti kisebb koherenciazavarok ellenére - sikerrel.

- Az alkotmányos véleményszabadság szempontja a magánjogi jogvitákban is figyelembe veendő, akkor is, ha a Ptk. szövege kifejezetten nem irányozza ezt elö. Erre a legkézenfekvőbb példát a rendőrképmásokat érintő ügyek adják, amelyekben az alkotmányos megközelítés a nyilvánosság tájékoztatásának érdekét mint a képmás felhasználásához való jogosulti hozzájárulás főszabálya alóli kivételt szinte „beleírta” a Ptk. képmásvédelmi szabályai közé. ${ }^{200}$

- A gyülöletbeszéd problematikájához kapcsolódó kérdésekben - önkényuralmi jelképek és népirtások tagadásának tilalma, illetve magánjogi gyülöletbeszéd-

200 Az alapjogok magánjogi jogviszonyokban való alkalmazhatóságának, azaz horizontális hatályának (Drittwirkung) kérdéséhez lásd: Gárdos-Orosz Fruzsina: Alkotmányos polgári jog? Az alapvetö jogok alkalmazása a magánjogi jogvitákban. Budapest, Dialóg Campus, 2011.; Téglási András: Az alapjogok hatása a magánjogi jogviszonyokban. In Tóth J. Zoltán (szerk.): A jog többrétegüsége. Budapest, Károli Gáspár Református Egyetem, 2020. 177-186. 
tilalom - az AB eltért a Btk.-beli „közösség elleni uszítás” tényálláshoz kapcsolódó korábbi mércéktől, a véleményszabadság érvényesülésének szűkülését eredményezve, ami az emberi méltóság fokozottabb védelmére tekintettel elfogadható.

- Egyes, önmagában talán kevésbé fontos, de szimbolikussá emelkedett kérdésben - mint például a rendőrképmások ügye - az AB és a bíróságok éles értelmezési vitákba bocsátkoztak, amelyek szükségszerủen az előbbi javára dőltek el. Ez a jelenség az alkotmányjogi panasz kiforrott gyakorlatának kialakulásához vezető elkerülhetetlen szülőfájdalmaknak, nem pedig az alkotmányos rendszer diszfunkciójának tekinthető.

- 2012 óta több, a gyakorlat számára nem alkalmazott, vagy egyéb jogszabályi rendelkezések mellett egyenesen szükségtelennek tekinthető törvényi szabály született, beleértve a Ptk. jelentős újítását, a közügyek vitáinak szélesebb szabadságát előirányzó 2:44. \$-t. Az AB és a bíróságok által nem alkalmazott, más rendelkezésekkel átfedésben lévő szabályok léte inkább zavaróan hat.

Megítélésem szerint minden kisebb-nagyobb - és a fentiekben jelzett - következetlenség vagy egyéb probléma ellenére, a vizsgált évek alatt jelentős előrelépés történt a véleményszabadság alkotmányos tartalmának meghatározásában. A közügyek vitái úgy maradtak széles körben szabadok, hogy közben az emberi méltóság sem maradt védtelen. A bíróságok több esetkör - elsősorban a személyiségi jogok védelme - tekintetében világos mércéket kaptak, és a gyakorlat olyan kérdéseket is érint - mint a híresztelés vagy a képmásvédelem -, amelyekről korábban az AB nem szólhatott. Az AB 2012 óta úgy újította meg és tette a gyakorlat számára is alkalmazhatóvá a véleményszabadsággal összefüggő gyakorlatát, hogy a maga tevékenységét az 1992 óta eltelt két évtizedes gyakorlatára alapozta, nem habozván eltérni attól, ha úgy szükséges, még ha nem is tette minden esetben könnyen felismerhetővé az eltérést.

Záró következtetésemben egyetértésemet fejezem ki Schiffer Andrással, aki szerint $\mathrm{az} A B$ döntései által érintett problémakörök tekintetében $\mathrm{az} A B$,jogfejlesztő tevékenysége stabilizálta a vélemény- és sajtószabadság helyzetét. Ennyiben - paradox módon - 2012 óta a vélemény- és sajtószabadság alkotmányos biztosítékai még szilárdabbá is váltak." ${ }^{201}$ A vizsgált időszakban folyamatosan tapasztalható polarizált közéleti-politikai viták forgatagában ez sokszor nem kellő mértékben tudatosuló, másszor egyenesen eltagadott, de a demokratikus nyilvánosság számára ezzel együtt is mindenképpen örömteli fejlemény.

201 Schiffer András: A véleményszabadság alkotmánybírósági esetjoga a megváltozott közjogi környezetben. Alkotmánybirósági Szemle, (2018), 1. 48. 


\section{Irodalomjegyzék}

Badó Katalin - Lovassy Ádám - Téglási András: Az Alkotmánybíróság választásokkal kapcsolatos joggyakorlata (1990-2017). In Téglási András (szerk.): Tanulmányok a választójog, a választási rendszerek és a népszavazás aktuális kérdéseiről. A Választás és Demokrácia Ludovika Kutatócsoport kutatási eredményei (2017-2018). Budapest, Dialóg Campus, 2019. 303-470.

Balogh Adrienn - Hegyi Szabolcs: A Kúria jogegységi határozata a közhatalmat gyakorlókról készült képmás és hangfelvétel nyilvánosságáról. Közszereplö-e a nyilvános helyen szolgálatot teljesítő rendőr? Jogesetek Magyarázata, 5. (2014), 2. 29-35.

Balogh Éva: Egy lépést hátra. A magyar Alkotmánybíróság döntése az internetes hozzászólásokért való felelősségről. Pro Futuro, 5. (2015), 1. 142-150. Online: https://doi.org/10.26521/Profuturo/2015/1/5466

Balogh Éva: A megkülönböztetés művészete: bírói mérlegelés a közszereplőkkel kapcsolatos közlések szabadsága kapcsán. Fundamentum, (2016), 1. 22-38.

Balogh Éva: Alkotmánybíróság útvesztőben. Fundamentum, (2018), 2-3. 80-99.

Boronkay Miklós: A képmáshoz és a hangfelvételhez füződő jog. In Csehi Zoltán - Koltay András - Navratyil Zoltán (szerk.): A személyiség és a média a polgári és a büntetőjogban. Budapest, Wolters Kluwer, 2014. 11-56.

Bragyova András: Szólásszabadság és sajtószabadság az internetes kommentek példáján. In Fejes Zsuzsanna - Török Bernát (szerk.): Suum cuique: Ünnepi tanulmányok Paczolay Péter 60. születésnapja tiszteletére. Szeged, Pólay Elemér Alapítvány, 2016. 473-490.

Grad-Gyenge Anikó: Commentare necesse est - néhány gondolat az Alkotmánybíróság „kommenthatározatáról". Glossa Iuridica, 2. (2015), 1-2. 122-142.

Botos Mihály Bálint - Gál Andor: Az Alkotmánybíróság határozata a véleményszabadság büntetőjogi korlátját tévesen megállapító bírósági döntések megsemmisítéséről: A valóságbizonyítás formalizált eljárásban történő lefolytatása mint a szólásszabadsághoz való jog érvényesülésének követelménye. Jogesetek Magyarázata, 11. (2020), 1-2. 7-14.

Fejes Erik: A rendvédelmi testületek hivatásos állományába tartozó személyek képmáshoz füződő jogának korlátozhatósága. In Görög Márta - Menyhárd Attila - Koltay András (szerk.): A személyiség és védelme. Az Alaptörvény VI. cikkelyének érvényesülése a magyar jogrendszeren belül. Budapest, ELTE ÁJK, 2017. 143-161.

Gárdos-Orosz Fruzsina: Alkotmányos polgári jog? Az alapvető jogok alkalmazása a magánjogi jogvitákban. Budapest, Dialóg Campus, 2011.

Gárdos-Orosz Fruzsina: Az új polgári jogi gyülöletbeszéd-szabályozásról. Fundamentum, 17. (2013), 3. 21-38.

Gárdos-Orosz Fruzsina - Pap András László: Gondolatok a gyülöletbeszéd polgári jogi szabályozásának jogi és jogpolitikai környezetéről. Állam-és Jogtudomány, 55. (2014), 2. 3-26.

Görög Márta: A magánélethez való jog mint a személyiségi jog újabb, magánjogi kódexben nevesített vonatkozása. In Balogh Elemér (szerk.): Számadás az Alaptörvényről. Budapest, Magyar Közlöny Lap- és Könyvkiadó, 2016. 51-63.

Háttéranyag az Alaptörvény negyedik módositásához Online: tinyurl.com/5eycz72t

Hörcherné Marosi Ildikó - Kormányos Zoltán: Az Alkotmánybíróságnak a Fővárosi Közigazgatási és Munkaügyi Bíróság piacfelügyeleti bírsággal kapcsolatos ügyben hozott ítéletét megsemmisítő döntése. Jogesetek Magyarázata, 6. (2015), 3. 5-16.

Juhász Imre: Fiat libertas, pereat mundus? Alkotmánybírósági Szemle, (2016), 1. 88-107. 
Kazai Viktor Zoltán: Strasbourgi manifesztum a liberális demokrácia védelmében. Fundamentum, 19. (2015), 2-3. 95-106.

Klein Tamás: A tárhelyszolgáltató „omnipotens” felelőssége mint alkotmányjogi problematika: A harmadik személy tartalmáért való szolgáltatói felelősség az interneten. In Koltay András - Török Bernát (szerk.): Sajtószabadság és médiajog a 21. század elején 3. Budapest, Wolters Kluwer, 2016. 349-374.

Koltay András: A „clear and present danger” elv fordulatos története az Egyesült Államokban és Magyarországon. Magyar Jog, 56. (2009), 7. 418-423.

Koltay András: Az Alkotmány új 61. \$-a. A vélemény- és a sajtószabadság új ruhában. Közjogi Szemle, (2010), 3. 1-9.

Koltay András: A gyülöletbeszéd korlátozása a magyar jogrendszerben. In Koltay András (szerk.): A gyülöletbeszéd korlátozása Magyarországon. Alkotmányos és jogalkalmazói megközelitések, európai kitekintéssel. Budapest, CompLex, 2013. 157-172.

Koltay András: A nagy magyar gyülöletbeszéd-vita: a „gyülöletre uszítás” alkotmányos mércéjének azonosítása felé. Állam- és Jogtudomány, 54. (2013), 1-2. 91-124.

Koltay András: Az Alkotmánybíróság határozata az internetes kommentek polgári jogi megítéléséről. Jogesetek Magyarázata, 6. (2015), 1. 9-21.

Koltay András: Dorian Gray képmásához való jog: a művészet szabadságának önálló alapjogi jellegéről. In Koltay András - Török Bernát (szerk.): Sajtószabadság és médiajog a 21. század elején 3. Budapest, Wolters Kluwer, 2016. 53-99.

Koltay András: Az „általános személyiségi jog” azonosítása felé. Alkotmányjogi, magánjogi és büntetőjogi vizsgálódás. In Koltay András - Török Bernát (szerk.): Sajtószabadság és médiajog a 21. század elején 4. Budapest, Wolters Kluwer, 2017. 267-296.

Koltay András: A gyülölet magánjogi korlátozása. A Ptk. és a gyakorlat kezdeti tapasztalatai. In Molnár Gábor Miklós - Koltay András (szerk.): Bonus iudex. Ünnepi tanulmányok Varga Zoltán 70. születésnapja alkalmából. Budapest, Kúria - Pázmány Press, 2018. 197-225.

Koltay András: A rémhírterjesztés büntethetőségének alkotmányosságáról. In Medias Res, 9. (2020), 2. 322-338.

Koltay András - Polyák Gábor: Az Alkotmánybíróság határozata a médiaszabályozás egyes kérdéseiről. Jogesetek Magyarázata, 3. (2012), 1. 11-48.

Menyhárd Attila: A magánélethez való jog a szólás- és médiaszabadság tükrében. In Csehi Zoltán - Koltay András - Navratyil Zoltán (szerk.): A személyiség és a média a polgári és a büntetőjogban. Budapest, Wolters Kluwer, 2014. 177-226.

Mészáros Ádám Zoltán: Szimbolikus szólás kontra dologrongálás. Azaz a véleménynyilvánítás szabadsága és a tulajdonhoz való jog határvitája büntetőjogi szempontból. Jogtudományi Közlöny, 75. (2020), 2. 74-78.

Molnár Hella: A közéleti szereplők személyiségi jogainak védelme. In Görög Márta - Menyhárd Attila - Koltay András (szerk.): A személyiség és védelme. Az Alaptörvény VI. cikkelyének érvényesülése a magyar jogrendszeren belül. Budapest, ELTE ÁJK, 2017. 15-32.

Navratyil Zoltán: Az emberi méltóság magánjogi szerepe és a véleménynyilvánítás szabadsága. In Koltay András - Török Bernát (szerk.): Sajtószabadság és médiajog a 21. század elején 3. Budapest, Wolters Kluwer, 2016. 121-152.

Papp János Tamás: A rendőrök képmáshoz való jogának kérdése. In Görög Márta - Menyhárd Attila - Koltay András (szerk.): A személyiség és védelme. Az Alaptörvény VI. cikkelyének érvényesülése a magyar jogrendszeren belül. Budapest, ELTE ÁJK, 2017. 119-142. 
Papp János Tamás: Az Alkotmánybíróság két újabb határozata a rendvédelmi dolgozók képmásának nyilvánosságáról. Jogesetek Magyarázata, 7. (2016), 4. 5-11.

Pokrócos György: A rendőr képmásának nyilvánosságra hozatala. Belügyi Szemle, 67. (2019), 2. 89108. Online: https://doi.org/10.38146/BSZ.2019.2.6

Sándor István: A képmáshoz való jog és a sérelemdíj bírósági gyakorlatának tendenciái. Belügyi Szemle, 68. (2020), 4. 53-69. Online: https://doi.org/10.38146/BSZ.2020.4.2

Schiffer András: A véleményszabadság alkotmánybírósági esetjoga a megváltozott közjogi környezetben. Alkotmánybírósági Szemle, (2018), 1. 34-48.

Sepsi Tibor: No comment? Az internetes hozzászólásokért való jogi felelősség. Fundamentum, (2015), 4. 106-110.

Smuk Péter: Ostrom vagy felújítás alatt? A véleményszabadság új határai. Közjogi Szemle, 6. (2013), 2. 25-34.

Smuk Péter: Az Emberi Jogok Európai Bíróságának határozata az Országgyűlés fegyelmi intézkedéseiről. Jogesetek Magyarázata, 6. (2015), 1. 63-68.

Smuk Péter: Az önkényuralmi rendszerek jelképei és a használatukat tiltó jogi szankciók rendszere. In Medias Res, 8. (2019), 2. 230-252.

Somody Bernadette: A rendőrarcképmás-ügy mint az alapjogi ítélkezés próbája. Fundamentum, 20. (2016), 1. 103-112.

Szente Zoltán: Emberi jogok-e a parlamenti képviselői jogok? A képviselői szólásszabadság alkotmányjogi jellegéről. Állam-és Jogtudomány, 56. (2015), 2. 74-90.

Szigeti Tamás - Simon Éva: A hozzászólás szabadsága: a közvetítő szolgáltatói felelősség aktuális kérdéseiről. Fundamentum, 20. (2016), 2-4. 113-124.

Szomora Zsolt: Az emberi méltóság és egyes alapvető jogok elleni bűncselekmények. In Karsai Krisztina (szerk.): Kommentár a Büntetö törvénykönyvhöz. Budapest, CompLex, 2013. 451-481.

Szomora Zsolt: Az Alkotmánybíróság büntetőítéletet megsemmisítő döntése a közszereplők büntetőjogi becsületvédelméről. Jogesetek Magyarázata, 5. (2014), 3. 13-22.

Szomora Zsolt: Az alkotmányos követelmények hivatkozási tipológiája becsületsértési és rágalmazási ügyekben hozott büntetőítéletekben. Jogtudományi Közlöny, 69. (2014), 10. 469-476.

Szomora Zsolt: A véleményszabadság büntetőjogi korlátai az Alaptörvény hatályba lépése után, különös tekintettel a becsületvédelemre. In Balogh Elemér (szerk.): Számadás az Alaptörvényröl. Budapest, Magyar Közlöny Lap- és Könyvkiadó, 2016. 521-537.

Téglási András: Véleményszabadság vs. emberi méltóság - Egy rejtélyes alaptörvény-módosítás nyomában. Acta Humana, 3. (2015), 6. 25-47.

Téglási András: Az alapjogok hatása a magánjogi jogviszonyokban. In Tóth J. Zoltán (szerk.): A jog többrétegüsége. Budapest, KGRE, 2020. 177-186.

Tóth J. Zoltán: Az önkényuralmi jelképek használata mint a véleménynyilvánítási szabadság korlátja? Jogelméleti Szemle, (2013), 2. 178-196.

Tóth J. Zoltán: A véleménynyilvánítási szabadság érvényesülése és érvényesítése a választási eljárásokban: az Alkotmánybíróság gyakorlata a választási ügyben hozott bírói döntéssel szembeni alkotmányjogi panasz alapján indult ügyekben. Jogtudományi Közlöny, 71. (2016), 1. 1-18.

Tóth J. Zoltán: A büntetőjogi rágalmazás és becsületsértés. Budapest, Médiatudományi Intézet, 2017.

Tóth J. Zoltán: Rendőrképmás: sajtószabadság és képmáshoz való jog a polgári jogi és az alapjogi jogosultságok keresztútján. Pro Futuro, 7. (2017), 2. 110-128. Online: https://doi.org/10.26521/ Profuturo/2017/2/4766 
Török Bernát: A közlések alkotmányos alapértéke a szólásszabadság magyar koncepciójában. In Koltay András - Török Bernát (szerk.): Sajtószabadság és médiajog a 21. század elején 2. Budapest, Wolters Kluwer, 2015. 203-224.

Török Bernát: Alkotmányjogi tesztek hálójában. A sajtószabadság esete a tőkepiaccal. In Fejes Zsuzsanna - Török Bernát (szerk.): Suum cuique: Ünnepi tanulmányok Paczolay Péter 60. születésnapja tiszteletére. Szeged, Pólay Elemér Alapítvány, 2016. 671-684. 